VILNIAUS GEDIMINO TECHNIKOS UNIVERSITETAS

Indrè SLAPIKAITÉ

\title{
IMONIŲ SOCIALINĖS ATSAKOMYBĖS VERTINIMAS FINANSUOTOJO POŽIŪRIU
}

DAKTARO DISERTACIJA

SOCIALINIAI MOKSLAI, EKONOMIKA (04S)

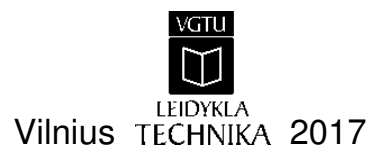


Disertacija rengta 2012-2017 metais Vilniaus Gedimino technikos universitete.

Vadovas

doc. dr. Rima TAMOŠIŪNIENĖ (Vilniaus Gedimino technikos universitetas, ekonomika - 04S).

Vilniaus Gedimino technikos universiteto Ekonomikos mokslo krypties disertacijos gynimo taryba:

\section{Pirmininkas}

prof. dr. Jelena STANKEVIČIENE (Vilniaus Gedimino technikos universitetas, ekonomika-04S).

\section{Nariai:}

prof. habil. dr. Romualdas GINEVIČIUS (Vilniaus Gedimino technikos universitetas, ekonomika - 04S),

dr. Tatjana POLAJEVA (Talino technologijos universitetas, ekonomika 04S),

prof. dr. Dalia ŠTREIMIKIENĖ (Vilniaus universitetas, ekonomika - 04S), prof. dr. Manuela TVARONAVIČIENE (Vilniaus Gedimino technikos universitetas, ekonomika - 04S).

Disertacija bus ginama viešame Ekonomikos mokslo krypties disertacijos gynimo tarybos posėdyje 2017 m. birželio 9 d. 13 val. Vilniaus Gedimino technikos universiteto senato posèdžių salëje.

Adresas: Saulètekio al. 11, LT-10223 Vilnius, Lietuva.

Tel.: (8 5) 274 4956; faksas (8 5) 270 0112; el. paštas doktor@vgtu.lt

Pranešimai apie numatomą ginti disertaciją išsiųsti 2017 m. gegužès $8 \mathrm{~d}$.

Disertaciją galima peržiūrèti VGTU talpykloje http://dspace.vgtu.lt ir Vilniaus Gedimino technikos universiteto bibliotekoje (Sauletekio al. 14, LT-10223 Vilnius, Lietuva), Lietuvos socialinių tyrimų centro bibliotekoje (A. Goštauto g. 9, LT-01108 Vilnius) ir Lietuvos agrarinès ekonomikos institute (V. Kudirkos g. 18, LT-03101, Vilnius).

VGTU leidyklos TECHNIKA 2017-031-M mokslo literatūros knyga http://leidykla.vgtu.lt

ISBN 978-609-476-025-9

(C) VGTU leidykla TECHNIKA, 2017

(C) Indrè Slapikaité, 2017

Indre.slapikaite@gmail.com 
VILNIUS GEDIMINAS TECHNICAL UNIVERSITY

Indrè SLAPIKAITÉ

\section{EVALUATION OF CORPORATE SOCIAL RESPONSIBILITY FROM THE FUNDER'S POINT OF VIEW}

DOCTORAL DISSERTATION

SOCIAL SCIENCES,

ECONOMICS (04S)

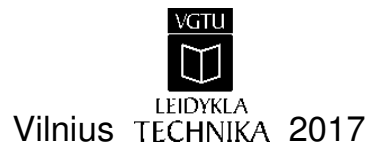


Doctoral dissertation was prepared at Vilnius Gediminas Technical University in 2012-2017.

\section{Supervisor}

Assoc. Prof. Dr Rima TAMOŠIŪNIENĖ (Vilnius Gediminas Technical University, Economics - 04S).

The Dissertation Defence Council of Scientific Field of Economics of Vilnius Gediminas Technical University:

\section{Chairman}

Prof. Dr Jelena STANKEVIČIENE (Vilnius Gediminas Technical University, Economics - 04S).

\section{Members:}

Prof. Habil. Dr Romualdas GINEVIČIUS (Vilnius Gediminas Technical University, Economics - 04S),

Dr Tatjana POLAJEVA (Tallinn University of Technology, Economics 04S),

Prof. Dr Dalia ŠTREIMIKIENE (Vilnius University, Economics - 04S),

Prof. Dr Manuela TVARONAVIČIENE (Vilnius Gediminas Technical University, Economics - 04S).

The dissertation will be defended at the public meeting of the Dissertation Defence Council of Economics in the Senate Hall of Vilnius Gediminas Technical University at 1 p. m. on 9 June 2017.

Address: Saulètekio al. 11, LT-10223 Vilnius, Lithuania. Tel.: +370 5274 4956; fax +370 5270 0112; e-mail: doktor@vgtu.lt

A notification on the intend defending of the dissertation was send on 8 May 2017.

A copy of the doctoral dissertation is available for review at VGTU repository http://dspace.vgtu.lt and at the Library of Vilnius Gediminas Technical University (Saulètekio al. 14, LT-10223 Vilnius, Lithuania), at the Library of Lithuanian Social Research Center (A. Goštauto g. 9, LT-01108 Vilnius) and Lithuanian Institute of Agrarian Economics (V. Kudirkos g. 18, LT-03101, Vilnius). 


\section{Reziumè}

Disertacijoje nagrinėjmas įmonių socialinès atsakomybès vertinimas finansuotojo požiūriu. Literatūros analizė atskleidè, jog šiuo metu įmonių finansiné atsakomybė yra vienas svarbiausių klausimų finansuotojui, i kuri reikia atsižvelgti vertinant finansuojamų įmonių riziką ir priimant sprendimus dėl tokių imonių finansavimo. Tačiau, nors praktikoje pastebima, jog bankai vis labiau linkę taikyti socialinès atsakomybès aspektus savo veikloje, tačiau jų finansuojamu įmonių socialinès atsakomybès vertinimas yra vis dar gana ribotas ir neinformatyvus. Todèl šiame darbe sprendžiama mokslinė problema - kaip reikètų vertinti įmonių socialinę atsakomybę finansuotojo atžvilgiu.

Pagrindinis disertacijos tikslas yra sukurti ịmonių socialinès atsakomybės kompleksinio vertinimo sistemą, skirtą finansuotojui, bei patikrinti jos tinkamumą vertinant realias ịmones. Darbe sprendžami tokie pagrindiniai uždaviniai: siekiama atskleisti ịmonių socialinès atsakomybės vertinimos svarbą tvarios bankininkystės ir ekonomikos raidos kontekste, išnagrinėti įmonių socialinès atsakomybès sąvokos sampratą tvarios plètros ir darnaus vystymosi sąvokų kontekste, apžvelgti naudojamas įmonių socialinès atsakomybės kriterijų sąrankas bei vertinimo metodus, suformuoti i̇monių socialinès atsakomybės kompleksinio vertinimo sistemos teorini pagrindą bei sumodeliuoti pačią sistemą. Galiausiai sistemos patikimumą patikrinti vertinant realias įmones.

Disertaciją sudaro ịvadas, trys skyriai, skyrių ir bendrosios išvados, literatūros šaltinių sąrašas, autorès publikacijų disertacijos tema sąrašas bei disertacijos priedai. İvade yra aptariama tiriamoji problema, atskleidžiamas darbo aktualumas, suformuluojamas tyrimų objektas, darbo tikslas bei uždaviniai, aprašoma tyrimų metodika, atskleidžiamas darbo mokslinis naujumas bei darbo praktiné reikšmè. Pirmame skyriuje analizuojama i̇monių socialinès atsakomybės vertinimo svarba bankų veiklos ir ekonomikos kontekste, pateikiama įmonių socialinès atsakomybès sampratos apžvalga, apžvelgiamos naudojamos įmonių socialinès atsakomybès kriterijų sąrankos bei vertinimo metodai. Galiausiai suformuojamas teorinis pagrindas įmonių socialinès atsakomybès kompleksinio vertinimo sistemai sudaryti. Antrame skyriuje, pasitelkiant daugiakriterinius vertinimo metodus, atliekiamas teorinis įmonių socialinès atsakomybès kompleksinio vertinimo sistemos modeliavimas. Trečiame skyriuje praktiškai suformuojama galutinè įmonių socialinès atsakomybès kompleksinio vertinimo sistema bei patikrinama trijų realių ịmonių pagrindu. Disertacijos pabaigoje pateikiamos bendrosios viso darbo išvados.

Disertacijos tema paskelbti 7 moksliniai straipsniai, perskaityti 3 pranešimai mokslinèse konferencijose. 


\section{Abstract}

The doctoral dissertation examines evaluation of corporate social responsibility from the funder's point of view. The literature analysis revealed that today coporate social responsibility is one of the most important subjects that needs to be taken into account while assessing the risk and making the decisions for the funded companies. Although it has been noticed in the practice that funders (banks) tend to integrate sustainability principles into their activity, the evaluation of funded companies' corporate social responsibility is still rather limited and non-informative. Therefore, this paper aims to solve such scientific problem - how corporate social responsibility should be evaluated from the funder's point of view.

The primary aim of the present dissertation is to create a complex evaluation system of corporate social responsibility and practically apply for real companies evaluation. The paper pursues the following main objectives: to reveal the importance of corporate social responsibility evaluation in the context of sustainable banking and economic development, to analyze and summarize the concept of corporate social responsibility in the context of sustainable development, to review the current criterias of coporate social responsibility and its evaluation methods, to form a theoretical background for CSR complex evaluation system and afterwards to form the system practically. Finally, to apply the CSR complex evaluation system in order to evaluate real companies.

The present dissertation consists of the introduction, three chapters, chapters' and general conclusions, references and the list of scientific publications by the author on the topic of the dissertation. The introduction includes the problem, reveals the relevance of the dissertation, describes the object of the research, formulates the aim and objectives, states the research methodology, highlights the scientific novelty and practical value of the thesis. The first chapter analyses the importance of corporate social responsibility in the context of banking and economic development, reviews the criterias and evaluation methods of corporate social responsibility and states a theoretical background for the further formation of CSR complex evalution system. The second chapter includes multiple criteria decision-making methods that are used to theoretically form a CSR complex evaluation system. In the third chapter CSR complex evaluation system is formed practically and applied for evaluating real companies. Finally, the overall findings are summarized at the end of the thesis.

There has been published 7 scientific articles on the topic of the present dissertation and 3 presentations were made at scientific conferences. 


\section{Žymëjimai}

\section{Santrumpos}

AHP - Analitinès hierarchijos procesas (angl. Analytic Hierarchy Process); ALRA - Alinkosauginius leidimus reguliuojanti agentūra (angl. Environmental Permitting Regulations arba EPR);

AVS - Aplinkosaugos vadybos sistema (angl. Environmental Management Systems arba EMS);

AVI - Aplinkosauginès veiklos indeksas (angl. Environmental Performance Index arba EPI);

COPRAS - daugiatikslis kompleksinio proporcingo ịvertinimo metodas (ang. Method of Multiple Criteria Complex Proportional Assessment);

DCF - diskontuoti pinigu srautai (angl. discounted cash flow);

EAA - Europos aplinkos agentūra (angl. European Environment Agency arba EEA); 
EBITDA - pelnas iki palūkanų mokèjimo, mokesčių ir nusidèvèjimo (angl. Earnings before interest, taxes, depreciation and amortization);

ESG - aplinkosauginiai, socialiniai ir valdymo kriterijai (angl. environmental, social and governance);

EVAS - Ekovadybos ir audito sistema (angl. Eco Management and Audit Scheme arba EMAS);

IRR - vidinè grąžos norma (angl. Internal Rate of Return);

ISA - įmonių socialinè atsakomybè;

ISV - įmonių socialinė veikla (angl. Corporate Social Performance arba CSP);

JT AAA - Jungtinių Tautų aplinkos apsaugos agentūra (angl. United Nations Environmental Protection Agency arba UN EPA);

JTO - Jungtinių Tautų Organizacija;

JT Pasaulinis susitarimas - Jungtinių Tautų Pasaulinis susitarimas (angl. UN Global Compact);

LAAA - Licencijuotų ir atestuotų apskaitininkų asociacija (angl. Association of Chartered Certified Accountants arba ACCA);

LAVA - Lietuvos atsakingo verslo asociacija;

NAVA - Nacionalinio atsakingo verslo apdovanojimas;

NAVİT - Nacionalinio atsakingo verslo įmonių tinklas;

NPV - grynoji dabartinè vertè (angl. Net Present Value);

PARI - Pasaulinė ataskaitų rengimo iniciatyva (angl. Global Reporting Initiative arba GRI);

ROA - turto grąža (angl. Return on Assets);

ROE - nuosavo kapitalo grąža (angl. Return on assets);

ROI - investicinė grąža (angl. Return on Investment);

ROS - pardavimų grąža (angl. Return on Sales);

SAW - paprastasis adityvus svorių metodas (angl. Simple Additive Weighting);

SSGG - stiprybių, silpnybių, grèsmių ir galimybès analizė (angl. SWOT);

TBL - Trijų ramsčių teorija (angl. Triple Bottom Line);

TOPSIS - artumo idealiajam taškui metodas (angl. Technique for the Order

Preference by Similarity to Ideal Solution);

TSA - Tarptautinè socialinè atskaitomybè (angl. Social Accountability

International arba SAI);

VIKOR - kompromisinis rangavimo metodas (angl. Compromise Ranking Method); VS - visų rodiklių vienetų sumos metodas. 


\section{Turinys}

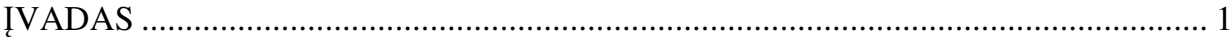

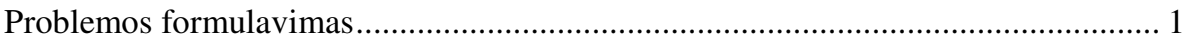

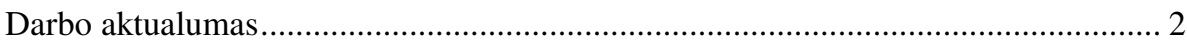

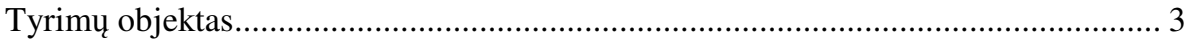

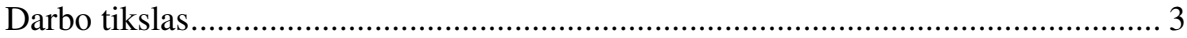

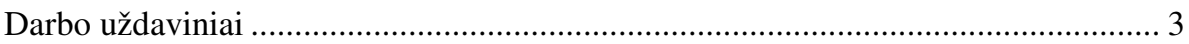

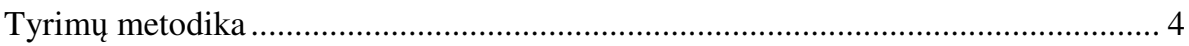

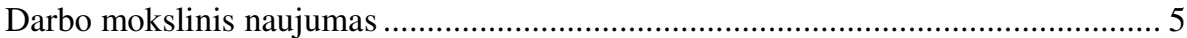

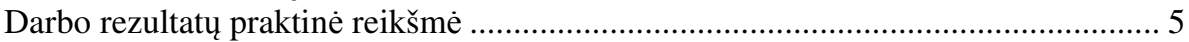

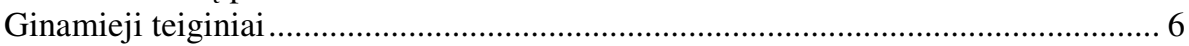

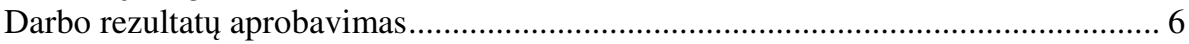

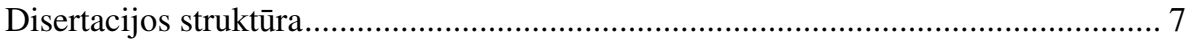

1. İMONIŲ SOCIALINĖS ATSAKOMYBĖS VERTINIMO

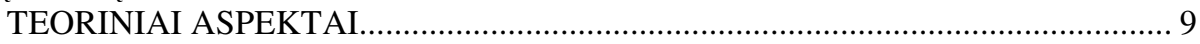

1.1. İmonių socialinès atsakomybès vertinimo svarba finansuotojui ....................... 10

1.2. İmonių socialinès atsakomybès atsiradimo prielaidos, istorinè raida bei

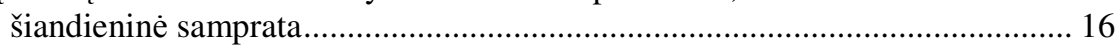

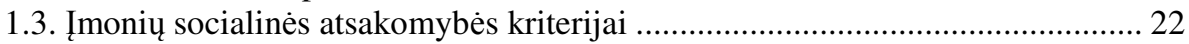

1.3.1. Pagal Lietuvos ir užsienio institucijas .................................................. 23

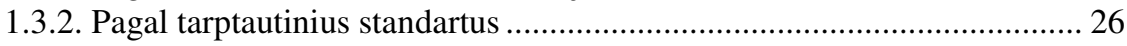

1.4. İmonių socialinès atsakomybės vertinimas .................................................... 29 
1.5. İmonių socialinès atsakomybès kompleksinio vertinimo sistemos teorinio

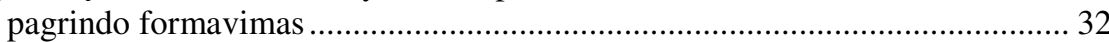

1.5.1. Sąsaja su įmonès veiklos finansiniais rezultatais.................................... 32

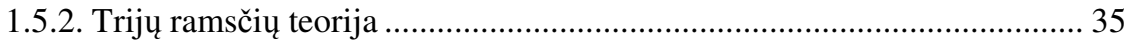

1.5.3. Finansinių rodiklių integravimas ị vertinimo sistemą.............................. 38

1.6. Pirmo skyriaus išvados ir disertacijos uždavinių formulavimas......................... 40

2. İMONIŲ SOCIALINĖS ATSAKOMYBĖS KOMPLEKSINIO VERTINIMO SISTEMOS TEORINIS MODELIAVIMAS …………………........................... 43

2.1. İmonių socialinès atsakomybès kompleksinio vertinimo sistemos algoritmo

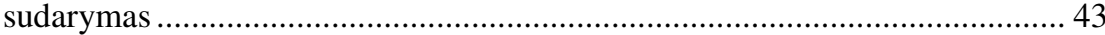

2.2. Lietuvoje veikiančiu komercinių bankų brandumo lygio socialinès

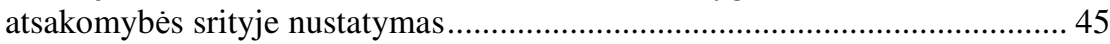

2.3. Imonių socialinès atsakomybès vertinimo kriterijų sąrankos sudarymas ...........50

2.4. İmonių socialinès atsakomybès kompleksinio vertinimo sistemos teorinis modeliavimas pasitelkiant daugiakriterinio vertinimo metodus ...................... 54

2.4.1. Sistemą sudarančių kriterijų reikšmingumų nustatymas taikant AHP

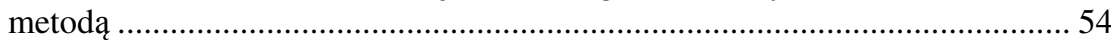

2.4.2. Kitų daugiakriterinio vertinimo metodų integravimas ir jų

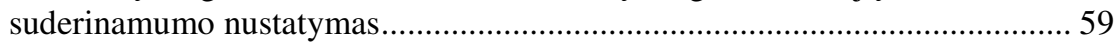

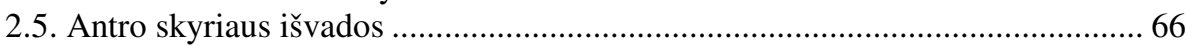

3. İMONIŲ SOCIALINĖS ATSAKOMYBĖS KOMPLEKSINIO VERTINIMO SISTEMOS PRAKTINIS MODELIAVIMAS IR PRITAIKYMAS .......................... 69

3.1. Galutinès įmonių socialinès atsakomybès kompleksinio vertinimo sistemos

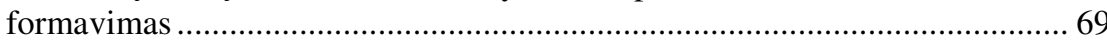

3.2. Sistemos praktinis patikrinimas................................................................... 74

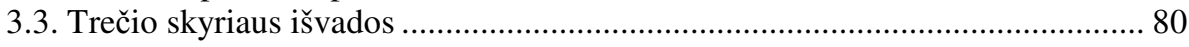

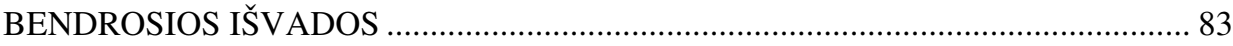

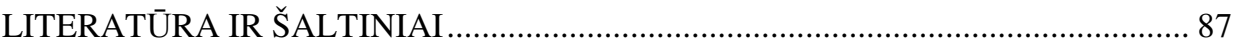

AUTORĖS MOKSLINIŲ PUBLIKACIJŲ DISERTACIJOS TEMA SĄRAŠAS ...... 101

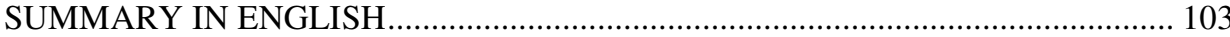

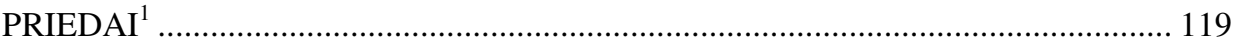

A priedas. Detalizuota finansinių kriterijų grupé .................................................... 120

B priedas. Komercinių bankų socialinès atsakomybès brandumo lygių

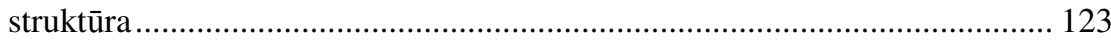

C priedas. Komercinių bankų Lietuvoje brandumo lygio nustatymas..................... 125

D priedas. Detalizuoti sistemos kriterijai ................................................................ 128

E priedas. Sistemos kriterijų reikšmingumo nustatymas ekspertinio vertinimo

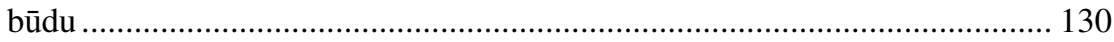

F priedas. Kriterijų reikšmingumų nustatymo pavyzdys ....................................... 135

${ }^{1}$ Priedai pateikiami pridètoje kompaktinejje plokštelèje. 
G priedas. Kriterijų reikšmingumų skaičiavimas pagal AHP metodą ..................... 136

$\mathrm{H}$ priedas. Sistemos praktinis pritaikymas ............................................................. 138

I priedas. Trijų įmonių socialinės atsakomybės daugiakriterinio vertinimo

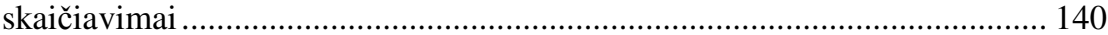

Y priedas. Ekspertinio vertinimo duomenų rangavimas......................................... 144

J priedas. Disertacijos autoriaus sąžiningumo deklaracija...................................... 147

K priedas. Bendraautorių sutikimai teikti publikacijų medžiagą disertacijoje ....... 148

L priedas. Autoriaus mokslinių publikacijų disertacijos tema kopijos .................... 150 



\section{Contents}

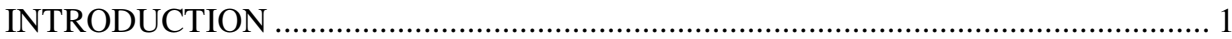

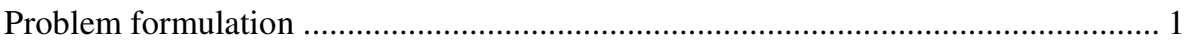

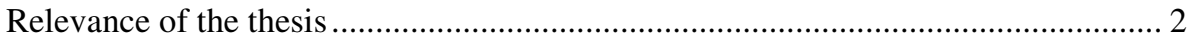

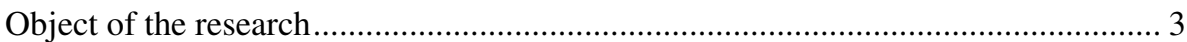

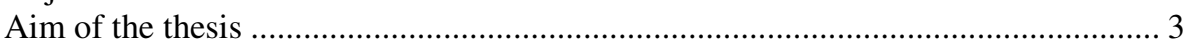

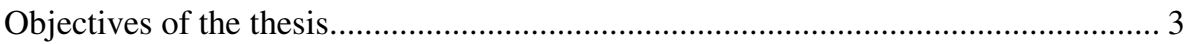

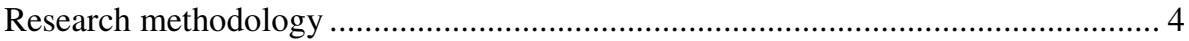

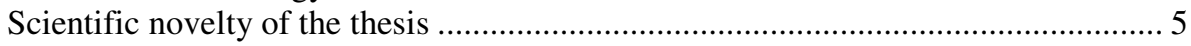

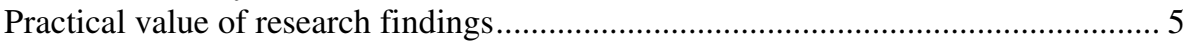

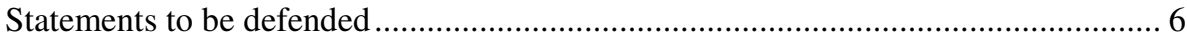

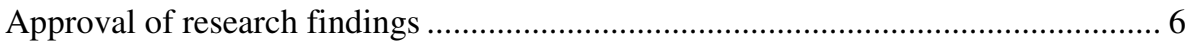

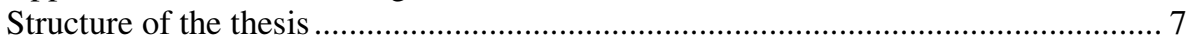

1. THEORETICAL ASPECTS OF EVALUATION OF CORPORATE SOCIAL

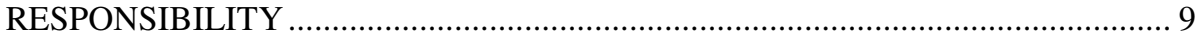

1.1. Importance of corporate social responsibility evaluation for the funder ........... 10

1.2. Historical assumptions of coporate social responsibility, further development

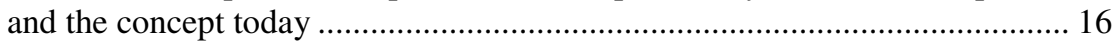

1.3. Evaluation of corporate social responsibility criteria ……............................... 22

1.3.1. Criteria according to Lithuanian and foreign institutions ....................... 23

1.3.2. Criteria according to international standards ............................................ 26

1.4. Corporate social responsibility criteria ............................................................ 29 
1.5. Theoretical background formation of corporate social responsibility evaluation system

1.5.1. The coherence of corporate social responsibility and financial results of

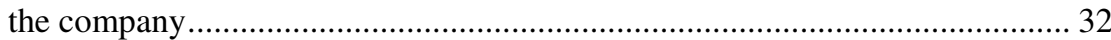

1.5.2. Triple bottom line theory ………………….......................................... 35

1.5.3. Integration of financial ratios into corporate social responsibility

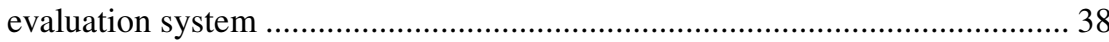

1.6. Conclusions of chapter 1 and formulation of objectives .................................... 40

2. THEORETICAL MODELING OF CORPORATE SOCIAL RESPONSIBILITY COMPLEX EVALUATION SYSTEM

2.1. Modeling the algorythm of complex evaluation system of corporate social responsibility

2.2. The maturity of the sustainability determination for the commercial banks that are operating in Lithuania

2.3. Formation of the criteria set for corporate social responsibility complex evaluation system

2.4. Theoretical modeling of complex evaluation system of corporate social resposnibility using multiple criteria decision making methods ........................5 54

2.4.1 Determination of criteria weights using AHP method............................... 54

2.4.2. Other multiple criteria decision making methods integration and their

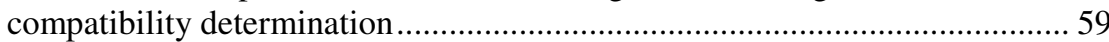

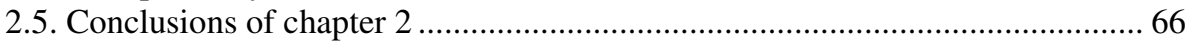

3. PRACTICAL MODELING AND APPLICATION OF CORPORATE SOCIAL RESPONSIBILITY COMPLEX EVALUATION SYSTEM.

3.1.Modeling the final complex evaluation system of corporate social responsibility

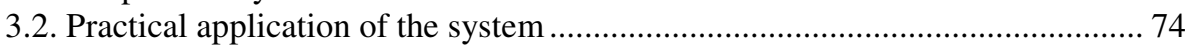

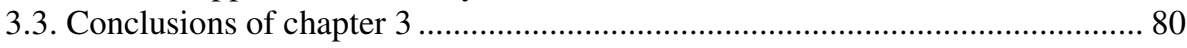

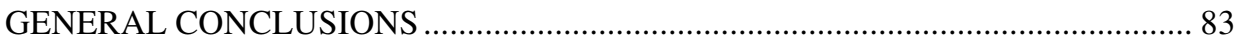

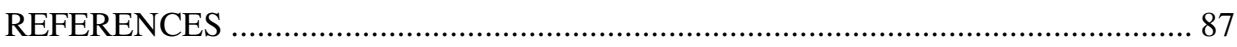

LIST OF SCIENTIFIC PUBLICATION BY THE AUTHOR ON THE TOPIC

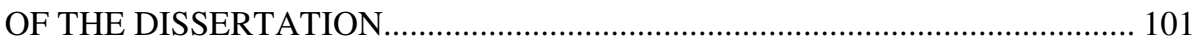

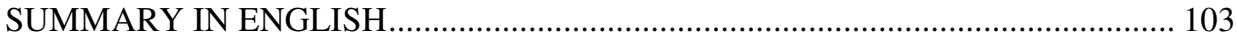

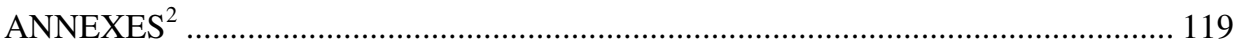

Annex A. A detailed financial ratios' group........................................................ 120

Annex B. The structure of sustainability maturity for the commercial banks ........ 123

Annex C. The maturity of the sustainability determination for the commercial banks that are operating in Lithuania........................................................... 125

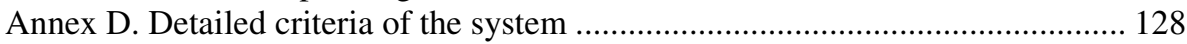

${ }^{2}$ The annexes are available in the $\mathrm{CD}$ attached to the dissertation. 
Annex E. Determination of criteria weights based on expert assessment method . 130

Annex F. An example of criteria weights calculation ........................................ 135

Annex G. Criteria weights final calculation according to AHP method................. 136

Annex H. Practical application of the system..................................................... 138

Annex I. Calculations using multi-criteria decision making methods for measuring

corporate social responsibility of three companies ....................................... 140

Annex Y. Ranking of expert evaluation .............................................................. 144

Annex J. Authors' Declaration of Academic Integrity............................................. 147

Annex K. The Co-Authors Agreements to Provide Published Material in the

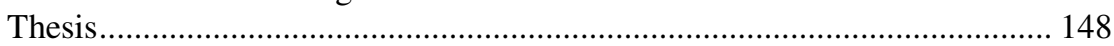

Annex L. Copies of Scientific Publications by the Author on the Topic of the

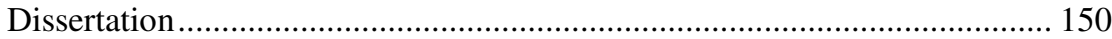





\section{Ivadas}

\section{Problemos formulavimas}

İvairūs ekonominiai pokyčiai valstybèse, demografiniai, socialiniai bei klimato pasikeitimai, valstybių reguliavimai bei įstatymai, tarptautinių standartų atsiradimas bei suinteresuotų šalių elgsena - visa tai intensyviai veikia ịmones ir jas supančią aplinką. Finansuotojai, arba dar tiksliau,- bankai, kaip vieni aktyviausių finansų sistemos ir visos ekonomikos dalyvių, įmones labiausiai gali paveikti per jų finansavimo procesą. Tačiau, kaip parodè prieš mažiau nei dešimtmetị pasauli sukrètusi finansų krizè, bankai per greitai siekè gauti pelną ir mažai dèmesio skyrè kredito rizikos valdymui ir atsakingam skolinimui. Naujų paskolų portfelis Lietuvoje augo itin dideliu greičiu - nuo 2,3 mlrd. EUR 2005 metais iki 4,9 mlrd. EUR 2006 metais, atitinkamai augindamas ir banku pelnus (didžiųjų šalies bankų - „Swedbank“ AB ir SEB banko grynasis pelnas išaugo daugiau nei dvigubai lyginant 2005 metus su 2007 metais). Tačiau paskolų augimas nebuvo tvarus ir 2008 metais minètieji bankai pradejjo skaičiuoti didelius atidèjinius savo paskolų portfeliams - specialieji atidèjiniai sudare 9-10 proc. nuo viso turimo paskolų portfelio (lyginant su 1 proc. 2005-2007 metais). Atitinkamai mažèjo ir bankų pelnai - didžiausią nuostoli abu bankai patyre 2010 metais, kuris sudare $0,3-0,4$ mlrd. EUR. Visi šie drastiški pokyčiai buvo tarsi signalas, jog finansų sektorius juda ne ta kryptimi. 
Šiandien bankai finansuodami įmones turi itin praplèsti savo požiūrįi. Siekdami užtikrinti visų pirma savo finansini stabilumą, išlaikyti aukštą saugumo ir patikimumo lygi bei prisidèti prie visos ekonomikos raidos, bankai turi koncentruotis ne tik i pelno siekimą, bet labiau vadovautis holistiniu požiūriu - efektyviau valdyti savo turimus resursus, nuolatos gerinti paskolų portfelio kokybę, geriau pažinti savo klientus - finansuojamas įmones, bei prisidèti prie tvarios ekonomikos ir socialinès raidos. Vienas iš būdų siekiant tvarios bankininkystės tikslų - finansuojamų įmonių socialinès atsakomybės vertinimas.

Nors šiandien socialinès atsakomybès aspektụ integravimo ị kasdienę veiklą nauda yra suprantama tiek dažnai i̇monei, tiek ją finansuojantiems bankams, problemų kyla tada, kai siekiama ịvertinti įmoniu socialinę atsakomybę praktiškai, t. y. iš finansuotojo pozicijos. Šiuo metu bankų taikomi finansuojamų įmonių socialinès atsakomybès vertinimo būdai yra gana riboti - jie apima tik tam tikrą i̇moniu socialinès atsakomybės sritị (pvz., aplinkosauginę) arba pavienius kriterijus. Be to, pats I̦SA vertinimas nèra nuoseklus ir sistemingas.

Tai, kad nèra tinkamo finansuojamų i̇monių socialinės atasakomybės vertinimo ịrankio, gali sąlygoti dvi tarpusavyje susijusios priežastys. Pirma, ISA vertinimas finansuotojo požiūriu yra vis dar nauja ir ribota mokslinių tyrimų sritis. Antra - tam, kad būtu galima sistemingai vertinti finansuojamų įmonių socialinę atsakomybę, pirmiausia reikia apibrèžti, ką ji apima. Kitaip tariant, svarbu nustatyti ịmonių socialinės atsakomybės vertinimo pagrindą sudarančius kriterijus, kurie būtų aktualūs būtent finansuotojams, bei rasti tinkamiausią būdą tuos kriterijus įvertinti. Todèl formuluojama mokslinio darbo problema - kaip reikètų vertinti įmonių socialinę atsakomybę finansuotojo požiūriu.

\section{Darbo aktualumas}

Pasaulinė finansų krize, kuri 2008 metais prasiveržè JAV finansų rinkų epicentre, daugiau ar mažiau paveikè praktiškai visas išsivysčiusias ir ekonomiškai stiprias valstybes. Kai kurios valstybès iki šiol jaučia krizès padarinius išaugusị nedarbą bei bendrą ekonominị nuosmukį. Finansų sektoriui pasaulị ištikusi krizè buvo tarsi signalas, indikuojantis, jog bankininkyste juda ne ta kryptimi, todèl finansų institucijos itin susirūpino, kaip atgauti žmonių ir verslo pasitikèjimą bei kaip būtų galima geriau prisidèti prie bendro tvaraus socialinio ir ekonominio augimo. Siekiant šių tikslų bei norint išvengti panašių krizių ateityje, buvo ieškoma ịvairių ịrankių situacijai suvaldyti, taip iš esmès pakeičiant bankų veiklos filosofiją (Lentner et al. 2015, Matei, Voica 2013). Vienas iš tokių - ypatingą dėmesi skirti socialinei atsakomybei, kadangi bankų finansinis stabilumas, gerejjantys finansiniai rodikliai, etiška ir skaidri veikla bei 
atsakingai teikiamos finansų paslaugos padeda užtikrinti nuspejjamą ir patikimą veiklą, kuri, savo ruožtu, gali atstovauti visuomenès interesus aukštesniame lygyje. Kitaip tariant, be finansinių paslaugų teikimo, bankų socialiniai bei aplinkosauginiai tikslai šiandien taip pat atlieka itin svarbų vaidmenị.

Bankų finansuojamos įmonès savo veiklą vykdo įvairiuose pramonès sektoriuose, todèl bankas turètų būti pajègus ịvertinti visas galimas su kliento veikla ir veiklos sektoriumi susijusias rizikas. Be to, siekiant užtikrinti tvarią banko veiklą, svarbu vertinti ne tik finansinius įmonių veiklos rezultatus bei su jais susijusias rizikas, bet ir socialinius, aplinkosauginius, valdymo bei etikos aspektus (Matei, Voica 2013). Ir nors pastaraji dešimtmetị bankai finansuojamų imonių socialinès atsakomybès vertinimą èmé itin proaktyviai integruoti $\mathfrak{i}$ finansavimo veiklą ir i kasdienius procesus, bendrai finansuojamų įmonių socialinès atsakomybès vertinimas bankuose vis dar nèra sistemingas ir kompleksiškas. Jis daugiau fragmentiškas, nes vertinami pavieniai kriterijai arba tam tikra kriterijų grupè. Dèl šios priežasties finansuojant ịmones yra sudètinga nustatyti realų jų socialinès atsakomybès lygị. Netinkamas arba nepakankamas i̇monių socialinès atsakomybès vertinimas atitinkamai gali sąlygoti ne tik didesnę i̇monès riziką finansuotojo požiūriu, bet ir pabloginti paties banko paskolų portfelio kokybę, veiklos rodiklius (pavyzdžiui, kapitalo pakankamumo rodiklį), padidinti teismų riziką ar net pabloginti paties banko reitingą (Hu, Scholtens 2014). Todèl šiame disertaciniame darbe siūloma İSA kompleksinio vertinimo sistema, skirta finansuotojui, siekiančiam kompleksiškai ir sistemingai vertinti finansuojamų ịmonių socialinę atsakomybę, galètų padèti išspręsti šią problemą.

\section{Tyrimų objektas}

Darbo tyrimų objektas - įmonių socialinè atsakomybė finansuotojo požiūriu.

\section{Darbo tikslas}

Pagrindinis šio darbo tikslas yra sukurti kiekybiniais metodais pagrịstą įmonių socialinès atsakomybès kompleksinio vertinimo sistemą, skirtą finansuotojui, bei patikrinti jos tinkamumą vertinant pasirinktas įmones.

\section{Darbo uždaviniai}

Siekiant darbo tikslo formuluojami tokie uždaviniai: 
1. Atskleisti įmonių socialinès atsakomybès vertinimo svarbą tvarios bankininkystès ir ekonomikos raidos kontekste.

2. Išnagrinèti i̇monių socialinès atsakomybès atsiradimo prielaidas ir priežastis, istorinę raidą bei nustatyti sąsajas su tvarios plètros ir darnaus vystymosi sąvokų sampratomis.

3. Išanalizuoti įmonių socialinès atsakomybès šiandieninę sampratą, apžvelgti tarptautinių ir Lietuvos institucijų pateikiamas İSA kriterijų sąrankas bei İSA vertinimo metodus.

4. Suformuoti ịmonių socialinès atsakomybès kompleksinio vertinimo sistemos, skirtos finansuotojui, teorini pagrindą.

5. Parengti İSA kompleksinio vertinimo sistemos algoritmą, paremtą teoriniu sistemos modeliavimu bei pritaikyti ji praktiškai formuojant ISA kompleksinio vertinimo sistemą.

6. Sudarius ISSA kompleksinio vertinimo sistemą, patikrinti jos tinkamumą vertinant pasirinktas įmones.

\section{Tyrimų metodika}

Pirmame skyriuje, taikant analitinio tyrimo metodologiją (mokslinès literatūros sisteminimo, palyginimo, apibendrinimo, analizès ir sintezès metodus), atkleistas įmonių socialinès atsakomybės klausimo aktualumas, ISA kriterijų taikymo specifika bei jų vertinimo aktualumas ir problematika.

Antrame skyriuje, prieš pradedant teoriškai formuoti ISA kompleksinio vertinimo sistemą, nustatytas Lietuvoje veikiančių komercinių bankų brandumo lygis socialinès atsakomybès srityje. Siekiant šio tikslo naudoti tokie metodai kaip ekspertinis vertinimas, rezultatu sisteminimas, analize, palyginimas ir apibendrinimas, grafinis duomenų vaizdavimas. ISA kompleksinio vertinimo sistemos teorinis pagrindas sudarytas remiantis mokslinès literatūros apibendrinimu ir sinteze bei praktiniu modeliavimu, pasitelkiant matematinius daugiakriterinio vertinimo metodus.

Trečiame skyriuje, siekiant empiriškai patikrinti sudarytą ISA kompleksinio vertinimo modeli, taikomi ekspertinio vertinimo, analitinès hierarchijos proceso bei kiti daugiakriteriniai vertinimo, duomenų analizès, sisteminimo ir apibendrinimo metodai. 


\section{Darbo mokslinis naujumas}

Rengiant disertaciją, gauti šie ekonomikos mokslui nauji rezultatai:

1. Nustatyta įmonių socialinès atsakomybès, tvarios plètros ir darnaus vystymosi sąvoku sąsajas, sudarytas naujas ekonominès sėkmès ciklas bei atskleista finansuotojų atliekamo ịmonių socialinès atsakomybès vertinimo svarba tvarios ekonomikos raidos kontekste.

2. Sudarant İSA kompleksinio vertinimo sistemą, pasiūlyta integruoti ekonominius - finansinius kriterijus, kaip itin aktualius finansuotojui vertinant ịmonių socialinę atsakomybę. Be to, sudaryta sistema pasižymi vertinimo kriterijų bei sistemai sudaryti naudojamų metodų kompleksiškumu.

3. Sukurta i̇monių socialinès atsakomybès vertinimo sistema suteikia galimybę kiekybiškai vertinti finansuojamų ịmonių socialinès atsakomybę finansuotojo požiūriu, geriau ịžvelgti galimas rizikas, efektyviau paskirstyti turimus išteklius, taip pat priimti labiau ekonomiškai pagrịstus ir tvarius sprendimus.

\section{Praktinė darbo rezultatų reikšmė}

ISA kompleksinio vertinimo sistemos sudarymo tikslas yra pateikti finansuotojams rekomendacijas, kaip būtų galima efektyviau vertinti finansuojamų i̇monių socialinę atsakomybę, bei pasiūlyti ịrankị- įmonių socialinès atsakomybès kompleksinio vertinimo sistemą. Šis įrankis suteiktų bankams galimybę geriau pažinti finansuojamas įmones ir ịžvelgti galimas rizikas, o tai, savo ruožtu, leistų efektyviau valdyti ir paskirstyti banko išteklius, priimti labiau ekonomiškai pagrịstus ir tvarius sprendimus, padedančius siekti tvarios bankininkystės tikslų ir tuo pačiu leidžiančius užtikrinti tvarią ekonomikos raidą.

Sudaryta įmonių socialinès atsakomybès kompleksinio vertinimo sistema pasižymi universalumu - ji gali būti taikoma nustatant konkrečios finansuojamos įmonès socialinès atsakomybès lygi ir (arba) lyginant kelių finansuojamų įmonių socialinès atsakomybės lygius tarpusavyje. Taip pat İSA kompleksinio vertinimo sistema suteiktų galimybę nustatyti finansuojamos i̇monès silpnąsias ir stipriąsias socialinès atsakomybès sritis (pvz., atliekiant SSGG analizę) bei ižvelgti galimas rizikas. 


\section{Ginamieji teiginiai}

1. İmonių socialinė atsakomybė finansuotojo požiūriu yra vienas svarbiausių klausimų, i kuri reikia atsiželgti vertinant finansuojamų įmonių riziką ir priimant sprendimus dèl tokių įmonių finansavimo. Todèl šis vertinimas turi būti atliekamas kompleksiškai, tikslingai atrenkant ir suderinant skirtingų grupių vertinimo kriterijus: ekonominius - finansinius, aplinkosauginius, socialinius ir valdymo.

2. İmonių socialinès atsakomybès vertinimui tikslingai ir nuosekliai pritaikius daugiakriterinius vertinimo metodus galima sukurti patikimą i̇monių socialinès atsakomybės kompleksinio vertinimo sistemą.

3. Sukurta įmonių socialinės atsakomybès kompleksinio vertinimo sistema leidžia finansuotojui nustatyti finansuojamų įmonių socialinès atsakomybès lygị, įžvelgti galimas rizikas, efektyviau paskirstyti turimus išteklius ir geriau valdyti kredito riziką, o proaktyvus ir nuoseklus i̇monių socialinès atsakomybès kompleksinio vertinimo sistemos taikymas sudaro palankias sąlygas ekonominès sėkmės ciklui veikti.

\section{Darbo rezultatụ aprobavimas}

Disertacijos tema publikuoti 7 moksliniai straipsniai: vienas straipsnis publikuotas mokslo žurnale, įtrauktame ì Web of Science duomenų bazę (Slapikaitė, Tamošiūnienè 2017), trys - ì Scopus duomenų bazę (Slapikaitè, Tamošiūnienè 2013, Slapikaitè, Tamošiūnienè, Mackevičiūtė 2015, Slapikaitė 2016), vienas - monografijoje (Slapikaite, Tamošiūnienè 2015b), vienas recenzuojamame tarptautinès konferencijos leidinyje (Slapikaitè, Tamošiūnienè 2014) bei vienas - mokslo žurnale, cituojamame kitose duomenų bazèse (Slapikaitè, Tamošiūnienė 2015a).

Disertacijoje atliktų tyrimų rezultatai buvo paskelbti trijose mokslinėse konferencijose Lietuvoje ir užsienyje:

- Tarptautinejje konferencijoje VGTU „Contemporary Issues in Business, management and Education" 2014 m. Vilniuje;

- Tarptautinejje konferencijoje „UNITECH“2014 Gabrovo“ 2014 m. Gabrove, Bulgarijoje;

- Tarptautineje konferencijoje University of Lodz „Beyond Business as Usual. CSR Trends“ 2013 m. Lodzėje, Lenkijoje. 


\section{Disertacijos struktūra}

Disertaciją sudaro ịvadas, trys skyriai, skyrių išvados bei bendrosios išvados, literatūros sąrašas ir 13 priedų. Disertacijos apimtis be priedų - 119 puslapių. Darbe yra 24 numeruotos formulès, 18 iliustracijų ir 20 lentelių. Rengiant disertaciją panaudoti 192 literatūros šaltiniai.

Pirmoje darbo dalyje analizuojama įmonių socialinès atsakomybès svarba bankų veiklos ir visos valstybès ekonomikos kontekste, taip pat analizuojama i̇monių socialinès atsakomybės sampratos raida, apžvelgiami naujausi tyrimai ìmonių socialinès atsakomybès vertinimo srityje bei identifikuojamos bendros mokslinių tyrimų tendencijos. Antroje darbo dalyje, ịvertinus įmonių socialinės atsakomybès sampratos bei įmonių socialinès atakomybès vertinimo specifiką ir atsižvelgiant ị finansuotojų poreikị ISA vertinti kompleksiškai ir sistemingai, siūloma ir teoriškai modeliuojama ISA kompleksinio vertinimo sistema, skirta finansuotojui. Toliau, siekiant patikrinti antroje darbo dalyje pasiūlytu daugiakriterinio vertinimo metodų tinkamumą sudarant ISA kompleksinio vertinimo sistemą, trečioje darbo dalyje atliekami empiriniai tyrimai praktiškai sumodeliuojant sistemą bei pritaikant ją vertinant tris realias įmones - vieno Lietuvoje veikiančio komercinio banko klientes. Pabaigoje pateikiamos visas disertacinio darbo dalis apibendrinančios išvados ir įžvalgos. 



\section{1}

\section{Imonių socialinès atsakomybès vertinimo teoriniai aspektai}

Valstybių ir pasaulio ekonomikos mastu finansu institucijos yra vienas svarbiausių komponentų ir variklių. Visais laikais bankai atliko itin svarbų vaidmeni pritraukiant neįdarbintą kapitalą bei paskirstant turimus resursus. Tačiau XXI a. ị finansų sektorių atnešè kitokị požiūrị - siekdami valstybės socialinio ir ekonominio augimo, bankai pradejjo integruoti socialinès atsakomybès aspektus savo kasdieneje veikloje ir finansavimo procesuose.

Siekiant kompleksiškai ir sistemingai integruoti socialinès atsakomybès aspektus i verslo finansavimo procesus, visų pirma reikia nustatyti, kas yra įmonių socialinè atsakomybé finansuotojo požiūriu ir kaip ją būtų galima vertinti praktiškai. Ir nors diskusijos apie įmonių socialinę atsakomybę pradètos vystyti daug anksčiau, nei pasauli ištiko minèta finansų krizè, tačiau vieningos ir visuotinai pripažintos sampratos ir vertinimo sistemos, kurią galètų taikyti finansuotojas, vis dar nèra suformuota. Todèl šiame skyriuje siekiama išanalizuoti i̇monių socialinès atsakomybès svarbą bankams, ištirti įmonių socialinès atsakomybės sampratos raidą nuo pat modernių šaknų iki šių dienų, apžvelgti ìvairių tarptautinių, vietinių organizacijų bei standartų taikomus socialinès atsakomybès kriterijus. Taip pat ištirti, kokie atlikti naujausi tyrimai imonių socialinès atsakomybès vertinimo srityje bei identifikuoti vyraujančias bendras tendencijas pagal atliekamų tyrimų kryptis. Galiausiai, suformuoti 
teorinị pagrindą İSA kompleksinei vertinimo sistemai, skirtai finansuotojams, sukurti, ypatingą dėmesị skiriant İSA ir finansinès veiklos ryšio analizei.

Šio skyriaus rezultatai buvo paskelbti trijuose straipsniuose: Slapikaitė, Tamošiūnienè 2013; Slapikaitè, Tamošiūnienè 2015, Slapikaite, Tamošiūnienè, Mackevičiūtė 2015, ir dviejose konferencijų leidiniuose: Slapikaitè, Tamošiūnienè 2012; Slapikaitè, Tamošiūnienè 2014.

\subsection{Imonių socialinès atsakomybès vertinimo svarba finansuotojui}

Prieš mažiau nei dešimtmetį pasauli nuvilnijusi finansų krizė kartu su skaudžiais padariniais atnešè ir naudingų pamokų visų pirma pačiam finansų sektoriui. Itin didelèmis apimtimis augantis paskolų portfelis parodè, jog komerciniai bankai siekė pernelyg greitai gauti pelną ir per mažai dèmesio kreipé ì prisiimamą rizikos koncentraciją (Šarkinas 2008). Naujos paskolos, suteiktos nefinansinėms korporacijomis ir namų ūkiams Lietuvoje, augo dideliu tempu - 2006 metais naujų paskolų buvo suteikta už 4,9 mlrd. EUR, kai tuo tarpu 2005 metais tokių paskolų buvo 2,3 mlrd. EUR (paskolų portfelio augimas - 113 proc.). Krizès išvakarèse paskolų portfelio augimas sulètejjo - 2007 metais naujų paskolų portfelis sudare 5,7 mlrd. EUR (augimas 16 proc.) ir dar nuo sekančių metų naujų paskolų portfelis ịgavo priešingą tendenciją - didžiausias naujų paskolų portfelio mažejimas užfiksuotas 2010 metais (1,6 mlrd. EUR arba 46,7 proc.) (1.1 pav.) (Lietuvos statistikos departamentas).

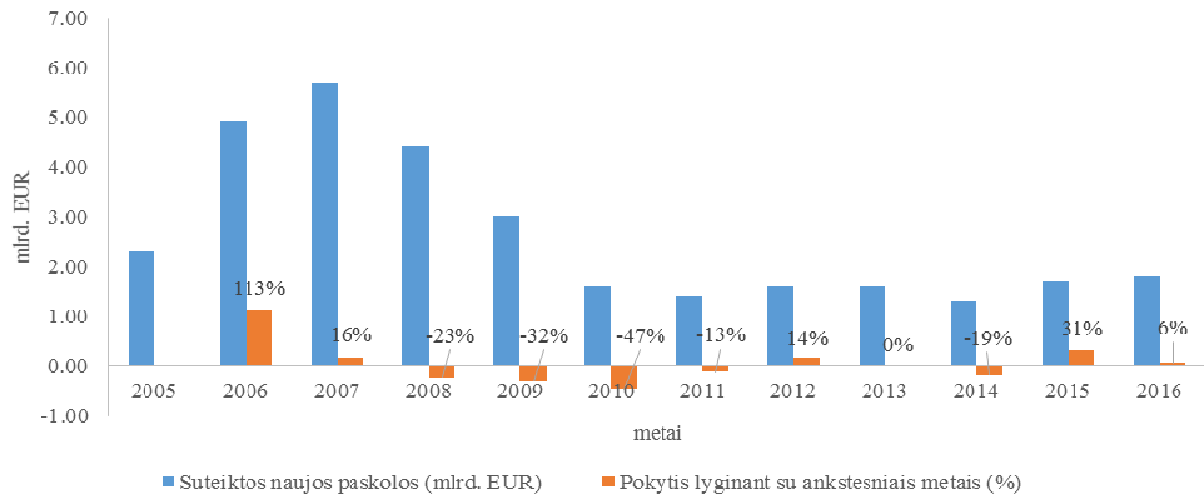

1.1 pav. Naujų paskolų nefinansinėms korporacijomis ir namų ūkiams suteikimo Lietuvoje tendencija 2005-2016 laikotarpiu (šaltinis: autorè, pagal Lietuvos statistikos departamento duomenis)

Fig. 1.1. New loan granted to non-financial corporations and households in Lithuania during 2005-2016 (source: author by Statistics Lithuania) 
Itin prastejjanti ekonominè situacija atskleidė dar vieną problemą - bankai per mažai dèmesio skyrè kredito rizikos valdymui ir atsakingam skolinimui (Šarkinas 2008). Ši faktą patvirtino ir dviejų didžiausių šalies bankų veiklos rodikliai. Augant paskolų portfeliams (2005-2008 metai), specialieji atidejiniai paskoloms sudarè apie 1 proc. nuo viso paskolų portfelio (1.2-1.3 pav.). Specialieji atidejjiniai arba kitaip - vertès sumažejjimas yra sudaromi paskoloms, kurioms nèra nustatytas individualus vertès sumažejjimas, tačiau yra tikimybè, jog šių paskolų vertė sumažès ir bankas atgaus atitinkamai mažesnę suteiktų paskolų sumą.

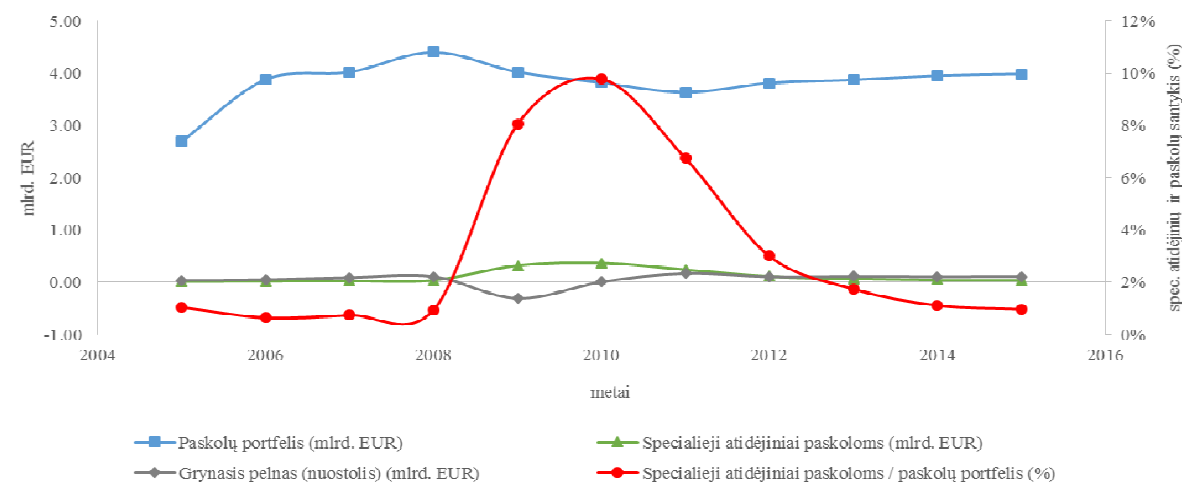

1.2 pav. „Swedbank“ AB veiklos Lietuvoje retrospektyva (šaltinis: autorè, pagal AB „Swedbank" veiklos ataskaitas)

Fig. 1.2. "Swedbank" AB retrospective of activity in Lithuania (source: author by "Swedbank" AB financial reports)

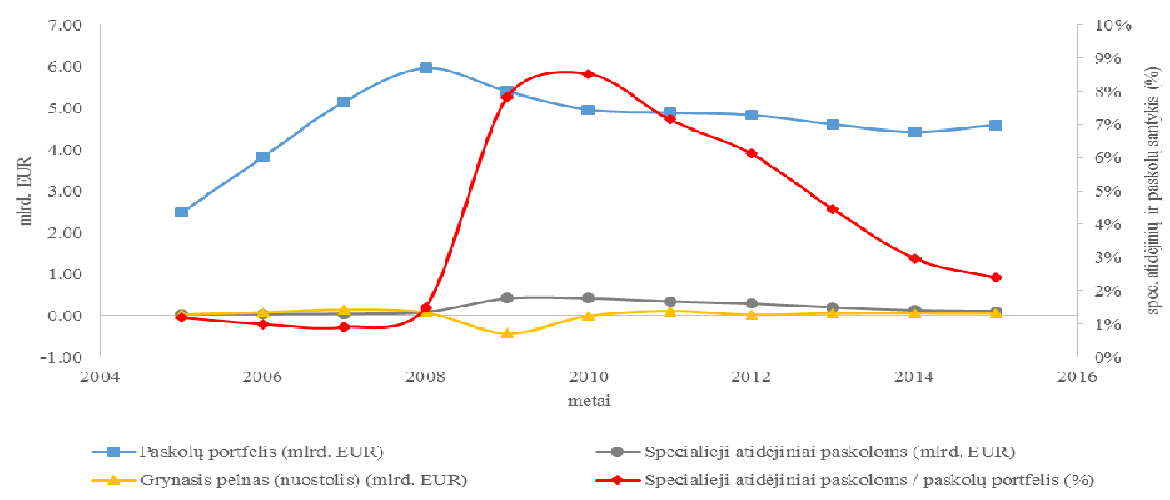

1.3 pav. AB SEB banko veiklos Lietuvoje retrospektyva (šaltinis: autoré, pagal AB SEB banko veiklos ataskaitas)

Fig. 1.3. AB SEB bank's retrospective of activity in Lithuania (source: author by AB SEB bank's financial reports) 
Situacija iš esmès pasikeitė 2009 metais, kuomet abiejų bankų paskolų portfeliai èmè mažèti, o specialieji atidejjiniai paskoloms didèti. 2010 metais specialieji atidèjiniai paskoloms sudare apie 9-10 proc. nuo viso paskolų portfelio. Šie skaičiai parodo, jog bankai turejjo realią galimybę prarasti tokią visų paskolų portfelio dali.

Negana to, bankai patyre didžiulius nuostolius - „Swedbank“ AB didžiausias nuostolis 2009 metais siekè 0,3 mlrd. EUR, AB SEB banko tais pačiais metais - 0,4 mlrd. EUR. Prastejjant bendrai ekonominei situacijai ir bankų veiklos rodikliams, buvo būtina imtis veiksmų, kurie padètų susigrąžinti bankų finansini stabilumą ir saugumą bei padètų atgauti visuomenès ir verslo pasitikèjimą.

Siekdami suvaldyti esamą situaciją bei išvengti panašių finansinių krizių ateityje, bankai iš esmés pakeité savo veiklos filosofiją ir strategiją- èmé vadovautis labiau holistiniu požiūriu. Imta koncentruotis ne tik ị pelno siekimą, bet ir i efektyvesni turimų resursų valdymą, griežtesnị skolininkų rizikos vertinimą ir valdymą, nuolatinị paskolų portfelio kokybès gerinimą ir pan. Vienas iš būdų siekiant tvarios bankininkystès tikslų - finansuojamų įmonių socialinès atsakomybès vertinimas.

Anot Lindgreen et al. (2009), socialinių ir aplinkosauginių aspektų integravimas ị kasdienę įmonès veiklą ir ịmonių sąveika su suinteresuotomis šalimis sąlygoja naują ekonominès sėkmès (angl. Economic success) modelį. Kadangi „bankų, kaip svarbių valstybės ir visuomenès atžvilgiu institucijų, veikla tiesiogiai turi įtakos kiekvienam“ (Čiegis, Norkutė 2012), siūloma ekonominès sèkmès modelio idèją praplèsti, įtraukiant bankus, kurie suinteresuoti i̇monių kasdiene veikla ir jos rezultatais, bei valstybę, kuri suinteresuota tiek sėkminga įmonių, tiek pačių bankų veikla. Kitaip tariant, praplèsta ekonominès sèkmès modelio idèja apima:

- įmones, kurių veikloje taikomi socialinès atsakomybès principai ir kurios atitinkamai turi įtakos bankų veiklos rezultatams;

- bankus, kurie siekdami tvarios bankininkystès tikslų, finansuodami atsižvelgia ir vertina įmonių socialinę atsakomybę. Tokie bankų tikslai atitinkamai prisideda prie valstybès ekonominio augimo;

- valstybę, kurios ekonominis augimas sukuria palankesnes verslo vystymo sąlygas (pvz., mokestinių lengvatų pavidalu, sukuriant palankesnes sąlygas naujo verslo kūrimui ir pan.).

Be abejo, ryšys tarp subjektų nėra tik vienpusis: tiek bankai veikia įmones, tiek valstybè veikia bankus. Dèl šio glaudaus veiksnių tarpusavio ryšio, siūloma reiškinị ịvardinti nauja sąvoka - ekonominès sèkmès ciklu (1.4 pav.).

Tokia sisteminiu mąstymu ir svarbiausiais gamtos dèsniais paremta ekonominès sėkmès ciklą sudaranti vystymosi filosofija gali būti apibrèžiama kaip darnus vystymasis. Norint užtikrinti šios sistemos patvarumą ir sistemą 
sudarančių veiksnių tęstinumą, visų pirma svarbu šios sistemos nepažeisti, taip pat saugoti socialinị teisingumą ir ekonominę gerovę. Kitaip tariant, reikia tik tokių sprendimų, kurie būtų priimami, atsižvelgiant ì finansinius, aplinkosauginius, socialinius ir etikos klausimus (Kleinaitè, 2007).

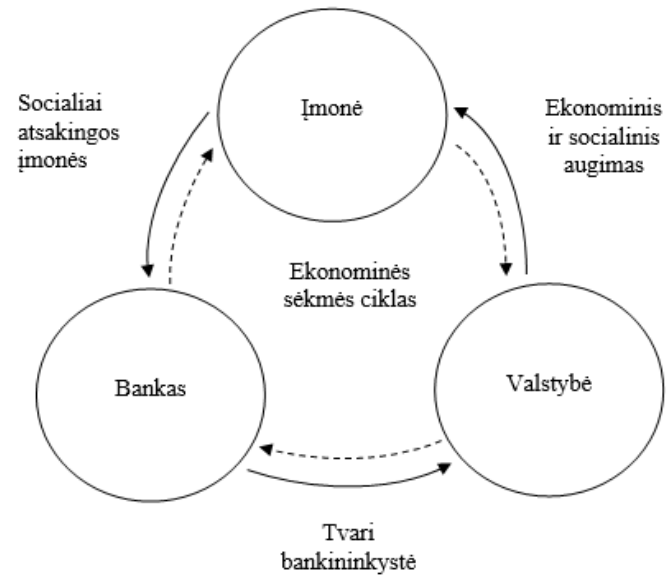

1.4 pav. İmonių socialinè atsakomybè ir ekonominès sèkmès ciklas (sudaryta: autorès)

Fig. 1.4. Corporate social responsibility and the cycle of economic success (source: author)

Vienas iš tokių sprendimų arba esminè darnaus vystymosi sąlyga - İSA strategijos taikymas įmonių ir bankų veikloje (Kovaliov, Snieška, Simanavičius 2009, Lietuvos Respublikos seimas 2012). Anot pasaulinès metodinès literatūros (REPORT 2014: Environmental, Social and Governance: Integration for Banks: a Guide to Starting Implementation), skirtos komerciniams bankams, siekiantiems tvarios bankininkystès tikslų, finansuojamų (ir ne tik finansuojamų) imonių socialinè atsakomybè ir jos vertinimas yra itin svarbus dèl kelių priežasčių:

1. Komerciniai bankai yra vienos pagrindinių institucijų, padedančių užtikrinti ilgalaikị finansini stabilumą tiek finansų rinkose, tiek visos ekonomikos mastu.

2. Komerciniai bankai padeda užtikrinti ekonomikos vystymąsi bei socialinị šalies augimą.

3. İvairūs tarptautiniai ir valstybių reguliavimai, suinteresuotų šalių spaudimas, demografiniai bei klimato pasikeitimai - visa tai veikia ne tik verslą ir jo aplinką, bet ir komercinius bankus. 
4. Netinkamas arba nepakankamas įmonių socialinès atsakomybès lygio ịvertinimas gali sąlygoti banko reputacijos ir vardo sumeninkinimą bei nenumatytas išlaidas.

5. Netinkamas arba nepakankamas įmonių socialinès atsakomybès lygio ìvertinimas gali turèti finansini poveiki arba net pabloginti banko reitingą, nusakantị banko patikimumo ir saugumo lygi:

- pablogèjusi banko paskolu portfelio kokybė (daugiau aukštos rizikos klientų), o tai atitinkamai blogina banko veiklos rodiklius, pavyzdžiui, ROA;

- didèja teisminių ginčų rizika (dèl banko klientų ịsipareigojimų nevykdymo);

- didèja banko kapitalo kaštai (blogėjanti banko paskolų portfelio kokybė sąlygoja aukštesnius kapitalo kaštus);

- blogejja BIS (angl. Bank for International Settlements) banko kapitalo pakankamumo rodiklis, kuris nusako banko rizikingumą, atsižvelgiant $\mathfrak{i}$ jo turto bei kapitalo struktūrą (Hu, Scholtens 2014).

2015 m. mokslininkai (Lentner et al.) imonių socialinę atsakomybę sudarančią keturių pagrindinių atsakomybès sričių piramidę (sudarytą Carroll 1991) pasiūlè pritaikyti bankininkystès sektoriui. Tradiciškai Carroll (1991) sudaryta piramidè apima šias sritis (1.5 pav.):

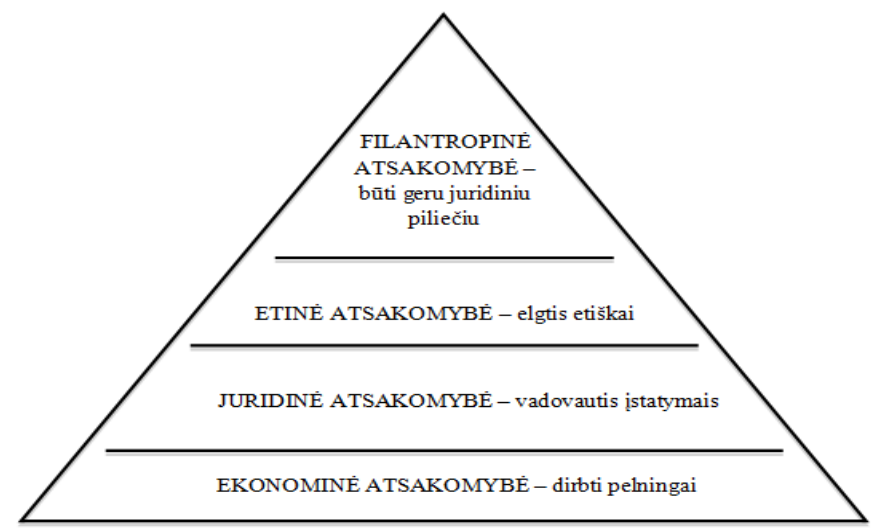

1.5 pav. Socialinès atsakomybès sritys (šaltinis: Carroll 1991)

Fig. 1.5. Social responsibilities (source: Carroll 1991)

Lentnerio et al. (2015) socialinès atsakomybès piramidès pritaikymas bankininkystės sektoriui taip pat apima tas pačias sritis:

- Ekonominè atsakomybė. Tai tradicinè ir pagrindiné priežastis, kodèl apskritai egzistuoja bankininkystė. Komercinių bankų pirminis tikslas yra grąža akcininkams, pelninga veikla ir augimas. Tuo tarpu viena iš 
varomųju jègų yra finansinès inovacijos. Bankai, siekdami prisitaikyti prie nuolat besikeičiančios verslo aplinkos, privalo ieškoti naujų galimybių efektyviai valdyti resursus bei riziką. Visa tai igyvendinama kuriant ir vystant naujus produktus bei perprojektuojant esamus produktus. Todèl sąveika su suinteresuotomis šalimis ekonominejje atsakomybeje yra itin svarbi.

- Teisinė atsakomybė. Reguliavimas visų pirma nustatomas pagal ịstatus, o pagrindinis tikslas yra sumažinti riziką, užtikrinti saugumą ir pasitikejjimą finansų sistemoje. Taip pat ịstatai yra papildomi ịvairiu suinteresuotų šalių išoriniu reguliavimu.

- Etinè atsakomybė dažniau iqgyvendinama individualiai pagal kiekvienos organizacijos sąmoningumo lygi ir tai, ko iš jos tikisi suintersuotos šalys. Etinè socialinès atsakomybès sritis finansų sektoriuje taip pat apima sąžiningumą, vientisumą, tinkamą elgesị, pagarbą ir skaidrumą.

- Filantropinè atsakomybė. Ši socialinès atsakomybès sritis neapima išorinių lūkesčių, tai yra visiškai savanoriška veikla. Tačiau pastaruoju metu tai tapo įprasta praktika bankininkystės sektoriuje.

Socialinès atsakomybés principų igyvendinimas bankininkystès sektoriuje yra labai platus - nuo su banko tiesiogine veikla susijusių veiksmų (atsakingas skolinimas, skaidrios finansinès paslaugos, banko produktų ir paslaugų pritaikymas specialius poreikius turintiems vartotojams, kova su pinigu plovimu, korupcija, terorizmu pan.) iki nesusijusių su tiesiogine banko veikla veiksmų (paramos akcijų inicijavimas ir rèmimas, parama ịvairioms bendruomenèms, sportui, menui, ịvairaus pobūdžio savanorystė ir pan.). Kuo daugiau socialinès atsakomybės principu igyvendinama banko veikloje, tuo aukštesnis paties banko socialinès atsakomybės lygis, kuris yra viena svarbiausių sąlygų tvariai bankininkystei vystyti (1.6 pav.).

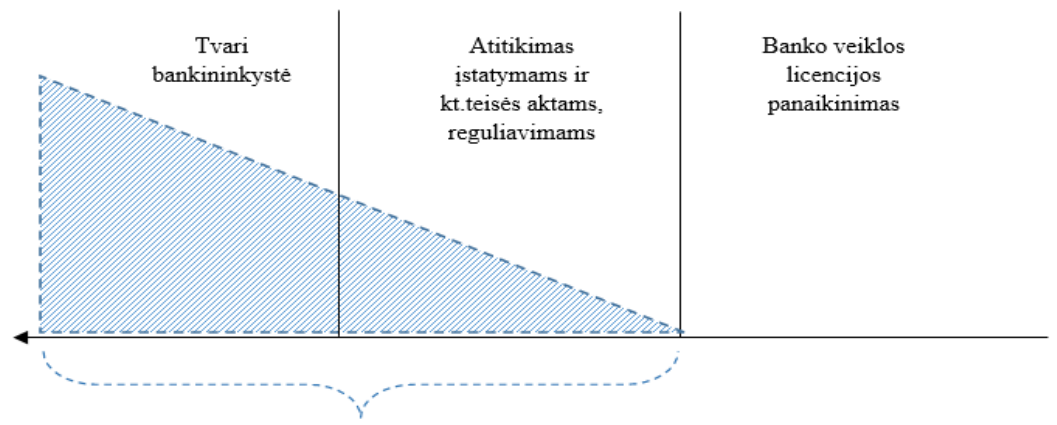

İSA principụ igyvendinimas

1.6 pav. Banko veiklos perspektyva igyvendinant socialinès atsakomybès principus savo veikloje (šaltinis: autorè)

Fig. 1.6. Bank's perspective in case of implementing CSR (source: author) 
Ir atvirkščiai, kuo mažiau socialinès atsakomybès principų igyvendinama banko veikloje, tuo labiau jis tolsta nuo tvarios bankininkystės tikslų (Shirley 2011). Visiškas socialinès atsakomybès principų nepaisymas sąlygoja ịvairias baudas bankui ar net licencijos banko veiklai vykdyti panaikinimą.

Taikant socialinės atsakomybės principus banko veikloje, sparčiau ir tvariau auga visu pirma pats bankas. Be to, kadangi valstybės ekonominis augimas yra neatsiejamas nuo bankų veiklos, galima teigti, jog tvari bankininkystė yra viena svarbiausių sąlygų valstybès ekonominiam augimui bei būtina sąlyga sẻkmingai veikti ekonominès sèkmès ciklui.

\subsection{Imonių socialinès atsakomybès atsiradimo prielaidos, istorinè raida bei šiandieninè samprata}

Daugelis mokslininkų ir tyrejų 1950 metus ịvardija kaip modernios İSA eros pradžią (Bowen 1953, Carroll 1999). Vèliau per artimiausius du tris dešimtmečius İSA sąvokos samprata buvo dar labiau išplèsta - prie ịmonių ekonominès ir teisinès atsakomybès prisidèjo atsakomybè visuomenei (socialinè atsakomybė) bei etiné atsakomybè (Carroll 1999; Elkington 1994) (1.7 pav.). $1971 \mathrm{~m}$. Johnsono pateikta I̦SA samprata, galima sakyti, visiškai atitiko šių dienų koncepciją - socialiai atsakinga įmoné yra ta, kurios vadovai sugeba subalansuoti visų šalių interesus. Užuot tik siekęs pelno akcininkų naudai, socialiai atsakingas verslas atsižvelgia bei rūpinasi ir savo darbuotojų, tiekejjų, vartotojų, bendruomenès bei aplinkos interesais (Johnson 1971). $1980 \mathrm{~m}$. prisidèjo dar keletas naujų ISA sampratų, pavyzdžiui, tai, jog ịmonių socialinė atsakomybė yra įmonių socialinès politikos dalis (Epstein 1987), bei ịvairių empirinių tyrimų, tačiau pagrindinis pokytis yra atsiradusios alternatyvios teorijos - ìmonių socialinès veiklos (angl. Corporate social performance arba CSP), suinteresuotujų šalių teorija (angl. Stakeholder theory) bei verslo etikos teorija (angl. Business ethics theory) (Carroll 1999). Šios teorijos apima:

- Imonių socialinès veiklos teorija apima tris požiūrius - dimensijas: a) ar imonès atsakomybė apima daugiau nei tik rūpinimąsi ekonominiais ir teisiniais klausimais? b) problemos - klausimai, dèl kurių egzistuoja socialinè atsakomybė (pvz., aplinkosauginiai, produkto saugumo, diksriminacija ir pan.); c) elgesio filosofija - įmonès elgesys yra reaktyvus ar proaktyvus? (Carroll 1979);

- Suinteresuotųju šalių teorija apima organizacijos valdymo ir verslo etikos sritis. Organizacijos valdymo pagrindas yra moralus ir vertybėmis grịstas elgesys suinteresuotujų šalių atžvilgiu. Tradiciškai manoma, jog tik akcininkai labiausiai suinteresuoti imonès veikla, tačiau suinteresuotụjų šalių teorija numato, jog kitos vienaip ar kitaip 
dalyvaujančios suinteresuotosios šalys (darbuotojai, klientai, tiekejjai, kreditoriai, ịvairios bendruomenès, vyriausybinès ir nevyriausybinès organizacijos, profesinès sajungos ir pan.) yra ne mažiau svarbios (Freeman 1984, Miles 2012). Suinteresuotujų šalių teorija numato, jog įmonė yra neatsiejama nuo ịvairių suinteresuotų asmenų bei jų grupių ir turi būti atitinkamai valdoma atsižvelgiant ị juos (Dagilienè 2014). Kadangi suinteresuotujų šalių teorija yra glaudžiai siejama su socialine apskaita (socialinėmis ataskaitomis), Dagilienè (2014), remdamasi savo atliktais moksliniais tyrimais, išskiria tris pagrindines socialinès apskaitos informacijos vartotojų grupes: a) investuotojus; b) visuomenę - nevyriausybines organizacijas, žiniasklaidą, žurnalistus; c) darbuotojus ir profesines sajungas.

İSA tendencija: reaktyvus elgesys virto proaktyvia pasauline tendencija, ideologija virto būtinybe (Lee, Carroll 2011, Lindgreen et al. 2008).
İSA orientuota tik $\mathrm{i}$ organizacijos ekonominius tikslus ir atitikimą teisiniams reikalavimams (Bowen 1953).

Prie ekonominiụ tikslụ bei atitikimo teisiniams reikal avimams prisideda atsakomybe prieš visuomenẹ (McGuire 1963).

ISA apima platesnes sritis - ekonominẹ, teisinẹ, etinẹ ir socialinẹ atsakomybes (Carroll 1979).

ISA koncepcijoje poveikị visuomenei pakeité suinteresuotos šaliụ svarba (Epstein 1987, Maignan et al. 1999).

1987 m. pirmą kartą oficialiai Bruntland ataskaitoje (angl. Brunatland report) panaudota damaus vystymosi savoka, kuri apima tris esminius požiürius: ekonomini, aplinkos ir socialini vystymąsi (Burton 1987).

Suinteresuotos šalys - tai asmenys ar grupès, kurios turi nuosavybẻs teisẹ, teisinius ar kitokius interesus, arba kitaip susijusios su jimonès veikla praeityje, dabartyje arba ateityje (Clarkson 1995).

ISA suvokiama kaip tinkama, pag eidautina, etiška verslo elgsena, pasireiškianti per socialiai orien tuotas normu, vertybiụ bei jisitikinimu sistemas (Suchman 1995).

Taikant ISA ir toliau vadovaujamasi 4 pagrindiniais principais (ekonominé, teisinè, etinè bei socialinè atsakomybés), tačiau labiau proaktyviai nei bet kada anksčiau (Cho, Hong 2008,

Golob, Bartlett 2007, Hunter et al. 2008). Be to, anot Kov aliovo

et al. (2009), imoniụ social inè atsakomybẻ tapo esminè damaus vystymosi salyga.

2017

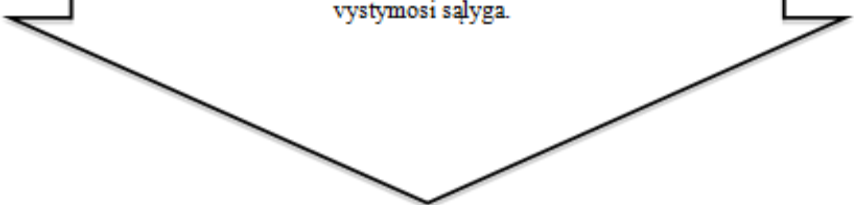

1.7 pav. Imonių socialinės atsakomybės sampratos raida (šaltinis: autorè)

Fig. 1.7. Genesis of corporate social responsibility concept (source: author) 
- Verslo etikos teorija yra grindžiama etinių problemų sprendimu ir verslo veiklos moralumu (Carroll 1999). Pruskus (2002) išskiria kelias pagrindines etines koncepcijas versle: religija ir verslas, utilitarizmo teorija, deontologiné etika, teisingumo etika, etinis reliatyvizmas bei krikščioniškos pažiūros.

Tačiau, nepaisant šių alternatyvių teorijų, anot Carroll (1999), imonių socialinès atsakomybės koncepcija išliko pagrindu kitoms teorijoms atsirasti.

Toliau analizuojant ịvairių mokslininkų ir tyrejų pateikiamas ISA sampratas, galima sudaryti İSA sampratos pokyčio genezę, kuri išryškina dvi pagrindines tendencijas:

1) Kai reaktyvus įmonių elgesys (kuris atsiranda kaip atsakas i išorès poveikị) socialinès atsakomybès klausimais virto proaktyvia (iniciatyvia) pasauline tendencija.

2) Kai ideologija virto būtinybe.

Nors įmonių socialinès atsakomybès esmè ir prasmès per pastaruosius kelis dešimtmečius itin keitèsi, poreikis siekti tvarios įmonès plètros ir darniai vystytis verslą supančios aplinkos atžvilgiu išliko. Todèl labai svarbu suvokti, kokia i̇monių socialinès atsakomybès prasmè yra šiandien.

İvairūs užsienio ir lietuvių mokslinininkai bei institucijos pateikia skirtingas ISA interpretacijas (1.1 lentelè). Tačiau nepaisant skirtingu İSA interpretacijų, anot Maignano et al. (2006), kiekviena organizacija turètų atrasti ir plètoti savo individualią İSA, nes kiekvienos organizacijos prioritetai ir suinteresuotujų šalių svarba gali skirtis. Apskritai, İSA reikšmė nèra ir negali būti visiems vienodai suprantama, nes strategija ir jos taikymo specifika gali skirtis dèl nevienodų veiklos sektorių, kuriuose ịmonès veikia, ịvairių ịmonių dydžiu ir netgi dèl geografinių regionų (Lindgreen et al. 2008b, Clarkson 1995, Maignan ir Ralston 2002). Be to, nors I ISA strategijos taikymo tikslai ir formos imonèse skiriasi, tačiau globali tendencija aiški - vis daugiau įmonių savo veikloje vadovaujasi ISA principais (Lee, Carroll 2011, Lindgreen, Swaen 2010).

1.1 lentelė. Imonių socialinės atsakomybės samprata XXI a. (šaltinis: autorè)

Table 1.1. Corporate social responsibility concept in the XXIst century (source: author)

\begin{tabular}{lll}
\hline \multicolumn{1}{c}{ Autorius } & Metai & \multicolumn{1}{c}{ Teiginys } \\
\hline $\begin{array}{l}\text { Rondinelli, } \\
\text { Berry }\end{array}$ & 2000 & $\begin{array}{l}\text { ISA - daugiamate strategija, apimanti ivairius kriterijus ir } \\
\text { aspektus. }\end{array}$ \\
\hline Banerjee & 2001 & $\begin{array}{l}\text { ISS strategija bus efektyviausia, jeigu bus integruota } \\
\text { visuose organizacijos lygmenyse kaip dalis bendros }\end{array}$ \\
\hline
\end{tabular}


1.1 lentelès tęsinys

\begin{tabular}{|c|c|c|}
\hline Autorius & Metai & Teiginys \\
\hline & & $\begin{array}{l}\text { organizacijos strategijos. Atskiri departamentai, kurie } \\
\text { rūpinasi vien tik tvarumo klausimais, gali būti per daug } \\
\text { nutolę nuo organizacijos strategijos, marketingo, finansų ar } \\
\text { personalo valdymo klausimų. }\end{array}$ \\
\hline $\begin{array}{l}\text { Europos } \\
\text { Komisija }\end{array}$ & 2002 & $\begin{array}{l}\text { İSA - tai veiklos koncepcija, integruojanti socialinius ir } \\
\text { aplinkosaugos veiksnius i įmonès veiklą ir } i \text { santykius su } \\
\text { suinteresuotomis šalimis. }\end{array}$ \\
\hline Pruskus & 2003 & $\begin{array}{l}\text { İSA apibūdinama kaip ,sąmoningai formuojamų } \\
\text { ekonominių, politinių, teisinių, dorovinių santykių tarp } \\
\text { organizacijos ir visuomenès, įvairių jos struktūrų forma, } \\
\text { pasirengimas atsakyti už savo poelgius ir veiksmus; } \\
\text { gebėjimas atlikti pareigą ir priimti visuomenès sankcijas, } \\
\text { esant tam tikroms teisingumo arba kaltumo sąlygoms“. }\end{array}$ \\
\hline $\begin{array}{l}\text { Lietuvos } \\
\text { socialinės } \\
\text { apsaugos ir } \\
\text { darbo } \\
\text { ministerija }\end{array}$ & 2005 & $\begin{array}{l}\text { İSA - tai įmonių ideologija, politika bei praktika, atspindinti } \\
\text { tokią ịmonių elgseną, kai jos i savo veiklą savanoriškai } \\
\text { įtraukia socialinius ir aplinkosaugos klausimus bei } \\
\text { santykiuose su visais suinteresuotais visuomenès, verslo ir } \\
\text { valdžios atstovais vadovaujasi pagarbos žmogui, visuomenei } \\
\text { bei gamtai vertybiniais principais. }\end{array}$ \\
\hline $\begin{array}{l}\text { Gruževskis et } \\
\text { al. }\end{array}$ & 2006 & $\begin{array}{l}\text { İSA yra apibūdinama kaip savanoriškos ịmonių pastangos } \\
\text { ịtraukti socialines ir aplinkos problemas i jų bendras veiklas } \\
\text { ir santykius su suinteresuotomis šalimis. }\end{array}$ \\
\hline Moon & 2007 & $\begin{array}{l}\text { Taikant İSA siekiama tarpusavyje subalansuoti skirtingas } \\
\text { ekonominę, teisinę, etinę ir socialinę atsakomybes, iš kurių } \\
\text { kiekviena kuria skirtingą pridėtinę vertę organizacijai. }\end{array}$ \\
\hline $\begin{array}{l}\text { Lindgreen } e t \\
\text { al. }\end{array}$ & $2008 \mathrm{a}$ & $\begin{array}{l}\text { İSA suprantamas kaip abipusiai naudingas (angl. win-win) } \\
\text { procesas organizacijai ir ją supančiai aplinkai. }\end{array}$ \\
\hline $\begin{array}{l}\text { Lindgreen } e t \\
\text { al. }\end{array}$ & 2008 & $\begin{array}{l}\text { İSA nėra viena konkreti veikla, tai rinkinys kelių skirtingų } \\
\text { veiklų, kurias organizacija gali pasirinkti savo veikloje. }\end{array}$ \\
\hline Gru & 2008 & $\begin{array}{l}\text { Imonių socialinè atsakomybė yra savanoriškas, ístatymų } \\
\text { nenulemtas organizacijų įsipareigojimas visose savo veiklos } \\
\text { srityse atsižvelgti ir derinti savo interesus su kitų šalių } \\
\text { interesais: vartotojų, darbuotojų, akcininkų, aplinkos, } \\
\text { bendruomenės bei kitų susijusių asmenų. }\end{array}$ \\
\hline $\begin{array}{l}\text { Bernatonytè } \\
\text { et al. }\end{array}$ & 2009 & $\begin{array}{l}\text { İSA gali būti apibūdintas kaip dinamiškas procesas, kurio } \\
\text { metu įmonè nuolat kinta, tobulèja, taip prisidèdama prie } \\
\text { darnaus vystymosi. }\end{array}$ \\
\hline
\end{tabular}


1.1 lentelès pabaiga

\begin{tabular}{lll}
\hline \multicolumn{1}{c}{ Autorius } & Metai & \multicolumn{1}{c}{ Teiginys } \\
\hline $\begin{array}{l}\text { Lindgreen } \text { et } \\
\text { al. }\end{array}$ & 2009 & $\begin{array}{l}\text { Manoma, jog ISA strategijos taikymas yra teisingai } \\
\text { pasirinktas kelias - lyderiaujančių organizacijų tinkamai } \\
\text { valdoma strategija yra būdas pagerinti veiklos rezultatus bei } \\
\text { atrasti daugiau galimybių versle. }\end{array}$ \\
\hline $\begin{array}{l}\text { Lindgreen, } \\
\text { Swaen }\end{array}$ & 2010 & $\begin{array}{l}\text { İSA ideologija tapo realybe - daugelis mano, jog ịmonè, } \\
\text { taikydama šią strategiją, taip nustato savo vaidmeni } \\
\text { visuomeneje. }\end{array}$ \\
\hline
\end{tabular}

Kiti autoriai, tokie kaip Moonas (2007), ịmonių socialinę atsakomybę glaudžiai sieja su darnumu arba tvarumu (angl. sustainability). İmonių socialinę atsakomybę jis aiškina kaip pastangas suderinti skirtingas ekonomines, teisines, etines ir socialines atsakomybes suinteresuotujų šalių atžvilgiu, kurios kiekvienai iš šalių sukuria nevienodą pridètintę vertę ir santykị su įmone. Autorius taip pat pabrèžia, jog nepaisant šios sampratos, įmonių socialinės atsakomybès apibrěžimas įmonèse gali skirtis dẻl nevienodų socialinių, aplinkosauginių ar etinių klausimų lygių ir reikšmingumo (svorių) įmonėje. O kalbėdamas apie darnaus vystymosi (angl. sustainable development) sąvoką, Moonas (2007) akcentuoja, jog priešingai nei İSA, darnus vystymasis neapima pastangu suderinti skirtingus aspektus - darnus vystymasis yra įmonès veikla, nukreipta i ją supančios aplinkos augimą Taip pat mokslininkas pabrezžia, jog tiek İSA, tiek darnaus vystymosi samprata neturi aiškių taisyklių ar principų šių sąvokų taikymas apibūdinant ịmonę yra gana laisvas.

Kiti mokslininkai İSA tiesiogiai kildina iš darnaus vystymosi ar tvarios plètros koncepcijų - užsienio literatūroje abi šios sąvokos bendrai vadinamos sustainable development. Lietuvos kalboje šių sąvokų prasmès skiriasi (Lietuvių kalbos žodynas 2015):

- žodžio „tvarus“ prasmès: a) tvirtas, patvarus; b) pastovus, nekintamas; c) turintis imunitetą, ištvermingas, atsparus; d) ilgai trunkantis, nepraeinantis;

- žodžio „darnus“ prasmès: a) kuris gražaus sudèjimo, tinkamas, gražus; b) susiderinęs, harmoningas.

Tačiau analizuojant tiek užsienio, tiek lietuvių literatūros šaltinius, pastebimi skirtumai tarp šių dviejų sąvokų. Pavyzdžiui, Fongwa (2010) ir Goelis (2010) labiau akcentuoja tokią įmonès veiklą, kuri užtikrina tęstinumą ir augimą būsimoms kartoms, tuo pačiu tenkinant dabartinius organizacijos poreikius. Bernatonytė et al. (2009) socialiai atsakingą verslą apibūdina kaip ịmonès indèlị ị darnų vystymąsi, t. y. ekonomikos augimą, socialinį vystymąsi ir aplinkosaugą. Kleinaitė (2007) ir Paužuolienė (2010) įmonių socialinę atsakomybę apibūdina 
kaip darnaus vystymosi principu praktini pritaikymą ịmonės veikloje, kadangi, anot Paužuolienės (2010), ISSA principų ịgyvendinimui įtakos turi ekonominiai, socialiniai ir aplinkosauginiai verslo veiksniai. Čiegis (2008) dar akcentuoja, jog itin svarbu šiuos tris elementus tarpusavyje suderinti ir vertinti vienodai. Anot Mathew (2009), Bagdonienès et al. (2011), Šimanskienès ir Paužuolienès (2011), darnus vystymasis yra suprantamas kaip tęstinis verslo ịsipareigojimas elgtis etiškai ir prisidèti prie ekonominio vystymosi gerinant verslą supančios aplinkos gyvenimo kokybę. Taigi, remiantis skirtingais autorių požiūriais - akcentais, galima sudaryti žemiau pateiktą İSA, darnaus vystymosi ir tvarios plètros sąvokų sąsają (1.8 pav.).

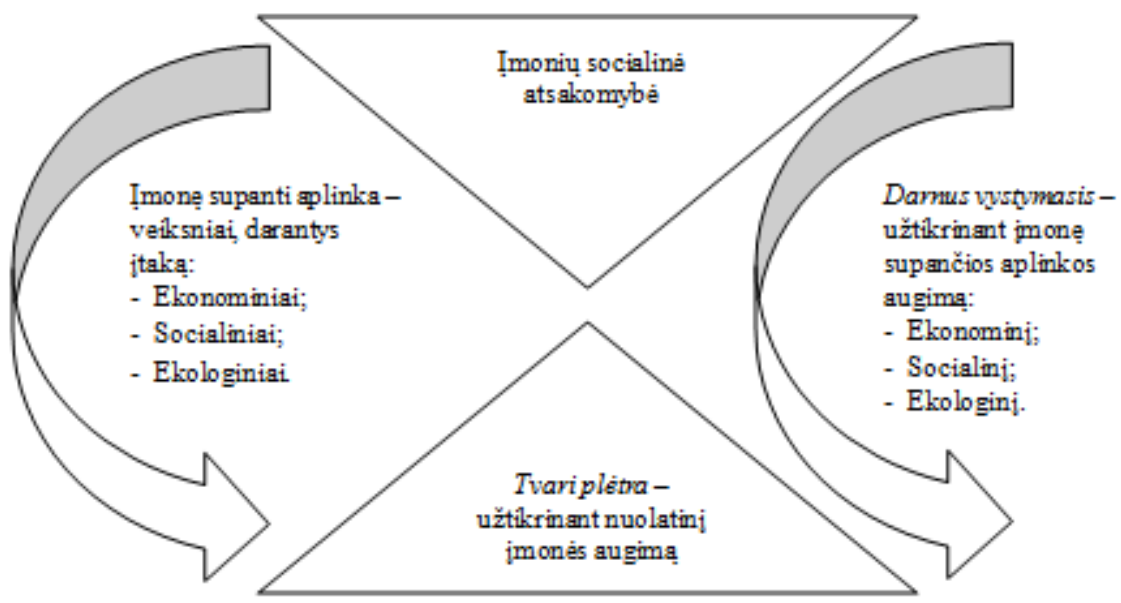

1.8 pav. İmonių socialinès atsakomybès, tvarios plètros ir darnaus vystymosi sampratos imones supančios aplinkos kontekste (šaltinis: autorè)

Fig. 1.8. Corporate social responsibility and sustainable development concepts in the context of business environment (source: author)

Nuo 2005 m. oficialiuose JTO dokumentuose ịvardijama, kad darnus vystymasis sujungia tris esminius požiūrius: ekonominị, aplinkos ir socialinį, kurie papildo vienas kitą. Bendrai darnus vystymasis užtikrina ne tik pačios organizacijos egzistavimą bei augimą, bet ir su ja susijusios aplinkos gyvavimo bei augimo tęstinumą.

Atskirai analizuojant šie požiūriai apima:

- ekonomikoje darnus vystymasis užtikrina, kad ateities kartų pajamos nebūtų mažesnès nei dabartinès kartos;

- sociologijoje darniu vystymusi siekiama išsaugoti bendruomenę ir glaudžius santykius su ja; 
- ekologijoje darnus vystymasis siekia išsaugoti biologinių rūšių ịvairovę, esmines ekosistemas ir ekologinius procesus.

Bendrai kalbant apie sąvoką „tvari plètra“, labiau akcentuojamas įmonès veiklos tęstinumas, būtinai atsižvelgiant ị poveikị aplinkai ir neatimant iš ateities kartu galimybės patenkinti savo poreikius (Storebrand 2015, Eko redakcija 2011). Vartojant „darnaus vystymosi“" sąvoką, priešingai, - jeigu kalbama apie konkrektų projektą ar įmonę, koncentruojamasi ne tik į juos, bet ir i kuo išsamesni poveikio aplinkai, visuomenei, ateities raidai tyrimą bei vertinimą (Eko redakcija 2011).

Unruhas (2008) papildė darnaus vystymosi sąvoką darnaus pertvarkymo sąvoka (angl. sustainable redevelopment), kuri apima esamų resursų išsaugojimą, atkuriant pažeistas ekosistemas. Tačiau dèl gana ribotų mokslinių tyrimų šioje srityje kol kas ị İSA darnaus vystymosi bei tvarios plètros sąvokų sąsają naujos sąvokos nesiūloma ịtraukti.

\subsection{Imoniụ socialinès atsakomybès kriterijai}

Kalbant apie socialinę i̇monių atsakomybę, vienas aktualiausių mokslinių ir praktinių klausimų visada buvo, kaip ją reikètų įvertinti. Dažniausiai İSA siejama su vienokiais ar kitokiais kriterijais, kurie veikia kaip rodikliai, kuriais galima ịvertinti socialinę ịmonių atsakomybę. Rodikliai arba kriterijai - tai tarsi supaprastintas bendravimo ir planavimo irankis, kuris padeda pasirinkti tarp alternatyvų ir priimti tinkamiausius sprendimus siekiant darnos. Svarbu, kad tam tikslui nustatomų rodiklių skaičius būtų ribotas ir jie būtų lengvai suprantami (Hardi et al. 1997, Čiegis et al. 2009, Spangenberg 2002). Taigi, reikia stengtis apimti ne visus ar kuo daugiau darnumo aspektų, nes dažnai jie tampa labai subjektyvūs ir beprasmiai, o suformuluoti aiškius bei apibréžtus darnumo tikslus ir atitinkamai parinkti kriterijus, kurie turètų būti nuolatos peržiūrimi ir tikslinami (Hueting, Reijinders 2004, Šimanskienè 2009b). Anot Moldano (2007), darnumo indikatoriai turi būti optimalūs, t. y. jie turi apimti esminius sistemos bruožus ir parodyti šios sistemos palaikymo ar mokslinio pagerinimo trajektoriją.

Taip pat svarbu nustatyti, kas yra įmonių socialinė atsakomybė konkrečiu atveju. Pavyzdžiui, Kinijoje socialiai atsakinga ịmonè yra ta, kuri gamina saugius bei kokybiškus produktus, Vokietijoje tokia įmone laikoma ta, kuri sukuria saugias darbo sąlygas savo darbuotojams, Pietų Afrikoje tokia įmonė visų pirma turi daryti poveiki socialiniams poreikiams - sveikatos priežiūros ir švietimo srityse. Netgi ịvairiose Europos šalyse įmonių socialinė atsakomybė gali būti suprantama gana skirtingai. Todèl, norint taikyti vienokius ar kitokius 
įmonių socialinès atsakomybès kriterijus, visų pirma reikia juos nustatyti kaip tinkamiausius tyrimui (Knox 2007, Saether et al. 2008).

\subsubsection{Pagal Lietuvos ir užsienio institucijas}

Vystantis ịmonių socialinei atsakomybei, kūrèsi įvairios tarptautinès ir vietinès organizacijos, reglamentuojančios imonių socialinę atsakomybę. $1999 \mathrm{~m}$. buvo ịkurtas Investuotojų forumas, šiandien jungiantis daugiau kaip 50 nariųstambiausių ir aktyviausių investuotojų Lietuvoje. Vienas iš organizacijos tikslų skleisti socialinès atsakomybės koncepciją Lietuvoje (Investuotojų forumas 2012). Vèliau, 2005 m., susiformavo Lietuvos atsakingo verslo asociacija (LAVA, prieš tai buvusi neformali organizacija Nacionalinio atsakingo verslo įmonių tinklo arba NAVĮT). Formalizavus organizaciją, 2013 m. ji tapo ir oficialia JT Pasaulio susitarimo atstovybe Lietuvoje. LAVA vienija ịvairiose srityse dirbančias įmones ir organizacijas, kurios siekia veikti atsakingai ir igyvendinti darnaus vystymosi principus (Lietuvos atsakingo verslo asociacija 2015). Šios dvi institucijos Lietuvoje oficialiai numato 1.2 lentelèje pateiktus I̦SA kriterijus.

1.2 lentelè. İmonių socialinès atsakomybès kriterijai pagal Lietuvos institucijas (šaltinis: Lietuvos atsakingo verslo asociacija 2016, Investuotojų forumas 2012)

Table 1.2. Criteria of corporate social responsibility according to the Lithuanian based institutions (source: Lietuvos atsakingo verslo asociacija 2016, Investuotojų forumas 2012)

\begin{tabular}{|c|c|c|}
\hline Organizacija & Šaltinis & İSA kriterijai \\
\hline \multirow[t]{7}{*}{ LAVA } & \multirow{7}{*}{$\begin{array}{l}\text { Asociacijos } \\
\text { istatai }\end{array}$} & Kiekvienas asociacijos narys įsipareigoja: \\
\hline & & $\begin{array}{l}\text { 1. Veikti vadovaudamasis sąžiningumo, skaidrumo, } \\
\text { teisingumo ir atsakingumo aplinkai principais, ypač } \\
\text { tais atvejais, kai situacijos nebūna aiškiai } \\
\text { reglamentuojamos. }\end{array}$ \\
\hline & & $\begin{array}{l}\text { 2. Gerbti ir laikytis visu isstatymų ir reikalavimų, } \\
\text { kurie reglamentuoja įmonès ar organizacijos veiklą. }\end{array}$ \\
\hline & & $\begin{array}{l}\text { 3. Vengti situacijų, kurios gali sukelti interesų } \\
\text { konfliktą ar sukompromituoti nari, pakenkti } \\
\text { asociacijos reputacijai. }\end{array}$ \\
\hline & & $\begin{array}{l}\text { 4. Laikytis JTO Pasaulinio susitarimo principų bei } \\
\text { siekti juos užtikrinti savo veiklos aplinkoje - tarp } \\
\text { partnerių, tiekejjų, kt.: }\end{array}$ \\
\hline & & $\begin{array}{l}\text { 4.1. Remti ir gerbti tarptautinę žmogaus teisių } \\
\text { apsaugą savo įtakos sferoje. }\end{array}$ \\
\hline & & 4.2. Netoleruoti žmogaus teisių pažeidimų. \\
\hline
\end{tabular}


1.2 lentelès pabaiga

\begin{tabular}{|c|c|c|}
\hline Organizacija & Šaltinis & İSA kriterijai \\
\hline & & $\begin{array}{l}\text { 4.3. Palaikyti darbuotojų asociacijų laisvę ir pripažinti jų } \\
\text { teisę ị derybas. }\end{array}$ \\
\hline & & $\begin{array}{l}\text { 4.4. Netoleruoti priverstinio ar vaikų darbo ir bet kokios } \\
\text { diskriminacijos, susijusios su įdarbinimu ir profesija. }\end{array}$ \\
\hline & & $\begin{array}{l}\text { 4.5. Remti prevencines programas, užtikrinančias } \\
\text { aplinkos apsaugą, ir imtis iniciatyvų aplinkosauginei } \\
\text { atsakomybei didinti. }\end{array}$ \\
\hline & & $\begin{array}{l}\text { 4.6. Skatinti aplinkai palankių technologijų vystymąsi ir } \\
\text { plitimą. }\end{array}$ \\
\hline & & $\begin{array}{l}\text { 4.7. Netoleruoti korupcijos, ịskaitant papirkinejjimą ir } \\
\text { kyšininkavimą, bei skatinti skaidrios veiklos principų } \\
\text { plètrą. }\end{array}$ \\
\hline & & $\begin{array}{l}\text { 4.8. Viešoje erdvèje (taip pat savo interneto svetainèje) } \\
\text { deklaruoti požiūrị i atsakingos veiklos principų } \\
\text { laikymąsi. }\end{array}$ \\
\hline & & $\begin{array}{l}\text { 4.9. Teikti ataskaitas apie vykdomą atsakingą veiklą } \\
\text { (savo interneto svetainèje, arba pateikiant nuorodas, kur } \\
\text { šios ataskaitos skelbiamos). }\end{array}$ \\
\hline \multirow[t]{2}{*}{$\begin{array}{l}\text { Investuotojų } \\
\text { forumas }\end{array}$} & \multirow[t]{2}{*}{$\begin{array}{l}\text { Etikos } \\
\text { kodeksas }\end{array}$} & $\begin{array}{l}\text { Kiekvienas asociacijos narys įsipareigoja vadovautis } \\
\text { verslo etikos principais: }\end{array}$ \\
\hline & & $\begin{array}{l}\text { 1. Teisingumas, skaidrumas ir atvirumas deklaruojant } \\
\text { verslo interesus. } \\
\text { 2. Atsakomybė už darbuotojus ir jų profesini tobulejiimą. } \\
\text { 3. Rūpinimasis, kad nebūtų diskriminacijos. } \\
\text { 4. Vadovavimasis galiojančiais ịstatymais ir teisès aktais, } \\
\text { ypač susijusiais su aplinkosauginiais klausimais } \\
\text { (stengiamasi sumažinti daromą poveikị aplinkai). } \\
\text { 5. İsitraukimas ị socialinius projektus / veiklą siekiant } \\
\text { šalies gerovès. }\end{array}$ \\
\hline
\end{tabular}

Nuo 2013 m. Socialinès apsaugos ir darbo ministerija kartu su Ūkio bei Aplinkos ministerijomis bei socialiniais partneriais organizuoja NAVA konkursą, kurio metu paskelbiamos kelios nominacijos - „Metu darboviete““, „Metų bendruomeniškiausia įmonè“, „Metų aplinkosaugos įmonë“ ir pan. Šios nominacijos tradiciškai skirstomos ị dar smulkesnes kategorijas - pagal ịmonès dydị, kapitalą (lietuvių ar užsienio) ir kitus kriterijus (Lietuvos Respublikos socialinès apsaugos ir darbo ministerija 2016). NAVA vertinimo sistemą sudaro 5 vertinimo kriterijai, kurie suformuluoti pagal 5 įmonių socialinès atsakomybès diegimo principus: a) ISA klausimų (sričių) identifikavimas įmonèje; b) suin- 
teresuotujų šaliu įtraukimas; c) İSA strateginių krypčių, veiksmų plano, veiklos atlikimo rodiklių apibrěžimas; d) İSA veiklos igyvendinimas ir rezultatų vertinimas; e) atskaitomybė apie ISSA veiklą (Jurkaitis et al. 2011). Remiantis šiais kriterijais, vertinama, kaip İSA integruojama verslo aplinkoje - pradedant nuo įmonès strategijos iki konkrečių veiksmų, iniciatyvų ir pan. Kitokių oficialių ISA kriterijų ar jų sudarymo sistemos nenumato nė viena ministerija Lietuvoje.

Iš užsienio organizacijų labiausiai žinomas JT Pasaulinis susitarimas (angl. UN Global Compact) - tai strateginè iniciatyva, apimanti įmones, kurios isipareigojusios savo strategijoje ir veikloje laikytis 10 visuotinai pripažintų principų žmogaus teisių, darbuotojų teisių, aplinkosaugos ir kovos su korupcija srityse (United Nations Global Compact 2014). Ši organizacija specialiame imonių socialinès atsakomybės vadove numato 6 İSA kriterijų grupes:

1. Žmogaus teisès (verslas vadovaujasi tarptautiniu mastu pripažintomis žmogaus teisèmis bei užtikrina, kad jos nebūtų pažeidžiamos).

2. Darbuotojai (verslas palaiko darbuotojų asociacijų ir sajungų kūrimąsi, užtikrina, kad nebūtų priverstinio ar privalomojo darbo, nebūtų naudojama vaikų darbo jèga bei nebūtų diskriminacijos dèl lyties, amžiaus ir pan.).

3. Aplinkosauga (verslas remia ir (ar) dalyvauja aplinkosauginèse programose, imasi iniciatyvos sprendžiant aplinkosauginius ir ekologinius klausimus, naudoja bei skatina naudoti aplinkai draugiškas technologijas).

4. Antikorupcija (kovoja su ịvairiomis korupcijos formomis) (United Nations Global Compact 2014).

Kita 1995 m. ikurta organizacija RobecoSAM koncentruojasi i socialiai atsakingą investavimą ir i i̇monių socialinę atsakomybę šiose srityse: turto valdymas, indeksavimas, privatus kapitalas ir jo valdymas, organizacijų tvarumo vertinimas (RobecoSAM 2015). Ši organizacija ịmonès tvarumo metodologijoje numato 5 İSA kriterijų grupes:

1. Bendrovès valdymas (apima valdybos sudèties ịvairovę, valdybos darbo efektyvumą, vadovybès darbo užmokesčio skaidrumą).

2. Mokesčiai (apima mokesčių strategiją, atskaitomybę bei rizikos valdymą).

3. Socialinè ir aplinkosauginè atskaitomybè (apima atskaitomybès rengimus apie įmonès socialines ir kitas iniciatyvas, pagrindinių veiklos rodikliu - tikslų nustatymą ir stebėseną).

4. Žmogiškasis kapitalas (apima darbuotojų ugdymą, mokymus, skatinimą tobulèti, privalomąsias programas pagal pareigybę, ịvairių kiekybinių rodiklių vertinimą bei grąžą iš investicijų i žmogiškajj kapitalą). 
5. Darbuotojų našumo rodikliai bei žmogaus teisès (apima darbuotojų našumo vertinimą bei prigimtinių žmogaus teisių paisymą) (RobecoSAM 2015).

Pasaulinè ataskaitų rengimo iniciatyva (angl. Global Reporting Initiative arba GRI) save pristato kaip pirmaujančią darnumo srityje. Ši organizacija skatina įmones rengti ataskaitas apie savo socialinę atsakomybę- pateikia socialinès atsakomybės ataskaitų rengimo gaires įmonėms, nepriklausomai nuo jų dydžio, veiklos sektoriaus ar veiklos vykdymo vietos (Global Reporting Initiative 2015). Socialinès atsakomybès ataskaitų rengimo gairèse numatomos 5 ISA kriterijų grupès:

1. Ekonominių klausimų valdymas (apima ịmonès veiklos rezultatų, vietos rinkoje, netiesioginio ekonominio poveikio valdymo klausimus).

2. Aplinkosauginių klausimų valdymas (apima medžiagų ir žaliavų, energijos, vandens, biologinès ịvairovès, emisijų i aplinką ir atliekų valymo, produktuc ir paslaugu teikimo bei transporto valdymo klausimus).

3. Socialinių klausimų valdymas (apima ịvairius darbo sąlygų bei žmogaus teisių valdymo klausimus).

4. Poveikio visuomenei klausimų valdymas (apima bendruomeniškumo, antikorupcijos, atskaitomybès visuomenei, atitikties įstatymams ir teisès aktams valdymo klausimus).

5. Produktų gamybos ir (ar) paslaugų teikimo valdymo klausimai (apima poveikio sveikatai ir saugumui, atitikties produktuc ir paslaugu ženklinimui, taikomos rinkodaros, kliento duomenu ir privatumo apsaugos bei atitikties ịstatymams ir teisès aktams valdymo klausimus) (Global Reporting Initiative 2015).

\subsubsection{Pagal tarptautinius standartus}

Autoriai Birkinas et al. (2009) mano, jog įmonių aplinkosauginius ir socialinius aspektus geriausiai numato triguba koncepcija: tarptautinis aplinkosaugos standartas ISO14001, JT Pasaulinis susitarimas (angl. UN Global Compact) bei Pasaulinė ataskaitų rengimo iniciatyva (angl. Global Reporting Initiative arba GRI). Kadangi ISO14001 apima tik aplinkosaugos vadybos sistemų sertifikavimą, ị standartų analizę ịtraukiamas ir daugiau İSA kriterijų apimantis SA8000 (Social Accountability 8000) bei ISO26000:

- SA8000 standartas priklauso tarptautinei SAI (angl. Social Accountability International) nevyriausybinei organizacijai, kuri numato socialinio atsakingumo standartus, teikia mokymus bei techninę pagalbą, padeda įmonėms užtikrinti socialiai atsakingą darbdavystès praktiką visoje ịmonès veiklos grandineje. Socialinio atsakingumo 
reikalavimus sudaro dvi dalys - bendrieji reikalavimai, pagrịsti tarptautinėmis normomis, bei reikalavimai vadybos sistemai, kurie skirti labiau atsižvelgiant ị ịmonès veiklos specifiką (Bureau Veritas 2015);

- ISO 14001 - pagrindinis vadybos sistemos standartas, apimantis reikalavimus aplinkosaugos vadybos sistemai (angl. Environmental management systems arba EMS) įdiegti. Standartas padeda sumažinti poveikị aplinkai, užtikrinti atitikimą teisiniams reikalavimams bei kontroliuoti kitus įmonių aplinkosauginius klausimus (NQA 2015);

- ISO 26000 - tarptautinis socialinès atsakomybès standartas (angl. Guidance on Social Responsibility), kuris nustato gaires bei rekomendacijas apie įmonių socialinę atsakomybę užtikrinančius principus, socialinès atsakomyès pripažinimą, suinteresuotų šalių ịtraukimą bei kitas socialinès atsakomybès sritis (Kvalitetas 2014, ISO 2015, Scalet, Kelly 2010). Standarte pateikiami socialinès atsakomybès terminai, aibrěžimai ir socialinès atsakomybès principai bei rekomendacijos, kaip imonių socialinę atsakomybę integruoti ì organizaciją (ISO 2015) (1.3 lentelè).

1. Ientelè. İmonių socialinę atsakomybę reglamentuojantys tarptautiniai standartai (šaltinis: sudaryta autorès, remiantis Bureau Veritas 2015, NQA 2015, Kvalitetas 2014, ISO 2015, Atsakingas verslas 2013)

Table 1. . Corporate social responsibility by the international standards (source: author by Bureau Veritas 2015, NQA 2015, Kvalitetas 2014, ISO 2015, Atsakingas verslas 2013)

\begin{tabular}{|c|c|c|c|}
\hline $\begin{array}{l}\text { Standarti- } \\
\text { zuota } \\
\text { vadybos } \\
\text { sistema }\end{array}$ & Šaltinis & Kriterijai & $\begin{array}{l}\text { Sertifikuota } \\
\text { imonių } \\
\text { Lietuvoje } \\
\text { (2013 m.) }\end{array}$ \\
\hline SA8000 & $\begin{array}{l}\text { Bendrieji } \\
\text { reikalavimai }\end{array}$ & $\begin{array}{l}\text { SA8000 bendrieji reikalavimai yra } \\
\text { susiję su: } \\
\text { - vaikų darbu; } \\
\text { - priverstiniu ir privalomuoju darbu; } \\
\text { - profesine sveikata ir sauga; } \\
\text { - darbuotojų organizacijų laisve ir } \\
\text { teise i kolektyvines derybas; } \\
\text { - diskriminavimu; } \\
\text { - drausmine praktika; } \\
\text { - darbo valandomis; } \\
\text { - atlyginimu už darbą. }\end{array}$ & 18 \\
\hline $\begin{array}{l}\text { ISO } \\
14001\end{array}$ & $\begin{array}{l}\text { Reikalavimai ir } \\
\text { naudojimo }\end{array}$ & $\begin{array}{l}\text { - gerinti aplinkos } \\
\text { veiksmingumą; }\end{array}$ & 667 \\
\hline
\end{tabular}


1.3 lentelès pabaiga

\begin{tabular}{|c|c|c|c|}
\hline $\begin{array}{l}\text { Standarti- } \\
\text { zuota } \\
\text { vadybos } \\
\text { sistema }\end{array}$ & Šaltinis & Kriterijai & $\begin{array}{c}\text { Sertifikuota } \\
\text { imonių } \\
\text { Lietuvoje } \\
\text { (2013 m.) }\end{array}$ \\
\hline & gairès & $\begin{aligned} & \text { - } \text { taupyti gamtinius ir energetinius } \\
& \text { išteklius; } \\
& \text { - mažinti valdymo kaštus; } \\
& \text { - užtikrinti teisinių reikalavimų } \\
& \text { vykdymą; } \\
& \text { - patenkinti klientų reikalavimus } \\
& \text { plečiant rinką; } \\
& \text { - palaikyti gerus santykius su } \\
& \text { visuomene; } \\
& \text { - sukurti saugias darbo sąlygas } \\
& \text { darbuotojams; } \\
& \text { - gauti investicijų verslo plètrai; } \\
& \text { - gerinti organizacijos įvaizdį; } \\
& \text { - } \text { sertifikuoti aplinkos apsaugos } \\
& \text { vadybos sistemą. }\end{aligned}$ & \\
\hline ISO 26000 & $\begin{array}{l}\text { Gairès bei re- } \\
\text { komendacijos }\end{array}$ & $\begin{array}{l}\text { Septyni socialinės atsakomybės } \\
\text { principai: } \\
\text { - atskaitomybė visuomenei, } \\
\text { ekonomikai ir aplinkai; } \\
\text { - skaidrumas; } \\
\text { - įsiklausymas ir reagavimas į } \\
\text { suinteresuotujų šalių interesus; } \\
\text { - ịstatymų viršenybės gerbimas; } \\
\text { - etiškas elgesys; } \\
\text { - laikymasis tarptautinio elgesio } \\
\text { normų; } \\
\text { - žmogaus teisių gerbimas. }\end{array}$ & $\begin{array}{l}\text { Nesertifikuoja } \\
\text { ma }\end{array}$ \\
\hline
\end{tabular}

Taip pat egzistuoja Aplinkosauginès veiklos indeksas arba AVI (angl. Environmental Performance Index), kuriuo vertinama įmonių aplinkosauginė veikla. AVI vertina įmonių poveiki ịvairioms ekosistemoms, žemei, orui ir vandeniui. Su AVI indekso pagalba galima aiškiai nustatyti, koks organizacijų poveikis aplinkai, bei suformuoti pagrindą organizacijos tobulintinoms sritims ir ateities tikslams bendrai (Savvidis, Ginoglou 2011). Organizacijos, kurios integruoja AVI savo veikloje: JT aplinkos apsaugos agentūra (angl. United Nations Environmental Protection Agency arba UN EPA), Europos aplinkos agentūra (angl. European Environment Agency arba EEA), Alinkosauginius leidimus reguliuojanti agentūra (angl. Environmental Permitting Regulations 
arba EPR), Ekovadybos ir audito sistema arba EVAS (angl. Eco Management and Audit Scheme).

Nepaisant šio naujo standarto - indekso, Savvidis ir Ginoglou (2011) taip pat priduria, jog nèra vieno globalaus pasaulinio standarto - tiesog yra organizacijos, ịmonès ir agentūros, kurios vertina ịmones pagal EVI indekso sistemą. O pagrindiniai pasauliniai standartai, kurie šiuo metu aktualūs, ISO26000, GRI, ACCA ir kt.

JT vystymo programos Lietuvoje leistame periodiniame leidinyje apie imonių socialinę atsakomybę, jos principus, teoriją bei praktiką, $2013 \mathrm{~m}$. taip pat buvo pateiktos socialinès atsakomybès kriterijų sąsajos su standartizuotomis vadybos sistemomis. Be jau minètų SA 8000, ISO 14001 ir ISO 26000 tarptautinių standartų, ISA kriterijai bei jų taikymas siejamas ir su kitomis, siauresnemis ar apimančiomis mažiau IISA kriterijų vadybos sistemomis ISO9001, EVAS. 2013 m. Lietuvoje buvo sertifikuota 1120, 3 ir 412 i̇monių atitinkamai pagal kiekvieną vadybos sistemą (Atsakingas verslas 2013).

\section{4. İmonių socialinès atsakomybès vertinimas}

Siekdami ịvertinti ịmonių socialinę atsakomybę, ịvairūs autoriai siūlo skirtingus vertinimo būdus: vieni vertina pagal patiriamą naudą tam tikruose organizacijos lygmenyse (Chang, Kuo 2008, Gazzola 2012, Mathew 2009, Bagdonienè et al., 2011, McWilliams, Siegel 2000, Šimanskienè, Paužuolienė 2010), kiti pagal naudą, kurią patiria suinteresuotos šalys (Fongwa 2010, Jurkaitis et al. 2011), treti - pagal vertès kūrimo grandinę (Jonikas 2014, Juščius, Jonikas 2013), rečiau İSA vertinama abstrakčiu - globaliu požiūriu (Kagan et al. 2003, Dhiman 2008, Corina et al. 2009). Toliau darbe bus detaliau pristatomi dažniausiai taikomi požiūriai, ypatingą dėmesị skiriant İSA vertinimui pagal suinteresuotas šalis.

Vieni mokslininkai İSA vertina ịvairiapusiškai - analizuoja ịvairią patiriamą naudą (Šimanskienè, Paužuolienė 2010), kiti labiau koncentruojasi ị tam tikrą organizacijos sritị, kurią veikia ịmonių socialinė atsakomybė (1.4 lentelè).

1. lentelė. Imonių socialinės atsakomybės taikymo nauda pagal sritis (šaltinis: autorè) Table 1.]. Benefits of corporate social responsibility according to the areas of business (source: author)

\begin{tabular}{clcl}
\hline $\begin{array}{c}\text { Tyrimu } \\
\text { kryptis }\end{array}$ & \multicolumn{1}{c}{ Autorius } & Metai & \multicolumn{2}{c}{ Teiginys } \\
\hline \multirow{2}{*}{$\begin{array}{c}\text { Finansiniai } \\
\text { rezultatai }\end{array}$} & $\begin{array}{l}\text { Stanwick, } \\
\text { Stanwick }\end{array}$ & 1998 & $\begin{array}{l}\text { ISA taikymas } \\
\text { finansinius rezultatus. }\end{array}$ \\
\cline { 2 - 4 } & Smith & 1990 & ISSA nauda pasireiškia tuo, kad vartotojai \\
\hline
\end{tabular}


1.4 lentelès tęsinys

\begin{tabular}{|c|c|c|c|}
\hline $\begin{array}{l}\text { Tyrimų } \\
\text { kryptis }\end{array}$ & Autorius & Metai & Teiginys \\
\hline & & & $\begin{array}{l}\text { yra pasirengę mokèti už paslaugas ar } \\
\text { prekes daugiau nei ịprastai. }\end{array}$ \\
\hline & Chang, Kuo & 2008 & $\begin{array}{l}\text { İSA strategijos taikymas daro teigiamą } \\
\text { įtaką ịmonès pelningumui ne tik tam tikru } \\
\text { laiko momentu, bet ir ilgą laikotarpi. }\end{array}$ \\
\hline & Gazzola & 2012 & $\begin{array}{l}\text { İSA strategijos taikymas teigiamai veikia } \\
\text { pelną bei santykius su finansu insti- } \\
\text { tucijomis. }\end{array}$ \\
\hline & Mathew & 2009 & $\begin{array}{l}\text { ISSA strategijos taikymas prisideda prie } \\
\text { įmonès našumo ir rezultatyvumo - taip } \\
\text { sukuriamas konkurecinis pranašumas } \\
\text { ilgalaikèje perspektyvoje. }\end{array}$ \\
\hline & $\begin{array}{l}\text { Bagdonienè } \\
\text { et al. }\end{array}$ & 2011 & $\begin{array}{l}\text { ISA nauda: padidèjusi ịmonès vertè } \\
\text { akcininkų atžvilgiu, sumažèjusios } \\
\text { sąnaudos, padidèjusios pajamos. }\end{array}$ \\
\hline & $\begin{array}{l}\text { Bagdonienè } \\
\text { et al. }\end{array}$ & 2011 & $\begin{array}{l}\text { Ženkliai pagerèjusi produktų / paslaugų } \\
\text { kokybe். }\end{array}$ \\
\hline $\begin{array}{l}\text { Produktų / } \\
\text { paslaugų } \\
\text { kokybė }\end{array}$ & Gazzola & 2012 & $\begin{array}{l}\text { Padidèjęs saugumo lygis, padedantis } \\
\text { išvengti nenumatytų krizių organizacijoje } \\
\text { ir taip užtikrinti produktų / paslaugų } \\
\text { kokybę. }\end{array}$ \\
\hline \multirow{3}{*}{$\begin{array}{l}\text { Socialinè } \\
\text { nauda }\end{array}$} & $\begin{array}{l}\text { Deal, } \\
\text { Kennedy }\end{array}$ & 1982 & $\begin{array}{l}\text { ISA nauda apima organizacijos vertybes } \\
\text { bei isitikinimus, verslo etiką, bendras } \\
\text { elgesio taisykles, skatina kontrolę ir } \\
\text { pasirengimą nenumatytoms situacijoms. }\end{array}$ \\
\hline & $\begin{array}{l}\text { Bagdonienè } \\
\text { et al. }\end{array}$ & 2011 & $\begin{array}{l}\text { ISA nauda: skatinamos inovacijos vi- } \\
\text { suomeneje, socialinis bendradarbiavimas } \\
\text { bei ịvairios socialinès programos. }\end{array}$ \\
\hline & Gazzola & 2012 & $\begin{array}{l}\text { ISA nauda apima padidèjusią darbuotojų } \\
\text { motyvaciją ir îsitraukimą i i ivairius proce- } \\
\text { sus, geresnį žmogiškujjų išteklių valdymą. }\end{array}$ \\
\hline \multirow{4}{*}{ Rinkodara } & $\begin{array}{l}\text { Sen, } \\
\text { Bhattacharya }\end{array}$ & 2001 & $\begin{array}{l}\text { Vartotojai yra linkę mokèti daugiau už tos } \\
\text { imonès produktus ar paslaugas, kuri } \\
\text { vadovaujasi İSA strategija. }\end{array}$ \\
\hline & $\begin{array}{l}\text { Juščius, } \\
\text { Snieška }\end{array}$ & 2008 & $\begin{array}{l}\text { Taikant İSA strategiją didèja ịmonès } \\
\text { konkurencingumas. }\end{array}$ \\
\hline & $\begin{array}{l}\text { Bagdonienè } \\
\text { et al. }\end{array}$ & 2011 & $\begin{array}{l}\text { İSA nauda: pagerejusi įmonès reputacija, } \\
\text { efektyvesnis naujų klientų pritraukimas, } \\
\text { padidęjęs klientų lojalumas. }\end{array}$ \\
\hline & Gazzola & 2012 & İSA nauda: organizacija tampa labiau ma- \\
\hline
\end{tabular}


1.4 lentelès pabaiga

\begin{tabular}{|c|c|c|c|}
\hline $\begin{array}{l}\text { Tyrimų } \\
\text { kryptis }\end{array}$ & Autorius & Metai & Teiginys \\
\hline & & & $\begin{array}{l}\text { toma visuomenès, gereja jos reputacija, } \\
\text { geriau vystosi gebèjimai numatyti naujas } \\
\text { veiklos tendencijas ir kryptis. }\end{array}$ \\
\hline & Hollos et al. & 2012 & $\begin{array}{l}\text { İmonès, kurių İSA sritis yra labiau } \\
\text { išvystyta, yra konkurencingesnès lyginant } \\
\text { su kitomis įmonėmis. }\end{array}$ \\
\hline
\end{tabular}

Taip pat neretai tyrejai İSA vertina pagal ISSA naudos gavèjus suinteresuotąsias šalis. Pagal Fongwa (2010), įmonès vertė suprantama kaip „pyragas“, kuriuo suinteresuotos keturios pagrindinès šalys - akcininkai, vadovai, darbuotojai bei valstybė. Jurkaitis et al. (2011) İSA naudą vertina net pagal 7 suinteresuotąsias šalis ( 1.5 lentelè).

1. Ientelė. İmonių socialinès atsakomybės nauda suinteresuotų šalių atžvilgiu (šaltinis: Jurkaitis et al. 2011)

Table 1. . Benefits of corporate social responsibility according to the interested parties (source: Jurkaitis et al. 2011)

\begin{tabular}{|c|c|}
\hline $\begin{array}{l}\text { Suintere- } \\
\text { suotoji šalis }\end{array}$ & Nauda \\
\hline Direktoriai & Didesnė nepriklausomybė, savarankiškumas. \\
\hline Akcininkai & $\begin{array}{l}\text { Didesnės investicijos iš etika pagrịstų pensijų fondų, daugiau } \\
\text { skaidrumo. }\end{array}$ \\
\hline Darbuotojai & $\begin{array}{l}\text { Didesnė motyvacija, darbo našumas; mažiau ginčų, streikų; } \\
\text { pritraukiami geresni specialistai, jaunimas; mažiau išlaidų } \\
\text { darbuotojų paieškai; didesnis darbuotojų lojalumas, geresnè } \\
\text { darbuotojų sveikata. }\end{array}$ \\
\hline Pirkèjai & $\begin{array}{l}\text { Perėjimas prie etiško vartojimo; mažiau ginčų; geresnė reklama; } \\
\text { apsaugota reputacija; prekės ženklo kokybės pripažinimas. }\end{array}$ \\
\hline Tiekèjai & $\begin{array}{l}\text { Didesnis pasitikèjimas; lankstesni santykiai; teikiama } \\
\text { pirmenybe. }\end{array}$ \\
\hline Vyriausybė & $\begin{array}{l}\text { Palankesnis prekybos režimas; mažiau teisinių ginčų; } \\
\text { efektyvesnis bendravimas su socialinės politikos institucijoms. }\end{array}$ \\
\hline Aplinka & $\begin{array}{l}\text { Mažiau teisinių ginčų; geresnis ịvaizdis visuomenèje, geresnè } \\
\text { darbo aplinka, darbuotojų sveikata. }\end{array}$ \\
\hline
\end{tabular}

Globaliam įmonių socialinès atsakomybès vertinimo požiūriui galima būtų priskirti Kaganą et al. (2003), kuris teigia, jog vykdant tarptautinę plètrą, tam tikrais atvejais yra būtina sąlyga priklausyti tarptautinei organizacijai ar 
bendruomenei, vienijančiai socialiai atsakingas įmones pasaulyje (pvz., UN Global Compact, Global Report Initiative). Tuo tarpu Dhimanas (2008) akcentuoja ne išorès poveikị, o daugiau vidinę organizacijos motyvaciją organizacija negali klesteti, jeigu nesugeba tarnauti visuomenei.

Nors İSA vertinama pagal ịvairias suinteresuotąsias šalis, tačiau iš finansuotojų (komercinių bankų) pusès tokie tyrimai vis dar labai riboti. Nors, pavyzdžiui, Čiegis ir Grunda (2007) išskiria kreditorius kaip atskirą suinteresuotą šalị, tačiau nèra iki galo aišku, ar akcentuojami ịmonès kreditoriai - tiekejjai, ar kreditoriai - finansuotojai (komerciniai bankai). Dažniausiai finansuotojai apskritai labai retai išskiriami kaip atskira ịmonių socaline atsakomybe suinteresuota šalis. Tschoppas ir Nastanki (2014) išskiria kreditorius kaip tiesiogiai suinteresuotą šalị, tačiau ne kaip pačius svarbiausius autorių nuomone, svarbiausios suinteresuotos šalys yra dabartiniai i̇monès investuotojai, i̇monès vadovybė ir darbuotojai, o tik po to seka visos kitos suinteresuotos šalys (tiekejai, kreditoriai, klientai ir pan.). Taip pat svarbu paminèti tai, jog autoriai tokią suinteresuotų šalių klasifikaciją sieja ne su pačia imoniu socialine atsakomybe, o daugiau su socialine atskaitomybe. Kitas autorius (Clarke 2007) neišskiria kreditorių ar finansuotojų kaip atskiros grupès, o bendrai investuotojų ir akcininkų grupę ịvardija kaip vieną labiausiai suinteresuotų įmonès socialine atsakomybe šalių.

Tačiau, nepaisant to, kitų sričių (finansinių vertinimo metodų parinkimo, finansinès strategijos) tyrëjai (Dagilienė 2008, Bender 2002), kurių mokslinės tematikos artimos šio darbo tyrimui, išskiria kreditorius kaip tiesiogiai suinteresuotą įmonès veikla bei jos rezultatais šali. Dagilienè (2014) išskiria iš viso 8 suinteresuotas įmonès veikla bei veiklos rezultatais šalis: investuotojai, kreditoriai, vartotojai, visuomenè, vadovai, tiekèjai, darbuotojai, valstybinès institucijos. Taigi, siekiant praplèsti iki šiol atliktus mokslinius tyrimus İSA vertinimo iš finansuotojų pozicijos srityje, toliau darbe ypatingas demesys bus skiriamas būtent finansuotojams (komerciniams bankams).

\subsection{Imonių socialinès atsakomybès kompleksinio vertinimo sistemos teorinio pagrindo formavimas}

\subsection{1.[6 ąsaja su ịmonés YHINQRVILQDQVQDVIUH X XEVIV}

Kaip jau buvo minèta, įmonių socialinė atsakomybė ir jos nauda dažnai vertinama pagal ịmonès finansinius rezultatus ar rodiklius. Vienas svarbiausių mokslinių klausimų yra, kas sieja šiuos du dalykus - ar finansiniai rezultatai daro ịtaką ịmonių socialinei atsakomybei, ar socialinė atsakomybė veikia 
finansinius rezultatus. Nors kai kurie mokslininkai tvirtina, jog ryšys tarp šių dviejų objektų yra vis dar gana neaiškus (Jothi 2013), vis dèlto daugelis mokslininkų identifikuoja, jog egzistuoja ryšys tarp socialinès atsakomybès ir finansinių rezultatų (Torugsa et al. 2012, Skare 2011, Lech 2013, Cavaco 2014, Rodgers 2013, Xiantao 2014, McPeak 2012, Attig et al. 2013, Jiraporn et al. 2014). Daszynska-Zygadlo et al. (2016) akcentuoja, jog ryšio stiprumas labiausiai priklauso nuo pramonès sektoriaus, kuriame įmonè vykdo veiklą. Torusgsa et al. (2012) šị ryši grindžia didesne produktų ar paslaugu diferenciacija, pagerèjusiu gamybos efektyvumu, sumažèjusiomis operacinès veiklos išlaidomis (angl. operation costs). Skare (2011) savo darbe iškèlè hipotezę, jog socialiai atsakingų i̇monių finansiniai rezultatai buvo geresni, lyginant su įmonėmis, kurios nèra socialiai atsakingos. Hipotezė buvo patvirtinta pasitelkus regresinę analizę, kuri parodė stiprų ryši tarp ịmonių finansinių rezultatų ir įmonių socialinès atsakomybès. Be to, tyrimas parodè, jog socialiai atsakingos įmonès turi šešis kartus didesnę tikimybę pasiekti geresnių finansinių rezultatų nei įmonès, kurios nèra socialiai atsakingos. Lecho (2013) atliktame tyrime ryšys analizuotas remiantis suinteresuotų šalių teorija, o empirinėje dalyje - pagal pagrindinius pelningumo rodiklius - ROA ir ROE. Rodgersas (2013) taip pat remiasi suinteresuotujų šalių teorija, o jo atlikti empiriniai tyrimai parodè, jog egzistuoja ryšys tarp ịmonių socialinès atsakomybės ir įmonès vertès. Be to, investuotojai teigiamai vertina ịmonès socialines pastangas.

Taigi, apibendrinant linkstama prie išvados, jog įmonių socialinè atsakomybė pagerina arba teigiamai veikia ịmonès finansinę būklę ir jos rinkos vertę. Xiantao (2014), atlikęs tyrimą 30 naftos bendrovių Kinijoje, patvirtino, jog įmonių socialinè atsakomybe yra susijusi su įmonių finansiniais rezultatais. Mokslininkas pabrěžia, jog i̇monès ịsipareigojimas vadovautis socialine atsakomybe savo veikloje pagerina jos finansinius rodiklius (tokius kaip ROE, padidina pelno maržą). McPeakas (2012) savo ankstesniais tyrimais ir vienu naujausių tyrimų listinguojamose ịmonėse nustaté, jog socialiai atsakingų imonių akcijos yra stabilesnès ir linkusios augti bei generuoja ženkliai didesnę grąžą investuotojams. Tam, kad įmonè būtų sẻkminga, ji turi siekti efektyvių rezultatų socialinès atsakomybès veikloje, kad juos galètų matyti ir įvertinti visuomenè, klientai ir pati įmonè.

Kiti mokslininkai, patvirtinę egzistuojantị ryšį tarp įmonių socialinès atsakomybès ir i̇monių finansinių rezultatų, nustatè, jog imonių socialinè atsakomybè atlieka dar svarbesnị vaidmeni visos ịmonès lygmeniu. Mokslininkas Santoso (2014) nustatė ne tik egzistuojantị ryšị tarp İSA ir ịmonés veiklos rezultatų, bet ir ịrodè ryšį tarp įmonès dydžio ir İSA - kuo didesnè i̇monè, tuo platesnis ịmonès veiklos spektras socialinès atsakomybės srityje. Dar daugiau, dèl İSA ryšio su įmonès veiklos rezultatais siūloma İSA įtraukti ị pagrindinę ịmonès strategiją - noredama pasiekti optimalių rezultatų, įmonè turi 
turèti aiškią ISA programą, kuri savo ruožtu ves ị tvarią plètrą ir darnų vystymąsi. Adewale (2014) teigia, jog İSA turètų būti vertinama kaip vienas iš imonès prioriterinių dalykų, kuris nepriklausomai nuo būtinų papildomų investicijų kiekio turi būti vertinamas kaip investicija su ilgalaike grąža bei irankis siekiant kitų organizacijos tikslų.

Kai kurie mokslininkai (Oh 2015) teigia, jog neužtenka identifikuoti ryši ne mažiau svarbus yra ir jo stiprumas. Ohas (2015) savo tyrimuose nustate ne tik teigiamą İSA ịtaką įmonių veiklos rezultatams, bet ir tai, kad İSA ịtaka ir ryšio stiprumas gali skirtis dèl pramonès sektoriaus, kuriame įmonè vykdo veiklą, ypatumų.

Kitų mokslininkų (Fauzi 2009, McWilliams 2000) atlikti tyrimai patvirtino, jog ISSA neturi jokios ịtakos ịmonès veiklos rezultatams arba ta ịtaka yra neutrali.

Nors daugelis mokslininkų, tyrèjų ir praktikų nurodo, jog İSA vienaip ar kitaip veikia ịmonių veiklos rezultatus, kai kurie iš jų tiria būtent atvirkštinị ryšị (Arsoy 2012, Peloza 2008, Fauzi, Idris 2009, Waddock, Graves 1997, Scholtens 2006). Arsoy (2012), atlikęs tyrimą turkiškose įmonèse, nustatė atvirkštinį ryšį imonių, kurių finansiniai rezultatai geresni, socialinès atsakomybės lygis yra aukštesnis. Anot Peloza (2008), nèra nuoseklaus ir aiškaus ryšio tarp İSA ir i̇monès veiklos rezultatų, nes ne visi įmonių vadovai prioretizuoja būtent ekonominius tikslus - kartais finansinè grąža atlieka tik antraeili vaidmenį. Fauzi, Idrisas (2009) analizuoja dvi skirtingas teorijas (angl. Slack Resource theory, Good Management theory), kuriomis remdamasis nustatė egzistuojanti atvirkštinị ryšị - ịmoné, turẻdama finansinių galimybių, savo veikloje gali integruoti ir İSA. Ankstesni tyrimai taip pat buvo labai svarūs - Waddockas ir Gravesas (1997), listinguojamų USA akcijų biržoje (S\&P500) tirdami 469 įmones nustatè, kad jų socialinè atsakomybè priklauso nuo jų finansinių rezultatų. Autoriai pateikè išvadą, jog kuo įmonè finansiškai stipresnè, tuo ji turi didesnę laisvę ir galimybių investuoti ị İSA.

Taigi, kaip parodė moksliniai tyrimai, egzistuoja abipusis ryšys - İSA ir imonių finansiniai rezultatai sąveikauja tarpusavyje ir stiprina vienas kitą, o Waddockas ir Gravesas ryši apibūdina „dorovès ratu“ (angl. virtuous circle) (Dean 1998, Waddock, Graves 1997) (1.9 pav.). Naujausi moksliniai tyrimai ir mokslininkai taip pat patvirtina ši teigini (Rodriguez-Fernandez 2016), - jog socialinė atsakomybe užtikrina didesni pelningumą, o pelningumas - didesnę socialinę atsakomybę. Ši išvada buvo pagrista Ispanijoje listinguotų įmonių patirtimi, nustačius ryši tarp jų socialinės atsakomybės rodiklių (tokių kaip GRI vertinimas ar DJSI indeksas) ir finansinių rodiklių (ROA, ROE ir pan.). Kadangi pagal mokslinių tyrimų rezultatus įmonès finansiniai rezultatai $\rightarrow$ İSA ryšys, tikètina, silpnesnis nei ryšys ISA $\rightarrow$ finansiniai rezultatai, grafiškai ,dorovès ratas" galètų atrodyti taip: 


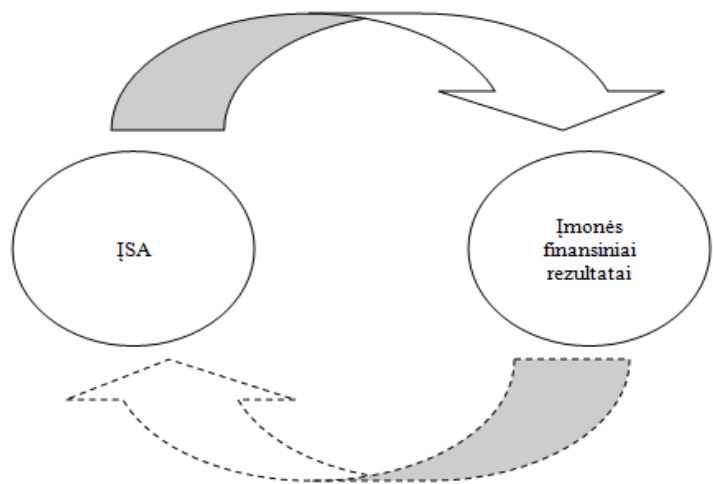

1.9 pav. Waddocko ir Graveso „dorovès ratas“ (šaltinis: autorè)

Fig. 1.9. Virtuous circle by Waddock and Graves (source: author)

Vienas ịdomiausių atliktų tyrimų yra Jacksono (2009) pasiūlytas modelis matrica, kuri apima abu dalykus: İSA ir ịmonès finansinius rezultatus. Matricą sudaro keturi galimi lygiai (angl. Non-Profit GREEN, Repressive YELLOW, Progressive BLUE, Aggressive BLACK), kurie apima 5 finansinių rodiklių grupes ir 4 socialinès atsakomybès rodiklių grupes. Tačiau vienas didžiausių šio modelio trūkumų, - jog matrica visiškai neapima ryšio tarp İSA ir įmonių finansinès veiklos, kas yra itin aktualu ịvairiems mokslininkams ir tyrëjams pastaruosius kelis dešimtmečius.

\subsubsection{Trijų ramsčių teorija}

Trijų ramsčių teorija (angl. Triple bottom line arba TBL) nuo pat jos atsiradimo (1990 m. sukūrè Elkingtonas) iki pat šių dienų yra tarsi rèmai, kuriais galima ịvertinti įmonès veiklos rezultatus. Trijų ramsčių teorija organizacijos sėkmę siūlo vertinti pagal tris pagrindinius parametrus - socialinị, ekologinị (aplinkosaugini) ir ekonomini (Goel 2010). Goelis (2010) trimati veiklos minimumą apibūdina kaip valdymo ir veiklos vertinimo metodą, kuris pabrèžia svarbą ir veiklos rezultatus ekonominèje, aplinkosauginèje ir socialinejje srityse. Taigi ši koncepcija yra neatsiejama nuo įmonès vaidmens, atsakomybių bei veiklos rezultatų.

Kituose mokslo ir praktiniuose šaltiniuose Trijų ramsčių koncepcija aiškinama per tris pamatinius elementus: žmones (angl. People), planetą (angl. Planet) ir pelną (angl. Profit) (Alhaddi 2014, The Economist 2009, Atsakingas verslas 2013) (1.6 lentelè). 
1.】 lentelè. Imonių socialinè atsakomybė pagal Trijų ramsčių teoriją (šaltinis: Atsakingas verslas 2013)

Table 1. . Corporate Social Responsibility based on TBL concept (source: Atsakingas verslas 2013)

\begin{tabular}{|c|c|c|}
\hline $\begin{array}{l}\text { Ekonominė atsakomybè } \\
\text { (angl. PROFIT) }\end{array}$ & $\begin{array}{l}\text { Etinè / socialinè } \\
\text { atsakomybe } \\
\text { (angl. PEOPLE) }\end{array}$ & $\begin{array}{c}\text { Ekologinè / aplinkosauginè } \\
\text { atsakomybė } \\
\text { (angl. PLANET) }\end{array}$ \\
\hline $\begin{array}{ll}\text { - } & \text { Rentabili veikla - } \\
& \text { pelningumas; } \\
\text { - } & \text { Konkurencingos prekès } \\
& \text { ir paslaugos; } \\
\text { - } & \text { Valdymo efektyvumas; } \\
\text { - } & \text { Savo veiklos sąnaudų } \\
& \text { neperkėlimas kitiems } \\
& \text { suinteresuotiesiems; } \\
\text { - } & \text { Energijos bei energiją } \\
& \text { eikvojančiu gamybos } \\
& \text { elementų taupymas; } \\
\text { - } & \text { Tiekimo patikimumas; } \\
\text { - } & \text { Finansinès rizikos } \\
& \text { valdymas. }\end{array}$ & 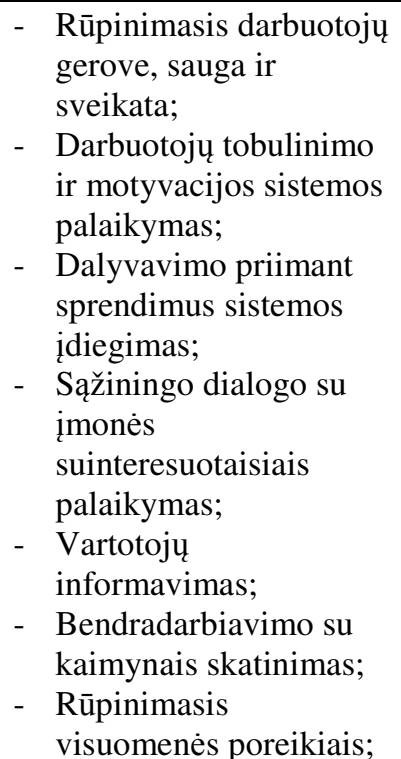 & $\begin{array}{l}\text { - Aplinkosaugos teisės } \\
\text { aktu išmanymas ir } \\
\text { laikymasis; } \\
\text { - İmonės veiklos poveikis } \\
\text { aplinkai (žaliavu } \\
\text { naudojimas, aplinkos } \\
\text { tarša); } \\
\text { - Ekologinės rizikos } \\
\text { valdymas, taršos } \\
\text { mažinimas; } \\
\text { - Nuolatinis gamtą } \\
\text { tausojančiu veiklos } \\
\text { rodiklių stebejjimas ir } \\
\text { atitinkamų verslo } \\
\text { procesų tobulinimas; } \\
\text { - Reikalingų permainų } \\
\text { numatymas ir jų } \\
\text { laikymasis. }\end{array}$ \\
\hline
\end{tabular}

Elkingtono Trijų ramsčių teorijos pasekejjai Savitzas ir Weberis (2006) pateikè savo knygoje tipinius ekonominès, aplinkos ir socialinès sričių kriterijus, kurie atitinkamai sudaro įmonių socialinę atsakomybę (1.7 lentelè).

1. lentelè. Tipiniai kriterijai pagal Trijų ramsčių teoriją (šaltinis: Savitz, Weber 2006) Table 1. . Typical criteria by Triple Bottom Line (source: Savitz, Weber 2006)

\begin{tabular}{|c|c|c|}
\hline Ekonominė atsakomybė & $\begin{array}{l}\text { Ekologinè / aplinkosauginè } \\
\text { atsakomybė }\end{array}$ & $\begin{array}{l}\text { Etiné / socialinè } \\
\text { atsakomybe் }\end{array}$ \\
\hline Pardavimai, pelnai, ROI & Oro kokybè & Darbuotojų teisès \\
\hline Mokesčiai & Vandens kokybè & Bendruomeniu poveikis \\
\hline Pinigų srautai & Energijos sunaudojimas & Žmogaus teisès \\
\hline Darbo vietu sukūrimas & Atliekų perdirbimas & $\begin{array}{l}\text { Atsakomybė už gamini / } \\
\text { paslaugą }\end{array}$ \\
\hline
\end{tabular}


Analizuojant Trijų ramsčių teoriją, labai svarbu suvokti minètų trijų sričių tarpusavio sąsają (ryši), kuri, anot mokslininkų, bendrai sudaro įmonių socialinès atsakomybès sampratą. Be to, kaip teigia Rodriguezas et al. (2002), TBL koncepcija yra pagrịsta pripažinimu, kad verslo tvarumas ir darnumas (angl. sustainability) priklauso nuo teigiamų ekonominių, aplinkosauginiu ir socialinių išteklių pokyčių.

Mokslininkai praktinị Trijų ramsčių teorijos igyvendinimą dažniausiai analizuoja keliais pagrindiniais aspektais:

- tam tikrame pramonès sektoriuje: Onatas et al. (2014) savo tyrime siekia nustatyti aktualius trimačio minimumo kriterijus, kurie yra aktualūs JAV statybos sektoriuje (gyvenamujų namų, komercinių pastatų srityjekonstrukcijų statybos, eksploatavimo ir šalinimo etapuose); JAV konstrukcijų sektoriaus tvarumo ịvertinimas, remiantis TBL kriterijais, yra analizuojamas ir Kucukvaro, Tatari (2013); Shnayderis et al. (2015) savo tyrime analizuoja, kaip taikomi ISSA kriterijai pagal kelias schemas: a) pagal TBL metodą; b) ar İSA pastangos reikalauja ịmonejje radikaliu pokyčių, ar tai vyksta įmonès išoreje - per tiekimo grandinę c), ar įmonès pastangos ISSA srityje yra papildomos, ar tai normali verslo praktika ir imonè bet kokiu atveju tokiais kriterijais vadovautųsi savo veikloje;

- tam tikroje įmonès veiklos grandyje: Hollosas et al. (2012) tiria, koki efektą įmonès veiklos rezultatams duoda trimačio veiklos minimumo kriterijų taikymas bendradarbiaujant su tiekèjais;

- konkrečių įmonių / situacijų analizè: Dhimanas (2008) analizuoja ir pateikia kelių žinomų pasaulinių kompanijų, tokių kaip „Clorox“, „Timberland“, „Toyota“"ir GE, trimačio veiklos minimumo kriterijų igyvendinimą savo veikloje; Goelis (2010) analizuoja TBL aspektus Indijos kompanijoje „Jubilant Organsys LTD.“, kuri dar ir rengia tvarumo ataskaitas vertindama savo socialinès atsakomybès veiklą; Slaperis, Hallas (2011) TBL taikymą analizuoja remdamiesi keliais konkrečiais pavyzdžiais - projektais ir įmonėmis.

Pagrindine moksline ir praktinė problema ir iššūkis, su kuria susiduriama vertinant TBL, yra vieno matavimo vieneto nebuvimas - pvz., pelną galima ịvertinti doleriais ar kitokia valiuta, tačiau kaip įvertinti socialinị kapitalą? Galimi keli TBL vertinimo metodai - paverčiant pinigais (kokia nors konkrečia valiuta), indeksuojant kriterijus. Tačiau tiek vienas, tiek kitas vertinimo metodas laikomi ne visai tinkamais, nes nèra aišku, kaip reikètų pinigine išraiška įvertinti filosofinius dalykus ar kitokius sunkiau apibréžiamus. Kalbant apie indeksus, nèra aišku, kaip reikètų nustatyti jų svorius tarpusavyje arba nuspręsti, kuris iš jų svarbiausias. Taigi, vieningos ir universalios TBL kriterijų vertinimo sistemos nèra sukurta. Taip pat nesukurta vieninga visuotinai priimta sistema, kuri galètu 
ịvertinti TBL kriterijus. Kita vertus, tai galima vertinti kaip galimybę, leidžiančią naudotojui (vartotojui) adaptuoti TBL struktūrą pagal individualius poreikius - ịvairiems projektams ar politikoms (pvz., investicijos ị infrastruktūrą ar švietimo programos) ar skirtingoms geografinèms riboms (miestui, regionui ar šaliai). Kitaip sakant, projekto lygis, projektas ir geografinè apimtis lemia tai, kokius kriterijus reikètų įtraukti ị TBL vertinimus. Apibendrinant galima teigti, jog priemonių rinkinys, kuriuo bus vertinami TBL parametrai, yra nustatomas individualiai, atsižvelgiant į:

- tai, kas svarbu interesų šalims;

- eksperto, atliekančio tyrimą, tikslus;

- galimybes surinkti duomenis tyrimui (Slaper, Hall 2011).

Be jau išvardytų privalumų, Elkingtono Trijų ramsčių teorija sąlygojo ir tokių iniciatyvų kaip GRI ar Dow Joneso tvarumo (angl. sustainability) indekso atsiradimą.

\subsubsection{Finansinių rodikliụ integravimas [iYHURQP RMMAP ą}

Tiek investuojant ị ịmonę, tiek ją finansuojant, visada tikimasi, jog rezultatas bus pelningas - tiek pačiai įmonei, tiek investuotojui ar finansuotojui. Tačiau kai kalbama apie įmonių socialinę atsakomybę, finansinès naudos ịvertinimas visada buvo didelis iššŭkis mokslininkams ir pačioms įmonėms (Chang, Kuo 2008). Vieni mokslininkai İSA naudingumą vertina pagal pelningumo rodiklius, tokius kaip ROE (kapitalo grąža), ROA (turto arba investicijų grąža), ROS (pardavimų grąža arba pelningumas). Kiti tyrèjai, siekdami nustatyti ryši tarp įmonių socialinès atsakomybès ir finansinių rezultatų, vertina akcijų kainą arba tiesiog investicinio portfelio, sudaryto iš tokių įmonių, grąžą (Chang, Kuo 2008). Investuojant ị socialiai atsakingas įmones (angl. Socially responsible investing SRI) siekiama ne tik finansinès, bet ir socialinès naudos suinteresuotų šalių atžvilgiu (Glac 2009). Tad investuotojai arba fondai, sudarydami investicijų portfelius, pirmenybę teikia ịmonėms, kurios savo veikloje vadovaujasi socialinès atsakomybès kriterijais, bei atitinkamai eliminuoja tas ịmones, kurios neatitinka İSA kriterijų. Pastarosios įmonès dažniausiai veikia azartinių lošimų, ginklų, tabako ar alkoholio pramonèse (Carter 2007). Remdamiesi atliktais empiriniais ir praktiniais tyrimais, mokslininkai (Hayes 2005, Barnett, Salomon 2005, Benson et al. 2006, Kalwarski 2008, Cortez et al. 2009, Jeroen, Kees 2009) ne kartą bande ịrodyti, jog toks investavimas gali generuoti kur kas geresnius rezultatus negu paprasti investiciniai portfeliai ar fondai.

Nors mokslinių studijų ir tyrimų, skirtų investavimui ị ISA arba investavimui i socialiai atsakingus investicinius fondus, atlikta nemažai, investavimas iš finansuotojo pozicijos ị socialiai atsakingą verslą - vis dar gana 
nauja mokslinių tyrimų sritis. Daugiausia tik naujausiuose moksliniuose tyrimuose (Gutierrez-Nieto et al. 2016) ieškoma praktinių būdų, kaip reikètų ịvertinti ịmonių socialinę atsakomybę finansuotojo požiūriu. Ribotus tyrimus šioje srityje galbūt sąlygoja ir informacijos trūkumas.

Kadangi toliau šiame darbe įmonių socialinė atsakomybè tiriama iš finansuotojų pozicijos, atitinkamai siūloma vadovautis TBL filosofija, pagal kurią ISA kriterijų sąranka turi būti sudaroma individualiai, pagal poreikius, tyrëjo tikslus ir duomenu surinkimo galimybes. Todèl, remiantis Čiegio ir Grundos (2007) požiūriu, jog vienas esminių ir pamatinių darnaus vystymosi principų yra imonès veiklos pelningumas, tradicinę ISA sampratą, kuri dažniausiai apima aplinkosauginius, etinius bei socialinius kriterijus, siūloma papildyti ekonominiais - finansiniais kriterijais.

İvairūs mokslininkai (Monea 2009, Keskin 2013, Kotane, Kuzmina Merlino 2012, Kneževic et al. 2011, Krivka, Stonkutė 2015, Wang, Lee 2010, Šapaliené et al. 2014, Daujotaite 2006) pateikè gana skirtingas svarbiausių (pagrindinių) finansinių rodiklių klasifikacijas, kurių mokslinį pagrindą suformavo paprasti bei AHP (angl. Analytical Hierarchy Process) metodu apdoroti ekspertiniai vertinimai, analogiškų situacijų analizè, mokslinès ir metodinès literatūros analizès.

Kiti mokslininkai aktualius rodiklius arba jų grupes išskirsto pagal naudos gavejjus arba pagal tų rodiklių naudotojus. Juozaitienè (2007) savo metodinèje literatūroje pateikia finansinių rodiklių pasirinkimą pagal skirtingas interesų šalis (1.8 lentelè).

1. lentelè. Finansinių rodiklių pasirinkimas atsižvelgiant ị informacijos vartotojus (šaltinis: Juozaitienè 2007)

Table 1. . Financial ratios according to the information users (source: Juozaitiene 2007)

\begin{tabular}{lll}
\hline \multicolumn{1}{c}{ Bankai } & \multicolumn{1}{c}{ Investuotojai } & \multicolumn{1}{c}{$\begin{array}{c}\text { Negrąžintinos paramos } \\
\text { teikejjai }\end{array}$} \\
\hline $\begin{array}{l}\text { Imonės likvidumo, } \\
\text { pelningumo, } \\
\text { skolos rodikliai }\end{array}$ & $\begin{array}{l}\text { Imonės likvidumo, } \\
\text { pelningumo, } \\
\text { skolos rodikliai }\end{array}$ & $\begin{array}{l}\text { Socialiniai-ekonominiai } \\
\text { rodikliai }\end{array}$ \\
\hline EBITDA, ROI, ROE & $\begin{array}{l}\text { EBITDA, ROI, ROE, } \\
\text { ROA }\end{array}$ & Naujos darbo vietos \\
\hline- & $\begin{array}{lll}\text { Projekto rodikliai: } \\
\text { IRR, NPV metodai }\end{array}$ & Projekto rodikliai: DCF, \\
& IRR, NPV metodai \\
\hline
\end{tabular}


Antanavičienè, Šimelytė (2014) finansinius rodiklius taip pat grupuoja pagal finansinès analizès rezultatų vartotojus: savininkus, kreditorius ir vadybininkus. Anot autorių, kreditoriams aktualūs rodikliai yra šie: bendrojo likvidumo koeficientas, greitojo likvidumo koeficientas, skolų ir turto santykis, skolų ir nuosavo kapitalo santykis, palūkanų padengimo koeficientas, ilgalaikių isipareigojimų padengimo koeficientas. Kitas autorius (Elena 2012) prie jau išvardytų finansinių rodiklių, aktualių finansuotojams, dar prideda ịmonės likvidacinę vertę, pinigų srautų analizę, skolų ir viso kapitalo santykị, pelno dalį, tenkančią vienam akcijos vienetui.

Apibendrinant išanalizuotą užsienio ir lietuvių mokslinę literatūrą apie aktualius finansinius rodiklius, galima teigti, jog finansuotojams svarbiausios yra šios finansinių rodiklių grupės:

- pelningumo rodikliai;

- likvidumo rodikliai;

- skolų aptarnavimo rodikliai;

- kiti finansiniai rodikliai: EBITDA, ROA, ROI, ROE.

\subsection{Pirmo skyriaus išvados ir disertacijos uždaviniụ formulavimas}

1. Visais laikais bankai atliko itin svarbų vaidmeni valstybių ir tarpvalstybinejje ekonomikoje. Tačiau labiausiai finansų rinkų poveikis ekonomikai išryškejo $2008 \mathrm{~m}$., kai pasauli sukrètė finansų krizè, prasidejjusi būtent finansų rinkų epicentre. Didžiulis ekonominis nuosmukis buvo tarsi indikatorius, jog bankų veikla nepakankamai tvari. Taigi, bankai, siekdami išvengti panašių finansų krizių ateityje bei atgauti ịmonių ir žmonių pasitikejjimą, èmèsi vis labiau taikyti socialinès atsakomybės aspektus savo veikloje. Vienas dažniausiai taikomų būdų praktikoje, siekiant tvarios bankininkystès tikslų ir turinčių itin dideli poveiki banko veiklos rezultatams finansuojamų įmonių socialinės atsakomybès vertinimas. Bankų poreikis vertinti finansuojamų İSA, geriau įvertinti galimas rizikas bei efektyviau paskirstyti turimus išteklius - visa tai itin padidino i̇monių socialinès atsakomybės vertinimo klausimo aktualumą.

2. Literatūros analizè parodè, jog İSA samprata nuolat keitèsi, išryškindama dvi pagrindines tendencijas, - kai reaktyvus įmonių elgesys tapo proaktyvia pasauline tendencija, arba, kai ideologija virto būtinybe. Tačiau šie pokyčiai nesuformavo vieningos įmonių socialinès atsakomybès sampratos, anaiptol, daugelis mokslininkų 
prièjo prie išvados, jog įmonių socialinė atsakomybė vis dèlto yra individualus kiekvienos organizacijos reikalas.

3. Labai dažnai İSA yra siejama su tam tikrais kriterijais arba atitikimu jiems. Kaip nèra suformuoto vieno İSA sampratos apibrèžimo, taip nèra vienos kriterijų sąrankos, kuri galètų būti naudojama universaliai. Be to, mokslinès literatūros analizè atskleidè, jog İSA gali būti vertinama ịvairiais metodais - pradedant nuo naudos, kurią patiria skirtingos įmonés veikla suinteresuotos šalys iki vertès kūrimo grandinès sudarymo. Tačiau dažniausiai siūlomi vertinimo metodai yra kokybiniai, o finansuotojai nèra išskiriami kaip suinteresuota šalis. Taigi, kyla poreikis suformuoti kiekybiniais metodais grịstą vertinimo sistemą, skirtą finansuotojui.

4. ISSA kompleksinio vertinimo sistemai suformuoti sudarytas teorinis pagrindas: Trimačio veiklos minimumo (angl. Triple Bottom Line) teorija, kuri buvo papildyta aktualiomis finansinių rodiklių grupemis (pelningumo, likvidumo, skolų aptarnavimo) bei praktinèmis rekomendacijomis įmonių finansavimo srityje.

5. Siekiant disertacijos tikslo sukurti ISSA kompleksinio vertinimo sistemą, skirtą finansuotojui, literatūros analizè leidžia formuoti tolesnius uždavinius: sudaryti aktualių kriterijų sąranką, parengti sistemos skaičiavimo algoritmą bei numatyti daugiakriterinius vertinimo metodus, kurie bus naudojami sudarant sistemą (teorinis modeliavimas), praktiškai sumodeliuoti ISA kompleksinio vertinimo sistemą bei patikrinti jos tinkamumą vertinant pasirinktas įmones. 



\section{2}

\section{Imonių socialinès atsakomybès kompleksinio vertinimo sistemos teorinis modeliavimas}

İvertinus įmonių socialinès atsakomybès sampratos bei i̇monių socialinės atsakomybès vertinimo specifiką ir atsižvelgiant į finansuotojų poreiki İSA vertinti kompleksiškai ir sistemingai, šioje darbo dalyje teoriškai suformuojama ISA kompleksinio vertinimo sistema, skirta finansuotojui. Skyriaus tema parašytas ir moksliniame žurnale publikuotas mokslinis straipsnis (Slapikaitė, Tamošiūnienè 2017).

\subsection{Imonių socialinès atsakomybẻs kompleksinio vertinimo sistemos algoritmo sudarymas}

Pirmoje darbo dalyje apžvelgus Lietuvos ir užsienio mokslinę bei praktinę literatūrą apie įmonių socialinès atsakomybès sampratą ir imonių socialinès atsakomybès vertinimą, nustatytas poreikis sukurti İSA kompleksinio vertinimo sistemą, skirtą finansuotojui. Siekiant šio tikslo, sudarytas sistemos algoritmas, pateiktas 2.1 paveiksle. 


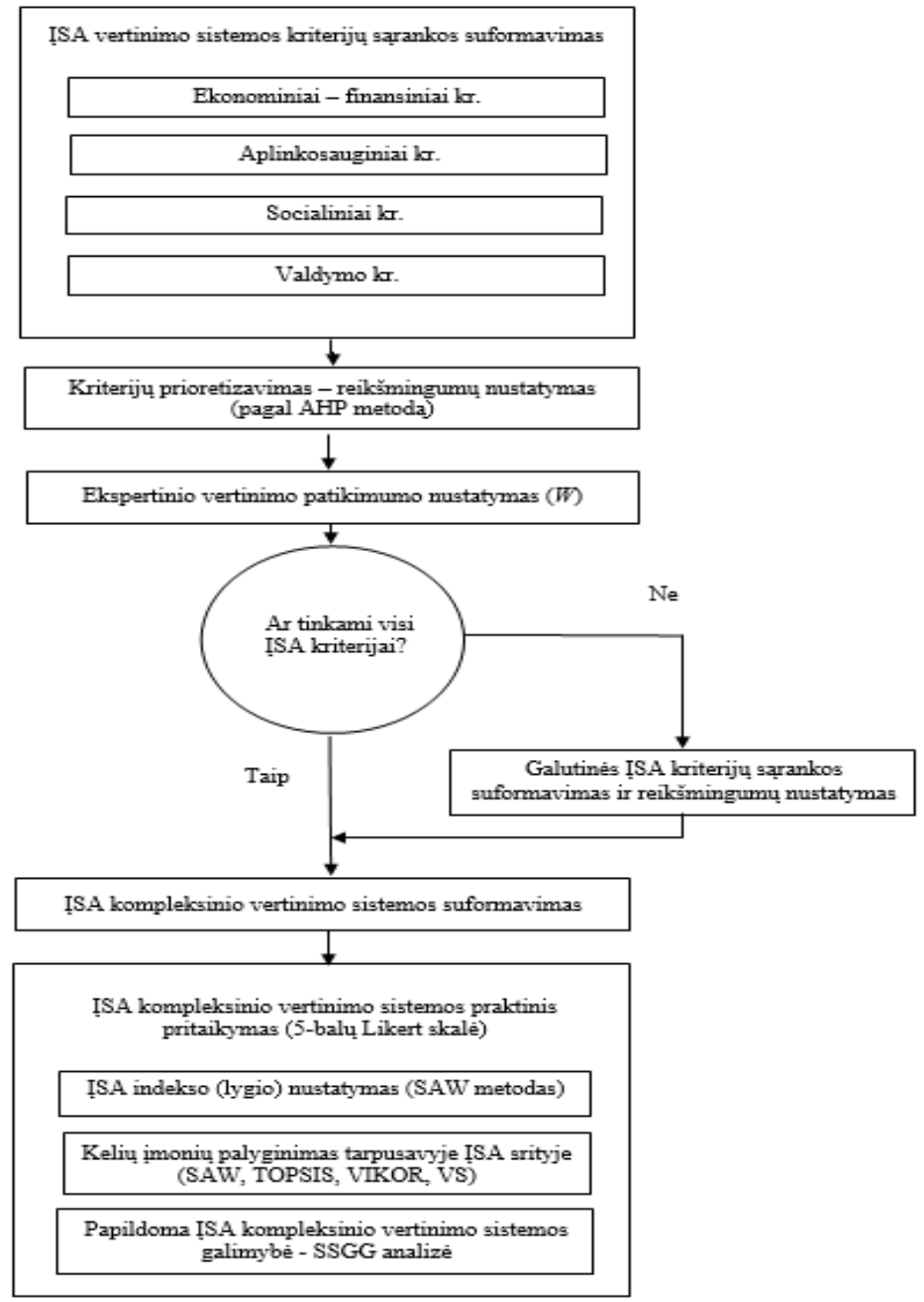

2.1 pav. İmonių socialinès atsakomybės kompleksinio vertinimo sistemos algoritmas (šaltinis: autorè)

Fig. 2.1. The algorithm of corporate social responsibility complex evaluation system (source: author)

IS kompleksinio vertinimo sistemos algoritmas apima kelis pagrindinius žingsnius:

- remiantis jau išnagrinèta moksline ir praktine literatūra, suformuojama galimai aktualių komerciniams bankams İSA kriterijų sąranka; 
- suformavus pradinę kriterijų sąranką, nustatomi kriterijų reikšmingumai;

- nustatomas ekspertinio vertinimo patikimumas (konkordacijos koeficientai) ir patikrinami jų reikšmingumai;

- nustačius kriterijų konkordacijos koeficientus, toliau įvertinama, ar visi kriterijai yra priimtini ir tinkami naudoti sistemoje;

- galiausiai suformuojama galutinė İSA kompleksinio vertinimo sistema bei perskaičiuojami kriterijų reikšmingumai;

- sistemos pritaikomumas patikrinamas praktiškai pasirinktų ịmonių pagrindu.

Numatoma, jog İSA kompleksinio vertinimo sistema, skirta finansuotojams, pasižymès universalumu: leis ne tik nustatyti vienos įmonès socialinès atsakomybès lygi, bet ir palyginti (suranguoti) kelias imones tarpusavyje. Be to, papildomai suteiks galimybę finansuotojui ịvertinti stipriąsias ar silpnasias i̇monès socialinès atsakomybès sritis, ižzelgti galimas rizikas ar, priešingai, ịžvelgti naujas bendradarbiavimo galimybes su įmone.

\subsection{Lietuvoje veikiančių komercinių bankụ brandumo lygio socialinès atsakomybès srityje nustatymas}

Komercinių bankų brandumo lygi socialinès atsakomybès srityje siekiama nustatyti tam, kad būtų galima praktiškai patvirtinti arba paneigti İSA kompleksinio vertinimo sistemos sukūrimo poreikị. Šiam tikslui pasiekti šioje tyrimo dalyje naudojamas ekspertinis vertinimas. Iš viso apklausta 13 ekspertų iš 5 skirtingų skandinaviško kapitalo bankų Lietuvoje (ekspertų grupe E1). Ekspertai daugiausia dirba bankų socialinès atsakomybès srityje, verslo finansavimo, verslo plètros, yra keli ekspertai iš rinkodaros bei privačių klientų aptarnavimo sričių.

Dabartinė Lietuvoje veikiančių komercinių bankų situacija vertinama, remiantis socialinès atsakomybès brandumo modeliu (angl. ESG maturity grid model), pagrįstu penkiais brandumo lygiais, numatytais metodikoje, skirtoje komerciniams bankams (REPORT 2014: Environmental, Social and Governance: Integration for Banks: a Guide to Starting Implementation). Bankų socialinès atsakomybès brandumo modeli sudaro 5 brandumo lygiai (B priedas):

1 brandumo lygis - reaktyvus socialinès atsakomybès valdymas;

2 brandumo lygis - galimybių išnaudojimas ir ad hoc (lot. ad hoc reiškia sprendimus, skirtus tik konkrečiai problemai ar užduočiai spręsti);

3 brandumo lygis - analitinis ir sisteminis;

4 brandumo lygis - integravimas ị kasdienę veiklą; 
5 brandumo lygis - rinkos lyderis ir formuotojas.

Mažiausias - 1 brandumo lygis išsiskiria primityviausiais požymiais. Kitaip sakant, ši brandumo lygi atitinkantis bankas siekia, kad nebūtų nutraukta ar kitaip apribota jo veikla. Kuo aukštesnis brandumo lygis, tuo didesnis banko sąmoningumas šioje srityje - pvz., 3 brandumo lygi atitinkantys bankai taiko pažangius patobulinimus (angl. incremental improvements), o aukščiausią3 brandumo lygi atitinkantys bankai yra aukščiausiame lygmenyje ir patys formuoja rinkos tendencijas šioje srityje.

Tiriant finansuotojų brandumo lygį socialinès atsakomybès srityje, analizè atliekama integruojant aplinkosauginius, socialinius ir valdymo (angl. environmental, social and governance arba ESG) faktorius bankų veikloje (REPORT 2014: Environmental, Social and Governance: Integration for Banks: a Guide to Starting Implementation).

Analizuojant bendrą bankų sąmoningumo lygị ( 2.2 pav.) socialinès atsakomybès srityje, daugiau nei pusè respondentų (54\%) tvirtina, jog sąmoningumas nuolat auga, beveik ketvirtadalis $(23 \%)$ respondentų banko sąmoningumą socialinès atsakomybès srityje vertina kaip daugiau nei vidutiniškai aukštą jų organizacija yra proaktyvi integruojant ESG kriterijus savo veikloje. Taip pat nemaža dalis respondentų (15\%) tvirtina, jog nors sąmoningumas jų organizacijoje vis didèja, tačiau ji vis dar labiau koncentruojasi tik i populiarius projektus (angl. must have).

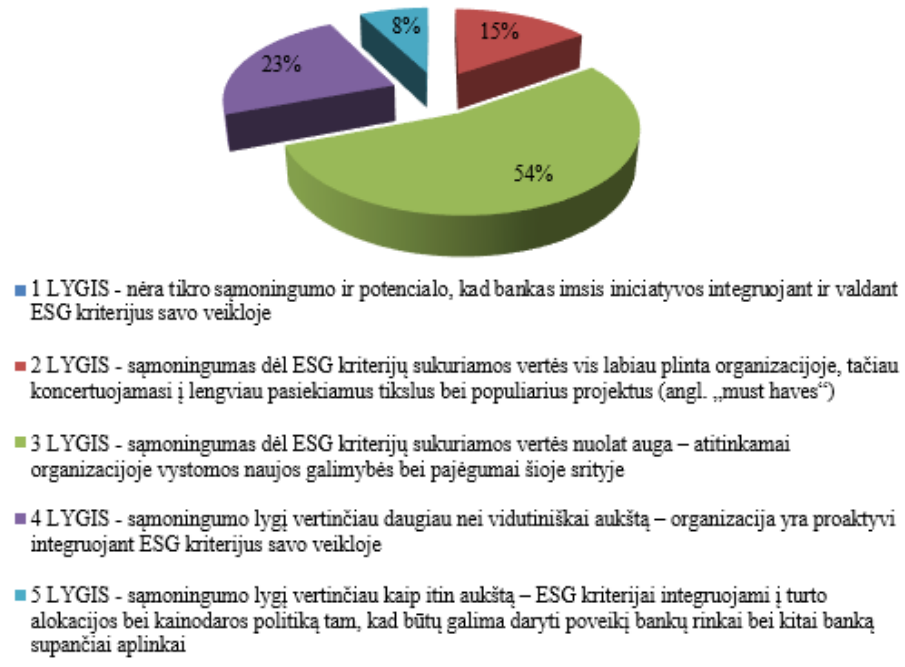

2.2 pav. Bankų sąmoningumo socialinès atsakomybès srityje lygis (šaltinis: autorè)

Fig. 2.2. Bank's level of consciousness in the field corporate social responsibility (source: author) 
Nors bankų sąmoningumo lygis socialinès atsakomybės srityje nuolat auga, vyrauja požiūris (46 \%) (2.3 pav.), jog bankas tikrai turi akivaizdžiai prisidèti prie visuomenès projektų (pvz., skatinant ir finansuojant ,žalius“ projektus). O šiek tiek mažesnè dalis (38 \%) respondentų tvirtina, jog socialinè atsakomybè turètų būti ne tik integruota ị rizikos valdymo procesus, bet ir naudojama kaip konkurencinio pranašumo šaltinis.
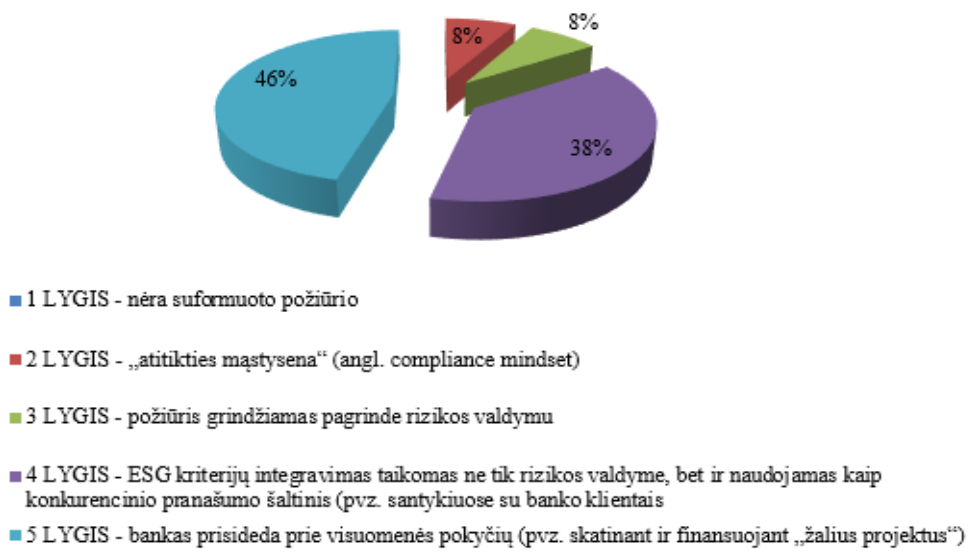

2.3 pav. Bankų požiūris ị socialinę atsakomybę (šaltinis: autorè)

Fig. 2.3. Banks' attitude towards corporate social responsibility (source: author)

Analizuojant socialinę atsakomybę per banko strategiją (2.4 pav.), didžioji dalis respondentų (46\%) atsakè, jog bankas ne tik valdo tiesioginị poveikị aplinkai, bet ir integruoja ESG faktorius ị pagrindinius banko veiklos procesus.
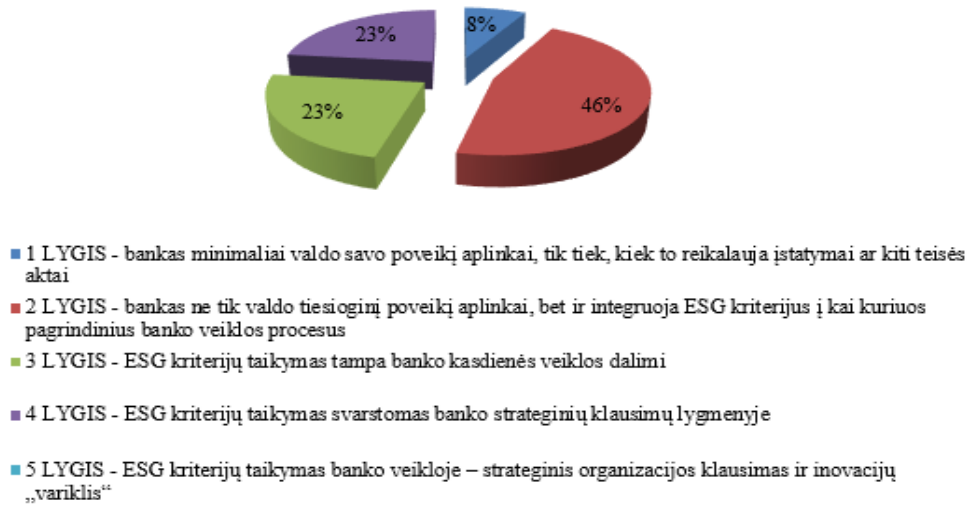

2.4 pav. Bankų strategija socialinès atsakomybès srityje (šaltinis: autorè)

Fig. 2.4. Banks' strategy towards corporate social responsibility (source: author) 
Beveik ketvirtadalis (po $23 \%$ ) respondentų atsaké, jog socialinès atsakomybès klausimai yra svarstomi banko strateginių klausimų lygmenyje arba ESG kriterijų taikymas vis labiau tampa bent jau kasdienès banko veiklos dalimi. Tačiau socialinė atsakomybė né viename banke kol kas nèra strateginis klausimas ir inovacijų ,variklis“.

Kalbėdami apie veiklos procesus (2.5 pav.), beveik trečdalis respondentų (31\%) tvirtino, jog bankas tik pradeda integruoti socialinę atsakomybę i dali rizikos valdymo, produktų kūrimo bei vystymo procesų. Kaip ir dèl banko strategijos, taip ir dèl veiklos procesų $23 \%$ respondentų tvirtino, kad jų bankas visiškai integruoja socialinès atsakomybès klausimus ị kasdienę banko veiklą procesus (nuo rizikos valdymo iki klientų aptarnavimo), tačiau jie kol kas nėra atitinkamai perprojektuoti ir nekuriami nauji. Kiti $23 \%$ respondentų teigé, jog vis dèlto ESG kriterijų integracijos lygis organizacijoje yra labai aukštas - banko veiklos procesai yra perprojektuojami arba netgi kuriami nauji verslo modeliai.

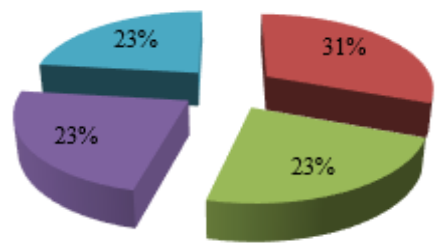

\footnotetext{
n 1 LYGIS - ESG kriterijai integruoti ị banko veiklos procesus minimaliai - tik tiek, kad būtụ galima atitikti istatymus ar kitus teisés altus

$=2$ LYGIS - bankas pradeda integruoti ESG kriterijus ị dalị rizikos valdymo procesu ir produktụ kūrimo bei vystymo procesụ (pvz. kuriant ,žalius" ar kitus panašia tema banko produktus ar projeltus);

= 3 LYGIS - bankas sistemingai integruoja ESG kniterijus ị rizikos valdymos procesus ir produktu kürimo bei vystymo procesus (pvz. sudarant aukšciausio rizikos seltoriaus politiką arba sudarant ịvairius sprendimụ priemimo procesus)

= 4 LYGIS - bankas pilnai integruoja ESG kriterijus ị kasdienę banko veiklą - procesus (rizikos valdyma, produktụ hürimą ir vystyma, klientụ / produltu patvirtinimo procesa), tačiau banko veiklos procesai dar nẻra perprojektuojami bei dar nèra kuriami nauji

$=5$ LYGIS - aukštas ESG kriterijụ integracijos lygis organizacijoje - atitinkamai perprojektuojami
banko veiklos procesai bei kuriami nauji verslo modeliai
}

2.5 pav. Bankų veiklos procesai (šaltinis: autorè)

Fig. 2.5. Banks' processes (source: author)

Analizuojant pastaruosius du klausimus (banko strategiją ir veiklos procesus), matyti, jog respondentuc atsakymai gerokai skiriasi- atsakymai dominuoja pradedant nuo antro lygio iki ketvirto brandumo lygio. Gali būti, kad šị skirtumą sąlygoja nevienodas bankų pažangumas socialinès atsakomybès srityje - didžiausi šalies bankai, lyginant su mažesniaisiais, iš tiesų daugiau 
kalba apie socialinę atsakomybę, yra atviresni visuomenei, prisideda prie visuomeninių projektų ir kuria savo projektus.

Panašu, kad socialinè atskaitomybe yra itin svarbi visiems apklausoje dalyvavusiems bankams - daugiau nei pusė respondentų (55\%) patvirtino, kad ji yra ịtraukta i visus pagrindinius banko pranešimus ir ataskaitas, ne mažiau $(45 \%)$ respondentų teigia, jog socialinè atskaitomybė yra įtraukta ị pagrindinę banko metinę ataskaitą (2.6 pav.).
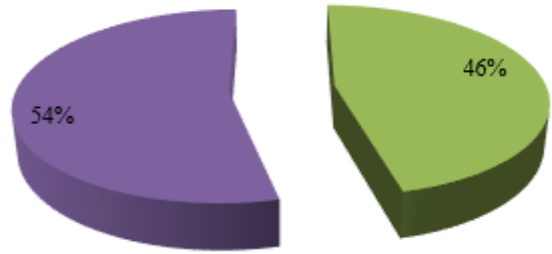

\footnotetext{
1 LYGIS - viešos socialinès atsakomybès ataskaitos nèra oficialios - daugiau pasakojamojo pobūdžio ir nẻra išsamios - pateikiama informacija tik tam tikrais klausimais (temomis);

$=3$ LYGIS - socialinés atsakomybés ataskaitos - labiau detalios ir apima platesnị spektrą problemụ bei tikslụ

= 4 LYGIS - socialinés atsakomybẻs ataskaita ịtraukta ị pagrindinẹ metinẹ atskaitomybẹ, kuri pateikiama suinteresuctoms šalims

- 5 LYGIS - socialinés atsakomybẻs ataskaitos yra integuotos ị visus pagrindinius banko pranešimus ar ataskaitas
}

2.6 pav. Bankų socialinès atskaitomybès lygis (šaltinis: autorès)

Fig. 2.6. Banks' social accountability level (source: author)

Kadangi ekspertu atsakymai i ịvairius klausimus skiriasi, ir vien pagal grafinius duomenis sudètinga identifikuoti apibendrintą bankų brandumo lygị socialinès atsakomybès srityje, papildomai pateikiami suminiai ekspertinès apklausos duomenys (2.1 lentelè).

2.1 lentelė. Bankų brandumo lygiai socialinès atsakomybės srityje (šaltinis: autorè)

Table 2.1. Banks maturity level in the field of CSR (source: author)

\begin{tabular}{cc}
\hline Brandumo lygiai & $\begin{array}{c}\text { Pasirinkimų skaičius } \\
\text { (pagal skirtingus klausimus) }\end{array}$ \\
\hline 1 brandumo lygis & 1 \\
\hline 2 brandumo lygis & 13 \\
\hline 3 brandumo lygis & 14 \\
\hline 4 brandumo lygis & 20 \\
\hline 5 brandumo lygis & 17 \\
\hline
\end{tabular}


Suminiai tyrimo rezultatai parodè, jog Lietuvoje veikiančių bankų brandumo lygis socialinès atsakomybès srityje yra tikrai aukštas - jis atitinka ketvirtą brandumo lygị. Tai reiškia, kad socialinès atsakomybès klausimai, aspektai ir kriterijai yra realiai integruojami kasdieneje banko veikloje. Grafiniai duomenys parodė ir papildomą tendenciją - nors bankų sąmoningumo lygis ir požiūris ị socialinę atsakomybę yra labai išvystyti ir tikrai aukšto lygio, vis dèlto praktikoje dar yra nemažai tobulintinų vietų (sričių). Taip pat aukštas bankų brandumo lygis socialinès atsakomybès srityje leidžia daryti prielaidą, kad atitinkamai yra ir didelis poreikis vertinti įmonių socialinę atsakomybę jas finansuojant.

\subsection{Imonių socialinès atsakomybès vertinimo kriterijų sąrankos sudarymas}

İmonių socialinės atsakomybès vertinimas visada buvo vienas didžiausių iššūkių mokslininkams, tyrëjams ir praktikams. Mokslinès literatūros (Šimanskienè ir Paužuolienè 2010, Fongwa 2010, Jurkaitis et al. 2011) analizè parodé, jog i̇monių socialiné atsakomybé gali būti vertinama labai ịvairiai: analizuojant i̇monių socialinès atsakomybès suteikiamą naudą bendrai arba pagal atskiras interesų grupes, pagal organizacinius lygmenis ar taikymo sritis. Neretai ịvairius İSA vertinimo būdus sieja vienas bendras bruožas - įmonių socialinè atsakomybė vertinama remiantis kokybinio pobūdžio kriterijais ir dažniausiai jie sudaro tris pagrindines grupes:

- aplinkosauginiai kriterijai;

- socialiniai kriterijai;

- valdymo arba ekonominiai kriterijai.

Trijų ramsčių teorija ịtraukia ekonominius kriterijus, kurių turinys yra pats svarbiausias bendrai visiems komercinių bankų finansavimo procesams. Ši teorija sąlygojo kitų pasaulinių iniciatyvų, tokių kaip GRI (Global Reporting Initiative) ar Dowo Joneso tvarumo indekso atsiradimą, todèl teorija laikytina patikimu ir tinkamu pagrindu sudarant İSA kompleksinio vertinimo sistemą.

Trijų ramsčių teorija leidžia individualiai parinkti kriterijus pagal projekto mastą ir specifiką, atsižvelgiant ị kelis apribojimus:

1 apribojimas: kokios yra šio tyrimo interesų šalys ir kas yra svarbu suinteresuotoms šalims;

2 apribojimas: eksperto, atliekančio tyrimą, tikslai;

3 apribojimas: galimybès surinkti reikalingus duomenis tyrimui (duomenu prieinamumas) (Slaper, Hall 2011).

Juozaitienė (2007) rekomenduoja sudarant vertinimo sistemą naudoti kuo paprastesnius rodiklius ir maksimaliai sumažinti jų skaičių- taip sukurta 
vertinimo sistema bus geriausiai suprantama ir neapkrauta pertekline ar apskritai nereikalinga informacija. Remiantis šiuo požiūriu, ISSA kriterijų sąranka sudaroma taip, kad suinteresuotos šalys koncentruotų dėmesį tik į esminius klausimus. Labiausiai orientuotasi i imonių finansinius rodiklius (veiklos rodiklius), darant prielaidą, kad jie finansuotojams yra svarbiausi. Atitinkamai šią ekonominę grupę siūloma ịvardyti kaip finansinę. Formuojant teorinị pagrindą ekonominę-finansinę rodiklių grupę sudaro Juozaitienès (2007), Antanavičienès ir Šimelytès (2014) bei Elena (2012) siūlomi finansuotojams, kaip suinteresuotai šaliai, aktualūs finansiniai rodikliai. Pelningumo rodiklių grupę siūloma papildyti keliais svarbiais finansiniais rodikliais, kuriuos numato mokslininkai ir tyrejjai Monea (2009), Kneževic et al. (2011), Kotane, KuzminaMerlino (2012) ir kt. Detalizuoti finansiniai rodikliai ir jų apskaičiavimo formulès pateikiamos D priede (remiantis Lan 2012, Babalola, Abiola 2013, Financial Ratio Analysis 2016), o detalus visų ISA kriterijų grupių teorinis pagrindas pateikiamas 2.2 lentelëje.

2.2 lentelè. İmonių socialinės atsakomybės kriterijų sąrankos teorinio pagrindo formavimas (šaltinis: autorè)

Table 2.2. Theoretical background formation corporate social responsibility criteria setup (source: author)

\begin{tabular}{|c|c|}
\hline Kriterijų grupè & Teorinis pagrindas \\
\hline \multirow{3}{*}{$\begin{array}{l}\text { Ekonominiai - } \\
\text { finansiniai }\end{array}$} & $\begin{array}{l}\text { Finansinių rodiklių bazè (Juozaitienè 2007, Antanavičienè, } \\
\text { Šimelytė 2014, Elena 2012); }\end{array}$ \\
\hline & $\begin{array}{l}\text { Pelningumo rodiklių papildymas (Monea (2009), Kneževic et al. } \\
\text { (2011), Kotane, Kuzmina-Merlino (2012), Krivka, Stonkutè } \\
\text { (2015), Wang, Lee (2010), Šapalienè et al. (2014) bei Daujotaite } \\
\text { (2006); }\end{array}$ \\
\hline & TBL teorija (Elkington 1997, Goel 2010, Slaper, Hall 2011). \\
\hline \multirow[b]{2}{*}{ Aplinkosauginiai } & TBL teorija (Elkington 1997, Goel 2010, Slaper, Hall 2011); \\
\hline & $\begin{array}{l}\text { REPORT 2014: Environmental, Social and Governance: } \\
\text { Integration for Banks: a Guide to Starting Implementation. }\end{array}$ \\
\hline \multirow[b]{2}{*}{ Socialiniai } & TBL teorija (Elkington 1997, Goel 2010, Slaper, Hall 2011); \\
\hline & $\begin{array}{l}\text { REPORT 2014: Environmental, Social and Governance: } \\
\text { Integration for Banks: a Guide to Starting Implementation. }\end{array}$ \\
\hline Valdymo & $\begin{array}{l}\text { REPORT 2014: Environmental, Social and Governance: } \\
\text { Integration for Banks: a Guide to Starting Implementation. }\end{array}$ \\
\hline
\end{tabular}


Taigi, ISSA kompleksinio vertinimo sistemai sudaryti siūloma taikyti keturias kriterijų grupes: ekonominių - finansinių, aplinkosauginių, socialinių bei valdymo.

Atlikus mokslinès literatūros analizę bei suformavus teorinị pagrindą, identifikuojami įmonių socialinès atsakomybès vertinimui galimai aktualūs kriterijai (2.3. lentelè).

2.3 lentelè. İmonių socialinės atsakomybès kriterijų sąrankos formavimas (šaltinis: autorè)

Table 2.3. Formation of corporate social responsibility criteria setup (source: author)

\begin{tabular}{|c|c|c|}
\hline Kriterijų grupė & Eil. Nr. & Kriterijai \\
\hline \multirow{14}{*}{$\begin{array}{l}\text { Ekonominiai - } \\
\text { finansiniai }\end{array}$} & 1. & Bendrasis pelningumas \\
\hline & 2. & Grynasis pelningumas \\
\hline & 3. & Veiklos pelningumas \\
\hline & 4. & EBITDA marža \\
\hline & 5. & ROA \\
\hline & 6. & ROE \\
\hline & 7. & ROI \\
\hline & 8. & Bendrojo likvidumo koeficientas \\
\hline & 9. & Greitojo likvidumo koeficientas \\
\hline & 10. & Likvidacinè vertè \\
\hline & 11. & Skolų ir turto santykis \\
\hline & 12. & Skolų ir nuosavo kapitalo santykis \\
\hline & 13. & Skolų ir EBITDA santykis \\
\hline & 14. & Palūkanų padengimo koeficientas \\
\hline \multirow{7}{*}{ Aplinkosauginiai } & 15. & Tarša ir jos mažinimas \\
\hline & 16. & $\begin{array}{l}\text { Poveikis vandens kokybei, vandens kiekio } \\
\text { suvartojimas ir pan. }\end{array}$ \\
\hline & 17. & Oro tarša \\
\hline & 18. & $\begin{array}{l}\text { Kietujų, kenksmingų ir pavojingų medžiagų bei } \\
\text { kitokių atliekų išmetimas }\end{array}$ \\
\hline & 19. & $\begin{array}{l}\text { Poveikis aplinkai, atsiradęs dèl žemės paskirties } \\
\text { keitimo }\end{array}$ \\
\hline & 20. & Išteklių naudojimo efektyvumas \\
\hline & 21. & İsipareigojimas spręsti įvairių ekosistemų klausimus \\
\hline
\end{tabular}




\section{3 lentelès pabaiga}

\begin{tabular}{|c|c|c|}
\hline Kriterijų grupè & Eil. Nr. & Kriterijai \\
\hline \multirow{5}{*}{ Socialiniai } & 22. & $\begin{array}{l}\text { Darbuotojų teisès / atitiktis darbo standartams / } \\
\text { laikymasis sveikatos ir saugos normų }\end{array}$ \\
\hline & 23. & Darbuotojų sveikata ir sauga \\
\hline & 24. & $\begin{array}{l}\text { Darbuotojų konsultacijos, parengimas ir susitarimai } \\
\text { dėl kiekvieno fizinio ar ekonominio pasikeitimo, } \\
\text { ịvykusio dèl įmonès veiklos }\end{array}$ \\
\hline & 25. & $\begin{array}{l}\text { Poveikis bendruomenėms, tautinėms mažumoms, } \\
\text { moterims ir kitoms labiau pažeidžiamoms grupėms }\end{array}$ \\
\hline & 26. & Poveikis kultūriniam ir religiniam paveldui \\
\hline \multirow{3}{*}{ Valdymo } & 27. & Korupcija ir kyšininkavimas \\
\hline & 28. & Reputacija \\
\hline & 29. & İmonès valdymo efektyvumas \\
\hline
\end{tabular}

Numatyta, jog šiame darbe siūloma vertinimo sistema skirsis nuo naujausioje mokslinèje literatūroje aprašytų vertinimo sistemų (Nieto, Cinca 2016) tokiais aspektais:

- siūloma İSA kompleksinè vertinimo sistema bus unikali savo moksliniu ir praktiniu naujumu, o ne atitiktis finansuotojų naudojamai įmonés veiklos vertinimo sistemai (angl. credit score system);

- kiekybiniai kriterijai, t. y. ekonominiai-finansiniai, turètų būti vertinami tik tiek, kiek jie turi įtakos bendrai vertinant įmonių socialinę atsakomybę. Detaliau ekonominiai-finansiniai rodikliai turètų būti analizuojami ir vertinami atskiroje įmonès veiklos vertinimo ataskaitoje.

Siūloma İSA vertinimo sistema daugiausia būtų skirta komerciniams bankams, tačiau galètų būti taikoma ir specifinių bankų, pvz., tų, kurie orientuoti tik $\mathfrak{i}$,žalių“ paskolų suteikimą arba kitų finansinių institucijų, kurios veikia kaip socialinè misija (angl. ethical banks, financial entities with a social mission, revolving loan and savings funds structures, social entities that do not collect savings - pagal Nieto, Cinca 2016). 


\subsection{Imonių socialinès atsakomybès kompleksinio vertinimo sistemos teorinis modeliavimas pasitelkiant daugiakriterinio vertinimo metodus}

\subsubsection{Sistemą sudarančių kriterijų reikšmingumų nustatymas taikant AHP metodą}

Norint sudaryti İSA vertinimo sistemą, leidžiančią tinkamai įvertinti ịmonių socialinę atsakomybę, visų pirma būtina nustatyti vertinimo sistemą sudarančių kriterijų reikšmingumus. Juos nustačius galima ịvertinti kiekvieną kriterijaus „svorį“ kito kriterijaus atžvilgiu bei nustatyti, kiek tas kriterijus svarbus bendroje ISA vertinimo sistemoje. Be to, ị nagrinèjamą ISA vertinimo sistemą ịtrauktų kriterijų agregavimas leis viena reikšme identifikuoti socialinès atsakomybės lygi įmonèje. Apskaičiuojant bendrą indeksą taip pat būtina ịvertinti kiekvieno kriterijaus svarbą (Tvaronavičienè et al. 2008).

Mokslinėje ir praktinejje literatūroje İSA kriterijų svorių analizių paskelbta nedaug. Viena iš galimų priežasčių - veikia nemažai tarptautinių ir lokalių organizacijų, kurios pateikia gana skirtingas ĮSA kriterijų sąrankas. Kaip jau buvo analizuota teorinejje darbo dalyje, kriterijų sąrankos priklauso nuo organizacijos veiklos pobūdžio, tikslinės auditorijos - kas naudos tą kriterijų sąranką arba ką siekiama igyvendinti šiais kriterijais (pvz., pateikti socialinès atsakomybės ataskaitų rengimo gaires). Kita priežastis - İSA kriterijus, kaip kokybinius parametrus, yra sunku ịvertinti ar kaip nors standartizuoti taikant konkrečias formules. Tačiau naujausioje mokslinèje literatūroje jau diskutuojama ir ieškoma būdų, kaip reikètų ìvertinti ịmonių socialinę atsakomybę (Searcy 2012), o kai kurie mokslininkai bando taikyti ir konkrečius metodus - pavyzdžiui, GutierrezNieto et al. (2016) išskyrè 26 kriterijus, kurie visi bendrai sudaro kredito rizikos vertinimo sistemą (angl. credit score system), ir nustate kiekvieno iš jų reikšmingumą taikydamas T. L. Saaty pasiūlytą matematini Analitinès hierarchijos analizès metodą (angl. Analitic Hierarchy Process method arba AHP). Šis daugiakriterinio vertinimo metodas populiarus ir tarp Lietuvos mokslininku (Ginevičius, Podvezko 2008b, Ginevičius et al. 2004a, Rakauskienè, Tamošiūnienè 2013, Zavadskas, Turskis 2011, Tvaronavičienè et al. 2008), jis plačiai taikomas mikro- ir makroekonomikos srityse. Nors AHP metodas labai dažnai taikomas vertinant kiekybinius pradinius rodiklius, tačiau pagrindžiant šio metodo taikymą dažnai remiamasi kokybiniais pradiniais rodikliais (Zavadskas, Turskis 2011, Saaty 1994). Todèl AHP itin populiarus sprendžiant ịvairaus pobūdžio etines, socialines ir panašias problemas (Millet 1998, Ruf et al.1998, Stein, Ahmad 2008). 
Atsižvelgiant $\mathfrak{i}$ tai, kad šiame tyrime didžioji dalis I̦SA kriterijų yra sunkiai nustatomi - t. y. kokybinio pobūdžio, ekspertinis vertinimas bus taikomas kaip tinkamiausias pagrindas nustatant kriterijų reikšmingumą (Ginevičius 2006). Be jau anksčiau išvardytų priežasčių, AHP metodas taip pat tinka, nes:

- ISA kriterijų sąranką sudaro sąlyginai nemažai kriterijų - iš viso 29, todèl tokiu atveju tiesioginis vertinimas, kai vieneto dalimis galima nurodyti reikšmingumus, nėra pats tinkamiausias (Ginevičius 2006);

- siūlomas metodas leis nustatyti kriterijų reikšmingumus ne tik vienas kito atžvilgiu, bet ir nustatyto tikslo - İSA vertinimo sistemos atžvilgiu;

- šio metodo esmé yra ta, kad atliekant ekspertini vertinimą reikia palyginti vieną veiksnị kito ažvilgiu, nurodant, ar pirmasis veiksnys yra svarbesnis, ar mažiau svarbus už antrajį. Lyginant gautas rezultatas sudaro hierarchinę arba tinklo struktūrą, kurioje visi kriterijai yra tarpusavyje susiję ir ịvertinti vienas su kitu sprendžiamos problemos ar klausimo atžvilgiu (Saaty, Sagir 2009). Matematiškai šis darinys išreiškiamas kvadratine matrica, kai $P=\left[p_{i j}\right], i, j=1,2, \ldots$, o $n$ - veiksnių skaičius, $w_{i}-i$-tojo veiksnio svoris. Matrica iggauna tokị pavidalą:

$$
P=\left[\begin{array}{cccc}
p_{11} & p_{12} & \cdots & p_{1 n} \\
p_{21} & p_{22} & \cdots & p_{2 n} \\
\vdots & \vdots & \cdots & \vdots \\
p_{n 1} & p_{n 2} & \cdots & p_{n n}
\end{array}\right]=\left[\begin{array}{cccc}
\frac{w_{1}}{w_{1}} & \frac{w_{1}}{w_{2}} & \cdots & \frac{w_{1}}{w_{n}} \\
\frac{w_{2}}{w_{1}} & \frac{w_{2}}{w_{2}} & \cdots & \frac{w_{2}}{w_{n}} \\
\vdots & \vdots & \cdots & \vdots \\
\frac{w_{n}}{w_{1}} & \frac{w_{n}}{w_{2}} & \cdots & \frac{w_{n}}{w_{n}}
\end{array}\right] .
$$

Svarbu tai, kad bendra visų veiksnių ar kriterijų reikšmingumų suma turi būti lygi vienetui:

$$
\sum_{j=1}^{n} w_{j}=1
$$

O nežinomos $w_{1}, w_{2}, \ldots, w_{n}$ reikšmès randamos pagal Saaty pasiūlytą veiksnių vertinimo skalę (2.4 lentelè).

Iš viso matricoje reikia atlikti $n(n-1) / 2$ porinių lyginimų (kai $n$-lyginamų veiksnių skaičius).

Tačiau šioje vietoje susiduriama su problema, kad kai yra daugiau nei 12 veiksnių ar kriterijų, manoma, jog ekspertas, suteikdamas reikšmę vienam veiksniui kito atžvilgiu, tuo pačiu negali teisingai nustatyti ịtakos santykių tarp visų poros veiksnių - pavyzdžiui, jeigu pirmasis veiksnys yra svarbesnis negu antras, o antras svarbesnis nei trečias, tada pirmas veiksnys bus visada svarbesnis negu trečias veiksnys. Atitinkamai šios aplinkybès gali sąlygoti 
netinkamą matricos užpildymą. Tačiau šią problemą sprendžia matricos suderinamumo užtikrinimas, skaičiuojant konkordancijos koeficientą (Ginevičius 2006, Podvezko 2009).

2.4 lentelè. Saaty veiksnių vertinimo skalè (šaltinis: Saaty 1994, 2001, 2008)

Table 2.4. Factors` assessment scale by Saaty (source: Saaty 1994, 2001, 2008)

\begin{tabular}{|c|c|c|}
\hline $\begin{array}{c}\text { Veiksnio } \\
\text { vertinimas }\end{array}$ & Reikšmė & Paaiškinimas \\
\hline 1 & $\begin{array}{l}\text { Vienodas } \\
\text { svarbumas }\end{array}$ & Abiejų veiksnių įtaka siekiant tikslo yra vienoda \\
\hline 3 & $\begin{array}{l}\text { Vidutinis } \\
\text { svarbumas }\end{array}$ & $\begin{array}{l}\text { Pirmo veiksnio įtaka siekiant tikslo, lyginant su } \\
\text { antru veiksniu, yra labai nežymiai didesné }\end{array}$ \\
\hline 5 & Svarbus & $\begin{array}{l}\text { Pirmo veiksnio ịtaka siekiant tikslo, lyginant su } \\
\text { antru veiksniu, yra vidutiniškai didesne }\end{array}$ \\
\hline 7 & $\begin{array}{l}\text { Labai svarbus } \\
\text { arba svarbumas } \\
\text { irodytas }\end{array}$ & $\begin{array}{l}\text { Pirmo veiksnio ịtaka siekiant tikslo, lyginant su } \\
\text { antru veiksniu, yra daug didesne arba vieno } \\
\text { veiksnio dominavimas kito veiksnio atžvilgiu yra } \\
\text { praktiškai įrodytas }\end{array}$ \\
\hline 5 & Ypač svarbus & $\begin{array}{l}\text { Pirmo veiksnio įtaka siekiant tikslo, lyginant su } \\
\text { antru veiksniu, yra didžiausia, kokia gali būti. }\end{array}$ \\
\hline $2,4,6,8$ & & $\begin{array}{l}\text { Naudojamos kaip tarpinės reikšmės (kompromiso } \\
\text { atveju) }\end{array}$ \\
\hline $1 / 1,1 / 2, \ldots, 1 / 9$ & $\begin{array}{l}\text { Koks atvirkštinis } \\
\text { dydis taikomas, } \\
\text { priklauso nuo to, } \\
\text { kaip veiksniai } \\
\text { vertinami vienas } \\
\text { kito atžvilgiu }\end{array}$ & $\begin{array}{l}\text { Remiantis logika, jog pirmo veiksnio įtaka } \\
\text { siekiant tikslo, lyginant su antru veiksniu, yra } \\
\text { mažesne }\end{array}$ \\
\hline
\end{tabular}

Sąlyga, kuri reikalinga tam, kad matrica būtų suderinta, taip pat gali būti išreikšta matematiškai. Idealiu atveju, kai bendra visų veiksnių ar kriterijų reikšmingumų suma lygi vienetui, matrica $P$ turi būti padauginta iš veiksnių reikšmingumų stulpelio, t. y. iš transponuotos eilutès $w=\left(w_{1}, w_{2}, \ldots, w_{n}\right)^{T}$ :

$$
P w=\left[\begin{array}{ccc}
\frac{w_{1}}{w_{1}} \frac{w_{1}}{w_{2}} & \cdots & \frac{w_{1}}{w_{n}} \\
\vdots & \cdots & \vdots \\
\frac{w_{n}}{w_{1}} \frac{w_{1}}{w_{2}} & \cdots & \frac{w_{n}}{w_{n}}
\end{array}\right]\left[\begin{array}{c}
w_{1} \\
w_{2} \\
\vdots \\
w_{n}
\end{array}\right]=\left[\begin{array}{c}
n w_{1} \\
n w_{2} \\
\vdots \\
n w_{n}
\end{array}\right]=n\left[\begin{array}{c}
w_{1} \\
w_{2} \\
\vdots \\
w_{n}
\end{array}\right]=n w .
$$


Iš veiksnių reikšmingumų gautas vektorius $w$ yra tikrinio vektoriaus komponentai, kurie yra normalizuoti atsižvelgiant ị didžiausią matricos $P$ tikrinę reikšmę $\lambda_{\max }$, t. y.:

$$
P w=\lambda_{\max } w .
$$

Didžiausia atvirkščiai simetriškos matricos $n$ eilutės tikrinè reikšmė yra $\lambda_{\max } \geq n$. Kai matrica yra visiškai suderinta ir stulpelių elementai yra proporcingi, tada $\lambda_{\max }=n$, jeigu taip nèra, tada matricos suderinamumas apibūdinamas skirtumu $\lambda_{\max -} n$ (Podvezko 2009; Rakauskienè 2013). Toliau skaičiuojamas ekspertų vertinimo suderinamumo indeksas:

$$
S_{I}=\frac{\lambda_{\max }-n}{n-1} .
$$

Kuo mažesnis suderinamumo indeksas, tuo matrica laikoma labiau suderinta. Idealiu atveju $S_{I}=0$. Tačiau praktika rodo, jog toks matricos suderinamumo indeksas yra gana retas atvejis. Suderinamumo laipsnis $S_{S}$ apskaičiuojamas padalinus suderinamumo indeksą $S_{I}$ iš skaičiaus, atitinkančio tos pačios eilès matricos atsitiktinius suderinamumus $S_{A}$ :

$$
S_{S}=\frac{S_{I}}{S_{A}}
$$

Atsitiktiniai suderinamumai $S_{A}$ randami 2.5 lentelèje (Podvezko 2009, Rakauskienè 2013).

2.5 lentelè. Atsitiktinių suderinamumų indeksų reikšmės (šaltinis: Saaty 2008; Podvezko 2009)

Table 2.5. Means of random compatibility index (source Saaty 2008; Podvezko 2009)

\begin{tabular}{lcccccccc}
\hline $\begin{array}{l}\text { Matricos } \\
\text { dydis }\end{array}$ & 1 & 2 & 3 & 4 & 5 & 6 & 7 & 8 \\
\hline$S_{A}$ & 0 & 0 & 0,58 & 0,90 & 1,12 & 1,24 & 1,32 & 1,41 \\
\hline $\begin{array}{l}\text { Matricos } \\
\text { dydis }\end{array}$ & 9 & 10 & 11 & 12 & 13 & 14 & 15 & \\
\cline { 1 - 5 }$S_{A}$ & 1,45 & 1,49 & 1,51 & 1,48 & 1,56 & 1,57 & 1,59 & \\
\cline { 1 - 5 }
\end{tabular}


Jeigu suderinamumo laipsnis $S_{S} \leq 0,1$, laikoma, kad matrica yra suderinta. Neatitinkant šios sąlygos, ekspertai turi dar kartą atidžiai peržiūrèti ir ịvertinti matricos elementus (Podvezko 2009).

Tokiais atvejais, kai matricos dydis yra $n>15$, vidutinès atsitiktinių suderinamumų $S_{A}$ reikšmès apskaičiuojamos pagal tokią formulę:

$$
S_{A}=\frac{1,98(n-2)}{n} .
$$

Taikant šią formulę, gaunamos $S_{A}$ reikšmès yra šiek tiek didesnès nei atsitiktinių suderinamumų indeksų reikšmès iš lentelès, pavyzdžiui, jeigu matricos dydis 15 , tai indeksas pagal šią formulę yra $S_{A}=1,72$, kai pagal lentelę $S_{A}=1,59$ (Podvezko 2009).

Bendras ekspertu nuomonių sutapimo lygis, arba kitaip vadinamas konkordancijos koeficientas $W$, nustatomas ranguojant veiksnius arba kriterijus pagal svarbumą, t. y. svarbiausiam veiksniui priskiriant aukščiausią reikšmę, kuri yra lygi vienetui, mažesniam pagal ịtaką veiksniui priskiriama kita reikšmè - 2, ir t. t. Vienodiems vertinimams priskiriamas tas pats rangas eilinių rangų aritmetinis vidurkis (Podvezko 2006). Konkordancijos koeficientą galima apskaičiuoti pagal formulę:

$$
W=\frac{12 S_{k s}}{r^{2} n\left(n^{2}-1\right)},
$$

čia $r$ - ekspertų skaičius, $n$ - vertinamų veiksnių skaičius, $S_{k s}$ - veiksnių rangų sumų nuokrypių nuo bendro vidurkio kvadratų suma, kuri apskaičiuojama pagal šią formulę:

$$
S_{k s}=\sum_{j=1}^{n}\left(r \times j-\frac{1}{2} r(n+1)\right)^{2} .
$$

Kai ekspertų vertinimai prieštaringi, konkordancijos koeficientas artejja link $0(W \rightarrow 0)$, o kai ekspertų nuomonė vieninga - konkordancijos koeficientas artèja link $1(W \rightarrow 1)$ (Baležentis, Žalimaitė 2011). Anot Pridotkienès ir Pridotko (2012), ekspertų nuomoné laikoma pakankamai vieninga, kai konkordancijos koeficientas siekia (arba viršija) 0,6 reikšmę. Tada ekspertinis vertinimas laikomas patikimu ir baigtu.

Jeigu veiksnių ar kriterijų skaičius yra daugiau nei septyni $(n>7)$, konkordancijos koeficiento reikšmingumas gali būti nustatytas naudojant $\chi^{2}$ kriterijų (Podvezko 2005): 


$$
\chi^{2}=W r(n-1) \frac{12 S_{k s}}{r n(n+1)} .
$$

Jeigu gauta $\chi^{2}$ reikšmè yra didesnè už kritinę $\chi_{k r}{ }^{2}$ iš $\chi^{2}$ skirstinio lentelès su $v=n-1$ laisvès laipsniu ir pasirinktu reikšmingumo lygmeniu $\alpha$, artimu nuliui, vadinasi, ekspertų vertinimai yra suderinti ir veiksnių reikšmingumus galima taikyti tolesniems skaičiavimams (Podvezko 2005, Rakauskienė 2013).

Kai lyginamų veiksnių skaičius $n$ yra nuo 3 iki $7, \chi^{2}$ skirstinị reikia taikyti atsargiai, nes kritinė $\chi_{k r}{ }^{2}$ reikšmè gali būti didesnè už suskaičiuotą, nors ekspertų nuomonių suderinamumo lygis yra gana aukštas. Tokiu atveju siūloma taikyti konkordancijos koeficiento tikimybines lenteles arba kritinių reikšmių $S$ lenteles.

Konkordancijos koeficiento ir suderinamumo nustatymo metodų taikymas parodo, kad nors vertinimų rezultatai ir svyruoja, ekspertų nuomonès vis tiek gali būti statistiškai suderintos. Jeigu gauta $\chi^{2}$ reikšmė mažai skiriasi nuo kritinès $\chi_{k r}{ }^{2}$ reikšmès, tai parodo, jog atsitiktinumo įtaka gali pakeisti suderinamumą, o vertinimo rezultatai tokiu atveju parodo mažą patikimumo lygi (Podvezko 2006).

\subsubsection{Kitụ daugiakriterinio vertinimo metodụ integravimas ir jụ suderinamumo nustatymas}

Šiandien daugelis mokslininkų vieningai sutaria, jog ịmonès finansinè būklè ir veikla negali būti vertinama pagal vieną finansinị rodiklị ar pagal tam tikrą grupę rodiklių. Priešingai, ịmonès veikla turi būti vertinama iš ịvairių perspektyvų - pagal ịvairius rodiklius ir jų grupes. Dar daugiau - visi rodikliai gali netgi prieštarauti vieni kitiems, skirtis savo matavimo vienetais. Tokiu atveju kyla poreikis visus tuos rodiklius apjungti ir surasti bendrą kriterijų ar indeksą, kuris leistų spręsti apie įmonès finansinę būklę, socialinès atsakomybės lygi ar kitus veiklos rezultatus. Šiam tikslui plačiausiai taikomi ịvairūs daugiakriteriniai vertinimo metodai, apimantys ịvairias sritis - nuo statybu sektoriaus (Kalibatas et al. 2012, Šaparauskas et al. 2011, Zavadskas et al. 2008, Keskin 2013, Turskis 2008), energetikos (Zolfani, Saparauskas 2013, Erguden ir Catlioglu 2016) iki vadybos ir ekonomikos (Ginevičius et al. 2012, 2013, Ginevičius, Podvezko 2008a, Ginevičius, Podviezko 2011, 2013, Hsu 2013).

Nors daugiakriteriniai vertinimo metodai dažniausiai taikomi vertinant kiekybinio pobūdžio rodiklius, naujausiuose moksliniuose tyrimuose jau ieškoma būdų, kaip socialinius aspektus integruoti ị finansavimo procesus. Gutierrez-Nieto ir Serrano-Cinca (2016) pasiūlè sprendimų prièmimo modelị finansuotojams, kuris apima socialinius ir finansinius aspektus. Mokslininkai kiekvieną aspektą sieja su tuo, i ką yra orientuotas finansuotojas, pvz., kai kurie labiau labiau teikia pirmenybę aplinkosauginiams aspektams, kiti - teisių 
suteikimui moterims. Sudarant modeli (kreditavimo proceso sprendimų prièmimui) naudojamas daugiakriterinis vertinimas. Mokslininkai savo darbe taiko populiariausius daugiakriterinio vertinimo metodus: MAUT (MultipleAttribute Utility Theory), MAVT (Multiple-Attribute Value Theory) ir AHP. Sukurtą modelị iš viso sudaro 26 kriterijai, iš kurių 3 kriterijai apima ịmonès veiklos istoriją, 14 kriterijų - esamą situaciją (finansinius rodiklius ir nematerialujj turtą) ir 9 - prašomos paskolos kriterijus (finansinius ir socialinius). Modelis daugiausia orientuotas ị specifinius finansuotojus - etiškus bankus, kurie teikia tik „žalias“ paskolas, bei kitas finansines institucijas, veikiančias kaip socialinè misija.

Gutierrez-Nieto ir Serrano-Cinca (2016) siūlomas vertinimo modelis yra ribotas dèl savo orientacijos tik ị socialinių projektų vertinimą ir finansavimą (angl. green loans), o šiame disertaciniame darbe siūlomą vertinimo sistemą būtų galima taikyti visoms ịmonèms ir visiems jų galimiems projektams, nepriklausomai nuo to, ar projektas orientuotas ị socialinę atsakomybę. Taigi ši vertinimo sistema būtų kur kas universalesnè.

Vienas labiausiai diskutuotinų teorinių ir praktinių klausimų - kaip atsirinkti tinkamiausius daugiakriterinio vertinimo metodus, kuriuos būtų galima sujungti i bendrą sistemą sprendžiant konkretu klausimą. Taikant ịvairius metodus, pastebèta, kad dèl savo specifikos (pranašumų ir trūkumų, vidinès logikos) skaičiavimo rezultatai, taikant šiuos metodus, skiriasi. Todèl siekiant sumažinti daugiakriterinio vertinimo metodų specifikos ịtaką galutiniams rezultatams, šiame darbe siūloma sudarant ISA vertinimo sistemą naudoti kelis daugiakriterinio vertinimo metodus (Ginevičius, Podvezko 2008a).

Zavadskis, Turskis (2011) pateikia aktualią šiam disertaciniam darbui metodų klasifikaciją, pagal kurią jie skirstomi ị grupes, atsižvelgiant ị turimos informacijos tipą:

- metodai, pagristi kiekybiniais vertinimais: TOPSIS, LINMAP, MOORA, COPRAS, COPRAS-G;

- metodai, pagrịsti kokybiniais pradiniais vertinimais: AHP ir fuzzy set theory metodai (Zimmermann 2000);

- lyginamieji pirmumo metodai (angl. Comparative preference methods), pagrịsti poriniu alternatyvų lyginimu. $\breve{S}$ i metodų grupé apima tokius metodus kaip ELECTRE, PROMETHEE, TACTIC, ORESTE ir kitus daugiakriterinius metodus (Turskis 2008);

- metodai, pagrịsti kokybiniais vertinimais. Jie netransformuojami i kiekybinius kintamuosius, apima žodinę sprendimų prièmimo analizę, priimant sprendimus naudojami kokybiniai duomenys. Šiems metodams būdingas aukšto lygio neapibrěžtumas;

- taip pat pagal alternatyvų sriț daugiakriteriniai vertinimo metodai gali būti skirstomi ị nepertraukiamus arba diskrečiuosius; 
- atsižvelgiant i tai, kad visi İSA vertinimo sistemos kriterijų duomenys kokybiniai, o vėliau ekspertinio vertinimo būdu bus transformuoti $i$ kiekybinius parametrus, siūloma toliau taikyti daugiakriterinio vertinimo metodus iš šių grupių - metodai, kurie grindžiami kokybiniais pradiniais vertinimais (AHP ir fuzzy set theory metodai) bei metodai, kurie grindžiami kiekybiniais vertinimais (TOPSIS, LINMAP, ir kt.). Toliau atrenkant konkrečius daugiakriterinio vertinimo metodus, remiamasi tokia logika - metodai atrenkami pagal taikymo populiarumą (dažniausiai naudojami ir šiandien ekonomikoje aktualūs metodai), sritis, kuriose buvo naudojami, bei konkrečios problemos specifiką (kad būtų artima šiam disertaciniam darbui).

Taigi, be jau aprašyto AHP metodo, taip pat šiame darbe siūloma ịtraukti šiuos daugiakriterinio vertinimo metodus (2.6 lentelè).

2.6 lentelè. Daugiakriterinių vertinimo metodų pritaikymas sprendžiant įvairaus pobūdžio mokslines problemas (šaltinis: autorè)

Table 2.6. Application of multi criteria methods for solving various scientific problems (source: author)

\begin{tabular}{|c|c|c|}
\hline DVB & Autorius & Sprendžiama problema \\
\hline \multirow{4}{*}{$\begin{array}{l}\text { COPRAS } \\
\text { (Complex } \\
\text { Proportional } \\
\text { Assessment) }\end{array}$} & $\begin{array}{l}\text { Ginevičius, } \\
\text { Podvezko } \\
2008 b\end{array}$ & $\begin{array}{l}\text { Komercinių bankų Lietuvoje patikimumo } \\
\text { vertinimas }\end{array}$ \\
\hline & $\begin{array}{l}\text { Uzsilaityte, } \\
\text { Martinaitis } \\
2010\end{array}$ & $\begin{array}{l}\text { Ivvairių būsto renovacijos alternatyvų palyginimas, } \\
\text { įtraukiant energetinius, ekonominius ir aplinkos } \\
\text { bei aplinkosauginius kriterijus, įvertinant } \\
\text { renovacijos priemonių poveikị }\end{array}$ \\
\hline & Podvezko 2011 & $\begin{array}{l}\text { Lyginamoji analizè SAW ir COPRAS } \\
\text { daugiakriterinis vertinimo būdas }\end{array}$ \\
\hline & $\begin{array}{l}\text { Parezanovic } \\
\text { et al. } 2016\end{array}$ & $\begin{array}{l}\text { COPRAS metodas naudojamas transporto } \\
\text { sektoriuje, siekiant suranguoti } 26 \text { darnaus } \\
\text { mobilumo (judejjimo) priemones. }\end{array}$ \\
\hline \multirow{2}{*}{$\begin{array}{l}\text { TOPSIS } \\
\text { (Technique } \\
\text { for Order } \\
\text { Preference } \\
\text { by Similarity } \\
\text { to an Ideal } \\
\text { Solution) }\end{array}$} & Wu et al. 2009 & $\begin{array}{l}\text { Fuzzy AHP (FAHP) ir trys DVB analitiniai } \\
\text { metodai - SAW, TOPSIS ir VIKOR panaudoti } \\
\text { ranguojant bankus pagal efektyvumą ir šalinant } \\
\text { trijų bankų veiklos spragas bei didinant jų } \\
\text { konkurencingumą. }\end{array}$ \\
\hline & $\begin{array}{l}\text { Ginevičius, } \\
\text { Podvezko } \\
2008 b\end{array}$ & $\begin{array}{l}\text { Komercinių bankų Lietuvoje patikimumo } \\
\text { vertinimas }\end{array}$ \\
\hline
\end{tabular}


2.6 lentelès tęsinys

\begin{tabular}{|c|c|c|}
\hline DVB & Autorius & Sprendžiama problema \\
\hline & $\begin{array}{l}\text { Ginevičius, } \\
\text { Podvezko } \\
2008 \mathrm{a}\end{array}$ & $\begin{array}{l}\text { AHP, SAW, VS, GV, TOPSIS, VIKOR } \\
\text { daugiakriterinio vertinimo būdai buvo taikomi } \\
\text { vertinant nefinansinių įmonių komercinę ir ūkinę } \\
\text { veiklą bei (išskyrus AHP metodą) vertinant naujų } \\
\text { Europos Sąjungos narių konkurencingumo lygį. }\end{array}$ \\
\hline & $\begin{array}{l}\text { Erguden, } \\
\text { Catlioglu } 2016\end{array}$ & $\begin{array}{l}\text { TOPSIS metodas naudojamas vertinant ir } \\
\text { tarpusavyje lyginant įvairių Turkijoje veikiančių } \\
\text { energetikos įmonių įnašą ị darnumą. }\end{array}$ \\
\hline \multirow{5}{*}{$\begin{array}{l}\text { SAW } \\
\text { (Simple } \\
\text { Additive } \\
\text { Weighting) }\end{array}$} & $\begin{array}{l}\text { Ginevičius et al. } \\
2010\end{array}$ & $\begin{array}{l}\text { Imonès konkurencinès strategijos formavimas } \\
\text { oligopolinės rinkos sąlygomis }\end{array}$ \\
\hline & Podvezko 2011 & $\begin{array}{l}\text { Lyginamoji analizė SAW ir COPRAS } \\
\text { daugiakriterinis vertinimo būdas. }\end{array}$ \\
\hline & $\begin{array}{l}\text { Ginevičius, } \\
\text { Podvezko } \\
2008 b\end{array}$ & $\begin{array}{l}\text { Komercinių bankų Lietuvoje patikimumo } \\
\text { vertinimas. }\end{array}$ \\
\hline & $\begin{array}{l}\text { Stankovič et al. } \\
2016\end{array}$ & $\begin{array}{l}\text { Vietos ekonominès aplinkos vertinimas, } \\
\text { atliekamas remiantis trijų Serbijos savivaldybių } \\
\text { duomenimis. }\end{array}$ \\
\hline & $\begin{array}{l}\text { Žvirblis, } \\
\text { Zinkevičiūte } \\
2008\end{array}$ & $\begin{array}{l}\text { SAW metodas taikomas vertinant įmonių } \\
\text { Lietuvoje, užsiimančių krovinių gabenimu, } \\
\text { makroaplinką. }\end{array}$ \\
\hline $\begin{array}{l}\text { VS (Visų } \\
\text { rodiklių } \\
\text { vienetų } \\
\text { suma) }\end{array}$ & $\begin{array}{l}\text { Ginevičius, } \\
\text { Podvezko } \\
2008 \mathrm{a}\end{array}$ & $\begin{array}{l}\text { AHP, SAW, VS, GV, TOPSIS, VIKOR } \\
\text { daugiakriterinio vertinimo būdai buvo taikomi } \\
\text { vertinant nefinansinių įmonių komercinę ir ūkinę } \\
\text { veiklą bei (išskyrus AHP metodą) naujų Europos } \\
\text { Sąjungos narių konkurencingumą. }\end{array}$ \\
\hline \multirow{3}{*}{ VIKOR } & Wu et al. 2009 & $\begin{array}{l}\text { Fuzzy AHP (FAHP) ir trys DVB analitiniai } \\
\text { metodai - SAW, TOPSIS ir VIKOR panaudoti } \\
\text { ranguojant bankus pagal efektyvumą ir ištaisant } \\
\text { trijų bankų veiklos spragas. }\end{array}$ \\
\hline & $\begin{array}{l}\text { Ginevičius et al. } \\
2010\end{array}$ & $\begin{array}{l}\text { Imonès konkurencinės strategijos formavimas } \\
\text { oligopolinės rinkos sąlygomis. }\end{array}$ \\
\hline & $\begin{array}{l}\text { Ginevičius, } \\
\text { Podvezko } \\
\text { 2008a }\end{array}$ & $\begin{array}{l}\text { AHP, SAW, VS, GV, TOPSIS, VIKOR } \\
\text { daugiakriterinio vertinimo būdai buvo taikomi } \\
\text { vertinant nefinansinių ịmonių komercinę ir ūkinę } \\
\text { veiklą bei (išskyrus AHP metodą) naujų Europos } \\
\text { Sajungos narių konkurencingumą. }\end{array}$ \\
\hline
\end{tabular}




\section{6 lentelès pabaiga}

$\begin{array}{ll}\text { Stanujkic et al. } & \text { Ivairių daugiakriterinio vertinimo metodų (tarp jų ir } \\ 2013 & \text { VIKOR) panaudojimas, siekiant palyginti penkis } \\ & \text { skirtingus Serbijos komercinius bankus. }\end{array}$

Pagrindinę daugiakriterinio vertinimo metodų, paremtų kiekybiniais duomenimis, koncepciją geriausiai atskleidžia SAW (Simple Additive Weighting) metodas (Ginevičius, Podvezko 2008a, Ginevičius, Podvezko 2008b). Šis metodas yra vienas paprasčiausių ir dažniausiai taikomų sprendžiant sudètingas ekonominio ir socialinio pobūdžio problemas (Podvezko 2011). Šio metodo kriterijus $S_{j}$ yra visų svertinių kriterijų reikšmių suma:

$$
S_{j}=\sum_{i=1}^{n} w_{i} \tilde{r}_{i j},
$$

čia $w_{i}-i$-tojo kriterijaus svoris, $\tilde{r}_{i j}-i$-tojo kriterijaus normalizuota reikšmė $j$ ajam objektui.

SAW metodas yra pagrịstas klasikiniu duomenų normalizavimu:

$$
\tilde{r}_{i j}=\frac{r_{i j}}{\sum_{i=1}^{n} \tilde{r}_{i j}},
$$

čia $r_{i j}-i$-tojo rodiklio reikšmè $j$-tajam objektui.

Geriausia kriterijaus $S_{j}$ reikšmė yra didžiausia (Ginevičius, Podvezko 2008a; Ginevičius, Podvezko 2008b, Podvezko 2011).

Kitas vienas paprasčiausių metodų yra visų rodiklių vienetų suma (VS). Metodo kriterijus $V_{j}$ kiekvienam iš tiriamų objektų (j-tajam) apskaičiuojamas pagal šią formulę:

$$
V_{j}=\sum_{i=1}^{m} m_{i j},
$$

čia $m_{i j}-i$-tojo rodiklio vieta $j$-tajam objektui (tenkinant sąlygą $1 \leq m_{i j} \leq m$ ). Geriausią kriterijų $V_{j}$ atitinka mažiausia reikšmè. Šiam metodui būdinga tai, kad kriterijaus $V_{j}$ reikšmès nepriklauso nuo to, ar bus normalizuoti pradiniai duomenys, ir nuo rodikių svorių $\omega_{\mathrm{i}}$ reikšmių $(i=1, \ldots, m)$. Tačiau svarbu iš anksto nustatyti rodiklių pobūdị (maksimizuojantys ar minimizuojantys rodikliai). Atitinkamai, esant poreikiui, minimizuojančius rodiklius galima pertvarkyti ị maksimizuojančius pagal formulę: 


$$
\tilde{r}_{i j}=\frac{\min _{j} r_{i j}}{r_{i j}},
$$

čia $r_{i j}-i$-tojo rodiklio reikšmė $j$-tajam objektui.

Pasak Ginevičiaus ir Podvezko (2008a), šis metodas labiausiai tinka pradiniam vertinimui, tačiau ji naudojant, galutiniai rezultatai mažai skiriasi nuo gautų pritaikius kur kas sudètingesnius matematinius metodus.

Vertinant i̇monių veiklą naudojami paprastesni metodai (tokie kaip VS visų rodiklių vietų suma arba visų rodiklių normalizuotų reikšmių geometrinis vidurkis) buvo papildyti tobulesniais metodais - TOPSIS ir VIKOR, kuriuos siūloma naudoti ir šiame disertaciniame darbe.

TOPSIS metodas paremtas vektorine normalizacija:

$$
\tilde{r}_{i j}=\frac{r_{i j}}{\sqrt{\sum_{j=1}^{n} r_{i j}^{2}}},
$$

čia $\tilde{r}_{i j}-i$-tojo rodiklio normalizuota $j$-tojo objekto reikšmè.

Geriausias $\left(V^{*}\right)$ ir blogiausias $(V)$ sprendiniai skaičiuojami pagal formules:

$$
\begin{aligned}
& V^{*}=\left\{V_{1}^{*}, V_{2}^{*}, \ldots, V_{n}^{*}\right\}=\left\{\left(\max _{j} \omega_{i} r_{i j} / i \in I_{1}\right),\left(\min _{j} \omega_{i} \tilde{r}_{i j} / i \in I_{2}\right)\right\} \\
& V^{-}=\left\{V_{1}^{-}, V_{2}^{-}, \ldots, V_{n}^{-}\right\}=\left\{\left(\min _{j} \omega_{i} r_{i j} / i \in I_{1}\right),\left(\max _{j} \omega_{i} \tilde{r}_{i j} / i \in I_{2}\right)\right\},
\end{aligned}
$$

čia $I_{I}-$ maksimizuojamų rodiklių indeksų aibė; $I_{2}-$ minimizuojamų rodiklių indeksų aibè, $\omega_{i}-i$-tojo rodiklio svoris $\left(\sum_{i=1}^{n} \omega_{i}=1\right)$.

Tada skaičiuojamas kiekvieno lyginamojo varianto bendras atstumas: $D_{j}^{*}-$ iki geriausių sprendinių, $D_{j}^{-}-$iki blogiausių sprendinių:

$$
\begin{aligned}
& D_{j}^{*}=\sqrt{\sum_{i=1}^{n}\left(\omega_{i} \tilde{r}_{i j}-V_{i}^{*}\right)^{2}}, \\
& D_{j}^{-}=\sqrt{\sum_{i=1}^{n}\left(\omega_{i} \tilde{r}_{i j}-V_{i}^{-}\right)^{2}} .
\end{aligned}
$$

Galiausiai pagrindinis kriterijus $C_{j}^{*}$ apskaičiuojamas pagal šią formulę: 


$$
C_{j}^{*}=\frac{D^{-}}{D_{j}^{*}+D_{j}^{-}},
$$

čia $(j=1, \ldots, n)$, o $C_{j}^{*}$ turi tenkinti šią lygybę $\left(0 \leq C_{j}^{*} \leq 1\right)$.

Didžiausia kriterijaus $C_{j}^{*}$ reikšmè reiškia geriausią variantą. Lyginamieji variantai turi būti išdèstyti (suranguoti) mažèjančia tvarka (Ginevičius, Podvezko 2008a).

VIKOR metodu taip pat vertinamas atstumas iki geriausio sprendinio varianto ir siūlomi kompromisiniai variantai, jeigu vertinimo kriterijai yra prieštaringi. Maksimizuojant rodiklius, naudojama tokia normalizacija:

$$
\tilde{r}_{i j}=\left(\max _{j} r_{i j}-r_{i j}\right) /\left(\max _{j} r_{i j} / \min _{j} r_{i j}\right),
$$

čia $\widetilde{r}_{i j}$ turi tenkinti šią lygybę $\left(0 \leq \widetilde{r}_{i j} \leq 1\right)$.

Taikant VIKOR metodą naudojami trys vertinimo kriterijai: $S_{j}, R_{j}, Q_{j}(j=$ $1, \ldots, n)$. Kriterijai apskaičiuojami pagal šis formules:

$$
\begin{gathered}
S_{j}=\sum_{i=1}^{n} \omega_{i} \tilde{r}_{i j}, \\
R_{j}=\max _{i}\left(\omega_{i} \tilde{r}_{i j}\right), \\
Q=\frac{v\left(S_{j}-S^{*}\right)}{S^{-}-S^{*}}+\frac{(1-v)\left(R_{J}-R^{*}\right)}{\left(R^{-}-R^{*}\right)},
\end{gathered}
$$

čia $S^{*}=\min _{j} S_{j}, \quad S^{-}=\max _{j} S_{j}, \quad R^{*}=\min _{j} R_{j}, \quad R^{-}=\max _{j} R_{j} . V$ yra daugumos kriterijus, strateginis svoris $(v=0,5)$.

Pagrindinis apibendrintas kriterijus yra $Q_{j}$. Mažiausios $S_{j}, R_{j}, Q_{j}$ reiškia geriausius vertinimo variantus. Lyginamieji variantai turi būti išdèstyti (suranguoti) didejjančia tvarka (Ginevičius, Podvezko 2008a).

COPRAS metodo pagrindinis kriterijus $Z_{j}$ apskaičiuojamas pagal šią formulę:

$$
Z_{j}=S_{+j}+\frac{S_{-\min } \sum_{j=1}^{n} S_{-j}}{S_{-j} \sum_{j=1}^{n} \frac{S_{-\min }}{S_{-j}}},
$$


čia $S_{+j}=\sum_{i=1}^{n} \omega_{j} \tilde{r}_{+i j}$, t. y. maksimizuotu kriterijų $\tilde{r}_{+i j}$ svertiniu verčių suma. $S_{-j}=\sum_{i=1}^{n} \omega_{j} \tilde{r}_{-i j}$ naudojama remiantis tokia pačia logika, bet minimizuojant kriterijus.

Taip pat svarbu paminèti tai, kad siekiant normalizuoti pradinius duomenis, reikia naudoti klasikinę duomenų normalizavimo formulę (Ginevičius, Podvezko 2008b, Podvezko 2011):

$$
\tilde{r}_{i j}=\frac{r_{i j}}{\sum_{i=1}^{n} \tilde{r}_{i j}} .
$$

Kadangi kiekvienas daugiakriterinis vertinimo metodas turi savo vidinę logiką, privalumų, trūkumų ir ypatumų, metodų kriterijų reikšmès bei atitinkamai rangavimo rezultatai gali tarpusavyje skirtis (Ginevičius et al. 2004b, Ginevičius, Podvezko 2007). Todèl, siekiant, kad galutiniai rezultatai būtų kuo tikslesni, siūloma nustatyti visų vertinimų vidurkį. Tačiau šioje vietoje gali kilti kita problema - kokie metodai yra tinkami ir gali būti taikomi kartu viename ,pakete“. Pats paprasčiausias rodiklis sprendžiant šią problemą yra koreliacinio ryšio tarp daugiakriterinių vertinimo metodų nustatymas (Ginevičius et al. 2004b, Ginevičius, Podvezko 2008a). Ginevičius, Podvezko (2008a) siūlo nustatyti koreliacinị ryši lyginant kiekvieną iš daugiakriterinio vertinimo būdų su vienu baziniu daugiakriterinio vertinimo metodu (pavyzdžiui, su SAW metodu), galima teigti, jog kiekvieno daugiakriterinio vertinimo metodo lyginimas su kiekvienu metodu tikrai nepablogintų rezultatųpriešingai, galètų užtikrinti dar tikslesnị rezultatą, eliminuojant netinkamą ar netinkamus metodus iš ,paketo“.

\subsection{Antro skyriaus išvados}

1. Siekiant patvirtinti İSA kompleksinio vertinimo sistemos sukūrimo poreikį, antrame skyriuje buvo tiriamas komercinių bankų Lietuvoje brandumo lygis socialinès atsakomybės srityje. Nustatyta, jog bankai atitinka ketvirtą brandumo lygi socialinès atsakomybès srityje bei ịžvelgta gana ryški tendencija - nors bankų sąmoningumo lygis aukštas, požiūris platus ir socialinès atsakomybès ataskaitas jie 
įtraukia ne tik ị metines banko ataskaitas, tačiau praktiškai socialinès atsakomybès principai bankuose vis dar nėra integruoti i visus veiklos procesus. Šis ribotumas išryškina disertacinio darbo problemos aktualumą.

2. İvertinus komercinių bankų brandumo lygị socialinès atsakomybės srityje, patvirtinta prielaida, jog augant brandumo lygiui, dideja poreikis integruoti socialinès atsakomybès aspektus $\mathfrak{i}$ vis daugiau sričių, procesų ir pan. Tai atitinkamai turètų sąlygoti ir finansuojamų i̇monių socialinès atsakomybès vertinimo poreikį.

3. Siekiant sudaryti ịmonių socialinès atsakomybès kompleksinio vertinimo sistemą, skirtą finansuotojams, remiantis pirmame skyriuje pateiktu teoriniu pagrindu, suformuota galimai aktualiu finansuotojui İSA kriterijų sąranka. Ji buvo sudaryta iš 29 kriterijų, kurie grupuojami i keturias pagrindines kriterijų grupes: ekonominiai finansiniai, aplinkosauginiai, socialiniai ir valdymo.

4. İSA kompleksinio vertinimo sistemai sudaryti pasiūlyti šie daugiakriterinio vertinimo metodai:

4.1. AHP metodas, leidžiantis nustatyti sistemos kriteriju reikšmingumus išsikelto tikslo (İSA vertinimo) atžvilgiu. Šis metodas buvo pasirinktas kaip labiausiasi tinkamas įvertinti kokybinio pobūdžio kriterijus.

4.2. Kiti daugiakriterinio vertinimo metodai (COPRAS, TOPSIS, SAW, VIKOR, VS), padedantys nustatyti ir palyginti tarpusavyje kelių finansuojamų įmonių socialinès atsakomybės lygị. Šie metodai buvo pasirinkti dèl jų pritaikomumo, sprendžiant ekonominio pobūdžio problemas. 



\section{Imonių socialinès atsakomybès kompleksinio vertinimo sistemos praktinis modeliavimas ir pritaikymas}

Siekiant patikrinti antroje darbo dalyje pasiūlytų daugiakriterinio vertinimo metodų tinkamumą sudarant İSA kompleksinio vertinimo sistemą, atlikti empiriniai tyrimai praktiškai sumodeliuojant sistemą bei pritaikant ją trims realioms įmonėms - vieno Lietuvoje veikiančio komercinio banko klientėms. Tyrimo rezultatai publikuoti moksliniame žurnale (Slapikaitė 2016).

\subsection{Galutinès i̇monių socialinès atsakomybès kompleksinio vertinimo sistemos formavimas}

Modeliuojant İSA vertinimo sistemą buvo sudaryta ekspertų grupė E2. Joje buvo 9 ekspertai iš 4 skirtingų skandinaviško kapitalo bankų Lietuvoje. Ekspertai buvo pasirinkti atsižvelgiant ị jų veiklos sritị banke ir kompetencijos lygị. Tai daugiausia vadovai, projektu vadovai ir vadybininkai, tiesiogiai dirbantys arba kitaip susiję su verslo finansavimu (su verslo klientų rizikos vertinimu arba pardavimais). 
Apibendrinus ekspertinio tyrimo metu gautus rezultatus ir apskaičiavus kriterijų reikšmingumus, sudaryta Saaty (1994, 2008) pasiūlyta hierarchijos struktūra (3.1 pav.). Pagal gautus duomenis matyti, jog ekonominiai - finansiniai kriterijai yra svarbiausi finansuotojams vertinant įmonių socialinę atsakomybę. Šios kriterijų grupès reikšmingumas yra labai aukštas $(0,534)$, lyginant su likusiomis trimis grupėmis, o tai, savo ruožtu, parodo, jog net jeigu likę kriterijai (iš aplinkosauginių, socialinių bei valdymo kriterijų grupių) būtų maksimaliai ịvertinti, to neužtektų, kad įmonès socialinès atsakomybès lygis būtų pripažintas kaip itin aukštas. Iš finansinių kriterijų grupès reikšmingiausia yra skolų aptarnavimo $(0,617)$. Joje akivaizdžiai dominuoja skolų ir Ebitda santykis $(0,564)$, kuris yra vienas svarbiausių finansuojant imonę apskritai, ne tik vertinant jos socialinès atsakomybès lygi. Nustatant socialinès atsakomybès lygị imoneje, likvidumo ir pelningumo rodikliai yra panašiai reikšmingi $(0,177$ ir 0,206 atitinkamai). Pelningumo finansinių rodiklių grupejje labiausiai dominuoja Ebitda marža $(0,330)$, grynasis pelningumas $(0,124)$, veiklos pelningumas $(0,215)$ bei $\operatorname{ROE}(0,127)$. Likvidumo finansinių rodiklių grupejje - greitojo likvidumo koeficientas $(0,425)$.

Toliau svarbiausia kriterijų grupé, finansuojant klientus ir vertinant jų socialinę atsakomybę, yra valdymo kriterijų grupè $(0,227)$, kurioje reikšmingiausi yra korupcijos ir kyšininkavimo $(0,557)$ bei reputacijos $(0,36)$ rodikliai. Nors bendrai vertinant įmonių socialinę atsakomybę, valdymo kriterijų grupe nèra pati svarbiausia, tačiau norint apskritai finansuoti įmonę, šie kriterijai turi būti tam tikro priimtino lygio.

Iš socialinių kriterijų grupès $(0,135)$ reikšmingiausi yra su darbuotojais susiję klausimai - darbuotojų teisès, atitiktis darbo standartams ir pan. $(0,306)$ bei darbuotojų sauga ir sveikata $(0,412)$. Tai rodo, jog bankams aktualiausi i̇monių požiūris ir veiksmai, susiję su jų darbuotojais. Šie rodikliai taip pat gali glaudžiai sietis ir su kitu valdymo kriterijų grupès rodikliu - įmonès reputacija.

Iš aplinkosauginių kriterijų grupès aktualiausi yra tarša ir jos mažinimo $(0,197)$, oro taršos $(0,186)$ bei kietujų, pavojingų ir kitokių atliekų išmetimo $(0,204)$ klausimai, kurie taip pat gali glaudžiai sietis su kitais svarbiais rodikliais, pavyzdžiui, pelningumo ar valdymo (reputacijos).

Gauti kriterijų reikšmingumai dar kartą patvirtina pastebèjimą, ịrodytą analizuojant mokslinę literatūrą, jog ISA kriterijų sąranka yra individualus dalykas, labiausiai priklausantis nuo suinteresuotos šalies poreikių. 


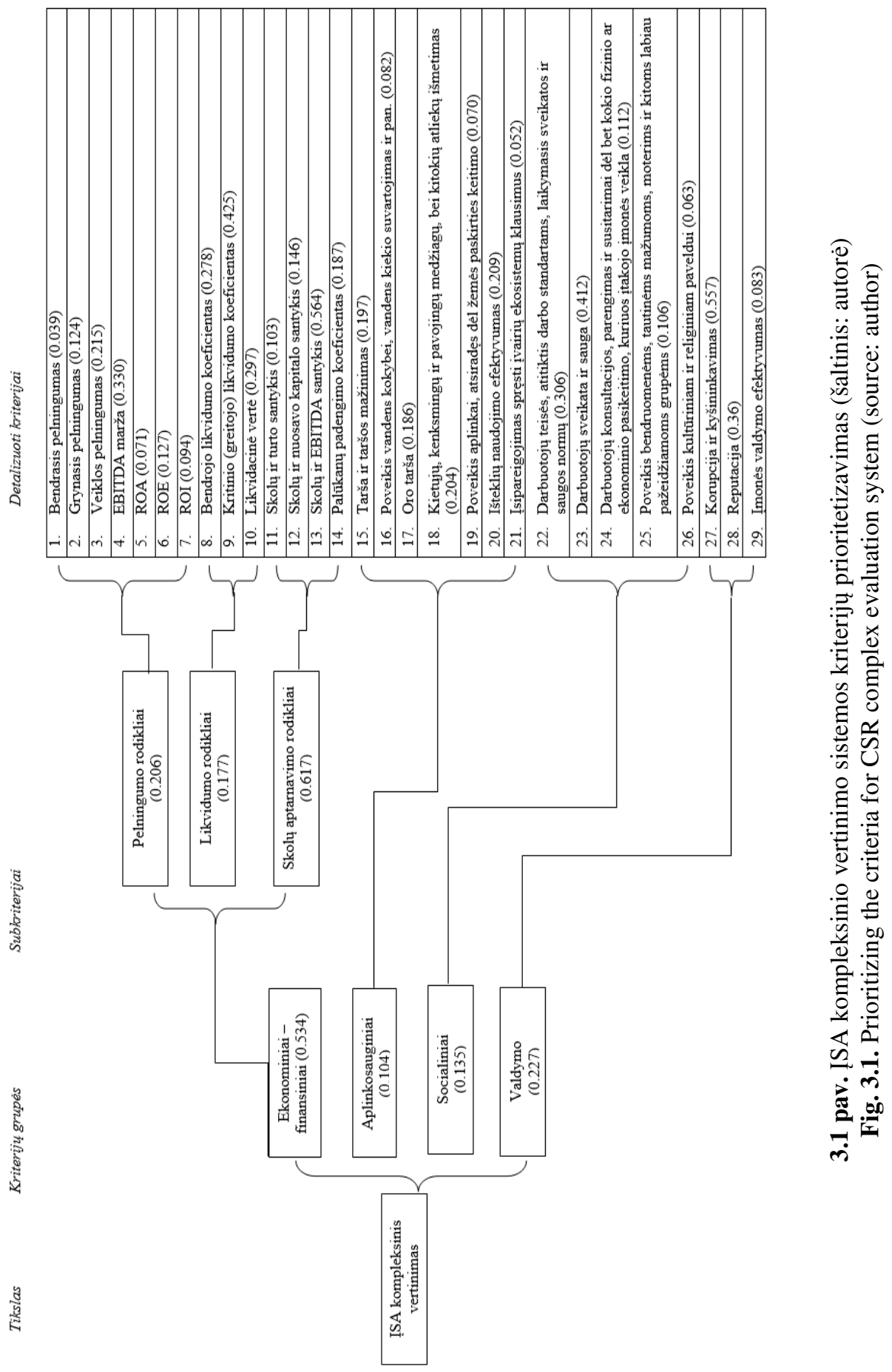


Nustačius ISA kompleksinio vertinimo sistemos kriterijų reikšmingumus, toliau reikalinga nustatyti bendrą ekspertu nuomonių sutapimo lygi konkordacijos koeficientą. Siekiant ji apskaičiuoti, visų pirma buvo suranguoti kriterijai pagal svarbumą. Svarbiausiam veiksniui buvo priskirta aukščiausia reikšmè, kuri yra lygi vienetui, mažesniam pagal ịtaką veiksniui priskirta kita reikšme -2 , ir t. t. Vienodiems vertinimams priskirtas tas pats rangas - eiliniu rangu aritmetinis vidurkis. Surangavus ekspertų vertinimus, toliau buvo apskaičiuotos kriterijų rangų sumų nuokrypių nuo bendro vidurkio kvadratų sumos $S_{k s}$ (pagal 2.9 formulę), kurios pateiktos Y priede.

Galiausiai apskaičiuoti konkordacijos koeficientai (3.1 lentelè). Rezultatų interpretavimas remiasi tokia logika: kuo labiau ekspertų vertinimai prieštaringi, tuo labiau konkordacijos koeficientas artejja link 0, ir priešingai, kuo ekspertų nuomonè labiau vieninga, tuo labiau konkordacijos koeficientas arteja link 1. Anot Pridotkienès ir Pridotko (2012), ekspertų nuomonė laikoma pakankamai vieninga, jeigu konkordacijos koeficientas yra ne mažiau 0,6.

Kaip jau buvo minèta antrame skyriuje, ekspertinis vertinimas remiasi prielaida, jog sprendimas gali būti gautas tik ịvertinus ekspertų nuomonių suderinamumą. Kadangi mokslininkai ne visais atvejais siūlo skaičiuoti matricos suderinamumo laipsni $S_{S}$ (Podvezko 2006, Pridotkiené, Pridotkas 2012, Baležentis, Žalimaitė 2011), šiame tyrime siūloma skaičiuoti tik bendrą ekspertų vertinimo suderinamumą - konkordancijos koeficientą $(W)$.

3.1 lentelè. Konkordancijos koeficientai ir jų reikšmingumai (šaltinis: autorè)

Table 3.1. Concordance coefficients and their significances (source: author)

\begin{tabular}{lccccc}
\hline \multicolumn{1}{c}{ Kriterijai } & $S_{k s}$ & $W$ & $\chi^{2}$ & $\chi_{k r}$ \\
\hline \multirow{2}{*}{$\begin{array}{l}\text { Ekonominiai }- \\
\text { finansiniai }\end{array}$} & Pelningumo & 1307 & 0,58 & 31,12 & 12,59 \\
\cline { 2 - 6 } & Likvidumo & 12,50 & 0,08 & 1,39 & 5,99 \\
\cline { 2 - 6 } & Skolų apt. & 234 & 0,58 & 15,60 & 7,81 \\
\hline Aplinkosauginiai & 1328 & 0,59 & 31,62 & 12,59 \\
\hline Socialiniai & 587 & 0,72 & 26,09 & 9,49 \\
\hline Valdymo & 134 & 0,83 & 14,89 & 5,99 \\
\hline & & & & \\
\hline $\begin{array}{l}\text { Ekonominių - finansinių } \\
\text { rodiklių grupe }\end{array}$ & 126 & 0,78 & 14 & 5,99 \\
\hline & & & & \\
\hline Kriterijų grupés & 249,50 & 0,62 & 22,18 & 7,81 \\
\hline
\end{tabular}


Gauti rezultatai parodè, jog nors konkordacijos koeficientų reikšmės yra gana žemos, tačiau vis dar priimtino lygio (išskyrus likvidumo rodiklių grupę) konkordacijos koeficientų reikšmès vyrauja nuo 0,58 iki 0,83 . Likvidumo rodiklių grupès konkordacijos koeficiento reikšmè šiuo atveju yra nepakankama $(W=0,08)$, kad galima būtų ją taikyti toliau sistemoje, todèl siūloma eliminuoti šią grupę kaip nepakankamai patikimą vertinant įmonių socialinę atsakomybę.

Sąlyginai mažas konkordancijos koeficientų reikšmes galëjo nulemti dvi priežastys:

1. Ekonominių - finansinių kriterijų įtraukimas ị įmonių socialinès atsakomybès vertinimą yra tiek moksline, tiek praktine prasme naujas dalykas. Nors mokslininkai pastaruosius kelis dešimtmečius gana nemažai diskutuoja apie finansinių rodiklių ir İSA sąsają, vis dèlto praktikams tai yra nauja sritis.

2. Kaip parodė Lietuvoje veikiančių bankų brandumo lygio socialinės atsakomybès srityje nustatymas, iš tiesų bankų pažangumas socialinès atsakomybès srityje skiriasi - didieji šalies komerciniai bankai labiau linkę integruoti socialinès atsakomybès aspektus savo veikloje. Būtent skirtingas bankų lygis galëjo sąlygoti ir nevienodus ISA kriterijų vertinimus.

Siekiant įsitikinti konkordancijos koeficientų reikšmingumu, taipogi buvo skaičiuojamos $\chi^{2}$ reikšmès (pagal 2.10 formulę), kurios vèliau palygintos su $\chi^{2}$ skirstinio kritinėmis reikšmėmis $\chi_{\mathrm{kr}}$ (su parinktu laisvès laipsniu ir reikšmingumo lygmeniu-0,05). Jeigu $\chi^{2}$ reikšmé viršija $\chi_{k r}-$ vadinasi, konkordancijos koeficientas priimtinas ir atitinkamai ekspertu vertinimas yra suderintas.

Gautos $\chi^{2}$ reikšmès (3.1 lentelè) patvirtino konkordacijos koeficientų reikšmingumus, o sąlyginai nemažas skirtumas tarp $\chi^{2}$ ir $\chi_{k r}$ reikšmių parodè gana aukštą patikimumo lygị. Be to, $\chi^{2}$ reikšmés nustatymas dar kartą patvirtino, jog likvidumo rodiklių grupé nèra tinkama tolimesniam naudojimui sudarant ISA kompleksinio vertinimo sistemą.

Nors likvidumo rodiklių grupès eliminavimas iš sistemos sumažina sistemą sudarančių kriterijų skaičių (lieka 26 kriterijai sistemoje), tačiau, manoma, jog dèl to sistemos kokybès reikšmingai nepablogèja. Likvidumo rodikliai nusako potencialias įmonès galimybes ịvykdyti savo trumpalaikius įsipareigojimus naudojant įmonès turtą. Dalị šių rodikliu informacijos nusako kiti vertinimo sistemoje esantys skolų aptarnavimo rodikliai - tokie kaip skolų ir turto santykis, skolu ir nuosavo kapitalo santykis. Pastarieji finansiniai rodikliai yra vieni svarbiausių, ị kuriuos bankai atsižvelgia finansuodami įmones.

Taipogi svarbu paminèti, jog eliminavus likvidumo rodiklių grupę, buvo reikalinga atitinkamai perskaičiuoti kai kurių kriterijų reikšmingumus. Galutinė 
İSA kompleksinio vertinimą sistemą sudarančių 26 kriterijų sąranka ir jų reikšmingumai pateikti Y priede.

\subsection{Sistemos praktinis patikrinimas}

Praktinis įmonių socialinès atsakomybės kompleksinio vertinimo sistemos igyvendinimas yra ne mažiau svarbus nei teorinis pačios sistemos formavimas. Numatoma, jog praktinị sistemos pritaikymą būtų galima skirstyti ì tris vertinimo sistemos panaudojimo galimybes (3.2 pav.):

1) siekiant nustatyti konkrečios ìmonès socialinès atsakomybès lygị siūlomoje 5 balų sistemoje;

2) siekiant nustatyti ir palyginti (suranguoti) kelias finansuojamas įmones socialinès atsakomybès srityje;

3) bei panaudojant sistemą norint atlikti detalesnę įmonės analizę, įžvelgti galimas rizikas.

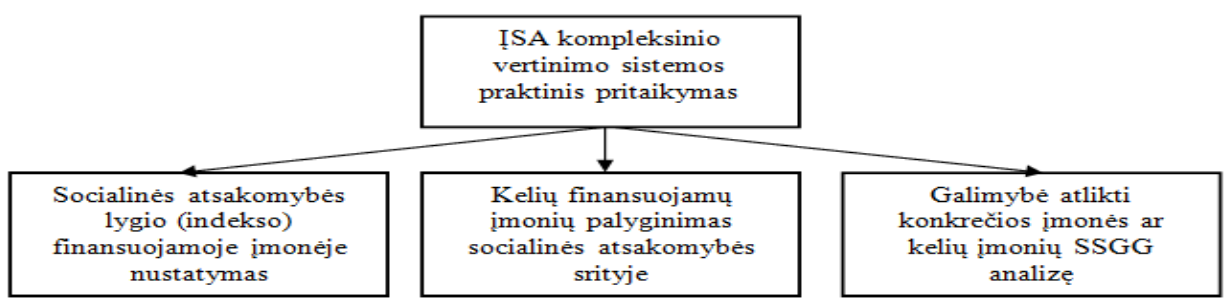

3.2 pav. İmonių socialinės atsakomybės kompleksinio vertinimo sistemos praktinio pritaikymo galimybès (šaltinis: autorè)

Fig. 3.2. Practical application possibilities of corporate social responsibility complex evaluation system (source: author)

Numačius ISA kompleksinio vertinimo sistemos praktinio pritaikymo galimybes, toliau svarbu numatyti, kaip bus vertinami İSA kriterijų sąranką sudarantys 26 kriterijai. Dažniausiai panašiais atvejais naudojama Likerto skalè, kurią taip pat siūloma naudoti ir finansuotojams, vertinantiems įmonių socialinès atsakomybės lygį. Šiuo atveju labai svarbu, kad ne tik pati sistema būtų aiški ir neapkrauta pertekline informacija, bet ir jos naudojimas būtų patogus ir paprastas - manoma, jog kuo daugiau pasirinkimų, tuo labiau sistema apkrauta ir gali neigiamai veikti jos naudotojus (pavyzdžiui, atmestinai sužymint kriterijus ir pan.). 
Todèl šiuo konkrečiu atveju siūloma naudoti 5 balų Likerto skalę, kurią sudaro tokie galimi pasirinkimo variantai (3.2 lentelè).

3.2 lentelè. 5 balų Likerto skalè (šaltinis: autorè)

Table 3.2. A 5-point Likert scale (source: author)

\begin{tabular}{|c|c|c|}
\hline $\begin{array}{l}\text { ISA kriterijų } \\
\text { vertinimas }\end{array}$ & Žymèjimas & Paaiškinimas \\
\hline Žemas (angl. Low) & 1 & $\begin{array}{l}\text { Imonè neatitinka arba praktiškai neatitinka } \\
\text { kriterijaus. }\end{array}$ \\
\hline $\begin{array}{l}\text { Vidutinis arba } \\
\text { netaikomas (angl. } \\
\text { Average or N/A) }\end{array}$ & 2 & $\begin{array}{l}\text { Imonè atitinka kriterijų tiek, kiek to reikalauja } \\
\text { teisès aktai ir / arba finansuotojas (reaktyvi } \\
\text { îmonė) arba kriterijus netaikomas dèl įmonès } \\
\text { veiklos specifikos, sektoriaus ir pan. }\end{array}$ \\
\hline $\begin{array}{l}\text { Aukštas } \\
\text { (angl. High) }\end{array}$ & 3 & $\begin{array}{l}\text { Imonè atitinka kriterijų ne vien dèl to, kad to } \\
\text { reikalauja teisès aktai ir / ar finansuotojas } \\
\text { (įmonès reaktyvus elgesys pereina ị } \\
\text { proaktyvumą). }\end{array}$ \\
\hline $\begin{array}{l}\text { Labai aukštas } \\
(\text { angl. Very high) }\end{array}$ & 4 & $\begin{array}{l}\text { Jeigu įmonè visiškai arba beveik atitinka kriterijų } \\
\text { (proaktyvi ̨̨monè). }\end{array}$ \\
\hline $\begin{array}{l}\text { Ypač aukštas } \\
\text { (angl. Excellent) }\end{array}$ & 5 & $\begin{array}{l}\text { Imonè visiškai atitinka kriterijų, taip pat jis } \\
\text { svarstomas strateginių klausimų lygmenyje ir } \\
\text { pan. (proaktyvi įmonè). }\end{array}$ \\
\hline
\end{tabular}

Siekiant praktiškai patikrinti ISA kompleksinio vertinimo sistemos pritaikomumą, buvo apklaustas vienas itin aukštos kvalifikcijos ekspertas (E3), dirbantis su verslo klientais, jų finansavimu ir įmonių socialinès atsakomybės vertinimu. Kadangi šis ekspertas buvo įtrauktas ir ị prieš tai buvusius ekspertinio tyrimo etapus (i E1 bei E2 ekspertų grupes), jis galejjo adekvačiai įvertinti tris savo klientus - banko finansuojamas įmones. Pagal banko verslo klientų sektorių suskirstymą, įmonė A - užsiima plastiko gamyba / prekyba, įmonė B automobiliu gamyba / prekyba, imonè $\mathrm{C}$ - naftos produktu prekyba. Kadangi vienas iš İSA kompleksinio vertinimo sistemos praktinio pritaikymo tikslų yra galimybė nustatyti finansuojamos įmonès socialinès atsakomybès lygį, pradiniai eksperto ịvertinimai (H priedas) buvo modifikuoti i 1 balo sistemą (pagal eksperto îvertinimą: 1 balas atitinka 0,$2 ; 2$ balai - 0,$4 ; 3$ balai - 0,$6 ; 4$ balai 0,$8 ; 5$ balai -1 , su sąlyga, kad atstumai tarp skirtingų vertinimų yra vienodi), o reikšmingumai $\omega_{\mathrm{i}}$ modifikuoti ị 5 balų sistemą (duomenys pateikti eliminavus likvidumo rodikių grupę, kuri buvo nustatyta kaip nepakankamai reikšminga). 
Kaip jau minèta antrame skyriuje, vertinant İSA buvo numatyta naudoti 5 daugiakriterinio vertinimo metodus: SAW, VS, TOPSIS, VIKOR bei COPRAS. Tačiau gavus ekspertinio vertinimo rezultatus, nutarta COPRAS metodą eliminuoti, nes jis netinka dèl savo taikymo specifikos - taikant COPRAS bent vienas kriterijus turi būti minimizuojantis (Podvezko 2011).

Taigi, daugiakriteriniam vertinimui galiausiai buvo pritaikyti keturi metodai - SAW, VS, TOPSIS ir VIKOR. Visų jų kriterijų reikšmès apskaičiuotos remiantis 2.11-2.24 formulèmis. Dažniausiai mokslininkų tyrimuose, taikant daugiakriterinius vertinimo metodus, yra taikomas normalizavimas, nes kriterijai būna ganėtinai skirtingo pobūdžio (pvz., ir maksimizuojantys, ir minimizuojantys), matavimo vienetų ir pan. Tačiau, atsižvelgiant ị tai, kad šioje ISA kompleksinio vertinimo sistemoje taikomi kriterijai yra tik maksimizuojančio pobūdžio, metodų reikšmės buvo apskaičiuotos dviem būdais: a) normalizuojant duomenis; b) nenormalizuojant duomenų. Naudojant duomenų normalizavimą, nustatyta, jog įmonė A turi aukščiausią socialinės atsakomybės lygi (3.3 lentelè).

3.3 lentelè. Trijų įmonių socialinès atsakomybès daugiakriterinio vertinimo rezultatai (duomenys normalizuoti) (šaltinis: autorè)

Table 3.3. The results of multicriteria evaluation of three companies ' corporate social responsibility (data are normalized) (source: author)

\begin{tabular}{|c|c|c|c|c|}
\hline & \multirow{2}{*}{ Metodas } & \multicolumn{3}{|c|}{ Imonès } \\
\hline & & A & B & $\mathrm{C}$ \\
\hline \multirow{2}{*}{ SAW } & Reikšmė & 1,862 & 1,832 & 1.299 \\
\hline & Vieta & 1 & 2 & 3 \\
\hline \multirow{2}{*}{ TOPSIS } & Reikšmė & 0,601 & 0,427 & 0.500 \\
\hline & Vieta & 1 & 3 & 2 \\
\hline \multirow{2}{*}{ VIKOR } & Reikšmė & 0,000 & 0,563 & 1.000 \\
\hline & Vieta & 1 & 2 & 3 \\
\hline \multirow{2}{*}{ VS } & Reikšmè & 58,500 & 59,500 & 38.000 \\
\hline & Vieta & 2 & 3 & 1 \\
\hline \multicolumn{2}{|c|}{ Vietų vidurkis } & 1,25 & 2,50 & 2,25 \\
\hline \multicolumn{2}{|c|}{ Bendra vieta } & 1 & 3 & 2 \\
\hline \multicolumn{2}{|c|}{ Vietų vidurkis be TOPSIS } & 1,33 & 2,33 & 2,33 \\
\hline \multicolumn{2}{|c|}{ Bendra vieta } & 1 & $2-3$ & $2-3$ \\
\hline
\end{tabular}


Tačiau apskačiavus metodų reikšmes, reikalinga nustatyti koreliacinị ryši tarp visų metodų porų tam, kad būtų galima įsitikinti, ar visi metodai tinkami naudoti sistemoje.

Pagal gautus koreliacijos koeficientus matyti, jog TOPSIS metodas nèra pats tinkamiausias taikant ši daugiakriterinio vertinimo metodų ,paketą“. Šio metodo koreliacinis ryšys su daugeliu kitų metodų yra labai silpnas (SAW ir TOPSIS - 0,14, TOPSIS ir VS - 0,05). Atsižvelgiant ị tai, siūloma TOPSIS metodą iš ,ppaketo“ eliminuoti. (3.4 lentelè).

3.4 lentelè. Koreliacinis ryšys tarp daugiakriterinio vertinimo metodų (duomenys normalizuoti) (šaltinis: autorè)

Table 3.4. The correlation between all multicriteria evaluation methods (data are normalized) (source: author)

\begin{tabular}{lccc}
\hline Metodai & SAW / TOPSIS & SAW / VIKOR & SAW / VS \\
\hline$\rho$ & 0,14 & $-0,85$ & 1,00 \\
\hline Metodai & TOPSIS / VIKOR & TOPSIS / VS & VIKOR / VS \\
\hline$\rho$ & $-0,64$ & 0,05 & $-0,80$ \\
\hline
\end{tabular}

Taigi, remiantis gautais galutiniais rezultatais (ir eliminavus TOPSIS metodą), aukščiausią socialinės atsakomybès lygị atitinka įmonẻ A, užsiimanti plastiko gamyba / prekyba. Lyginant su likusiomis dviem įmonèmis, ši įmonė užima pirmą vietą. Antrą vietą dalijasi ịmonè B, vykdanti automobilių gamybos / prekybos veiklą, bei įmonè C, prekiaujanti naftos produktais.

Kadangi ISA kompleksinio vertinimo sistemoje naudojamos tik maksimizuojančios reikšmès, taikant daugiakriterinio vertinimo metodus buvo skaičiuojama ir nenormalizuojant duomenų (3.5 lentelè).

3.5 lentelè. Trijų įmonių socialinės atsakomybės daugiakriterinio vertinimo rezultatai (duomenys nenormalizuoti) (šaltinis: autorè)

Table 3.5. The results of multicriteria evaluation of three companies' CSR (data are not normalized) (source: author)

\begin{tabular}{llccc}
\hline \multirow{2}{*}{ Metodas } & \multicolumn{3}{c}{ Imonès } \\
\cline { 3 - 5 } & & $\mathrm{A}$ & $\mathrm{B}$ & $\mathrm{C}$ \\
\hline \multirow{2}{*}{ SAW } & Reikšmé & 3,223 & 3,132 & 2,233 \\
\cline { 2 - 5 } & Vieta & 1 & 2 & 3 \\
\hline \multirow{2}{*}{ TOPSIS } & Reikšmé & 0,612 & 0,431 & 0,063 \\
\cline { 2 - 5 } & Vieta & 1 & 2 & 3 \\
\hline
\end{tabular}


3.5 lentelès pabaiga

\begin{tabular}{llccc}
\hline & \multirow{2}{*}{ Metodas } & \multicolumn{3}{c}{ Imonès } \\
\cline { 3 - 5 } & & $\mathrm{A}$ & $\mathrm{B}$ & $\mathrm{C}$ \\
\hline \multirow{2}{*}{ VIKOR } & Reikšmé & 1,051 & 0,952 & 0,295 \\
\cline { 2 - 5 } & Vieta & 3 & 2 & 1 \\
\hline \multirow{2}{*}{ VS } & Reikšmé & 45,500 & 44,500 & 66,000 \\
\cline { 2 - 5 } & Vieta & 2 & 1 & 3 \\
\hline \multicolumn{2}{l}{ Vietų vidurkis } & 1,75 & 1,75 & 2,5 \\
\hline \multicolumn{2}{l}{ Bendra vieta } & $1-2$ & $1-2$ & 3 \\
\hline
\end{tabular}

Nenormalizavus duomenų, TOPSIS metodas pasirode tinkamas taikyti su likusiais daugiakriterinio vertinimo metodais - koreliacinis ryšys yra labai stiprus (SAW ir TOPSIS - 0,97, TOPSIS ir VIKOR - 0,98, TOPSIS ir VS $(-0,93))$ (3.6 lentelè).

Pagal gautus galutinius rezultatus aukščiausią socialinès atsakomybės lygị atitinka dvi ịmonės - A ir B (dalijasi 1-2 vietas), o žemiausią socialinès atsakomybès lygị atitinka įmonè $\mathrm{C}$.

3.6 lentelè. Koreliacinis ryšys tarp daugiakriterinio vertinimo metodų (duomenys nenormalizuoti) (šaltinis: autorè)

Table 3.6. The correlation between all multicriteria evaluation methods (data are not normalized) (source: author)

\begin{tabular}{lccc}
\hline Metodai & SAW / TOPSIS & SAW / VIKOR & SAW / VS \\
\hline$\rho$ & 0,97 & 1,00 & $-0,99$ \\
\hline Metodai & TOPSIS / VIKOR & TOPSIS / VS & VIKOR / VS \\
\hline$\rho$ & 0,98 & $-0,93$ & $-0,99$ \\
\hline
\end{tabular}

Anot Podviezko, Podvezko (2015), skirtingus vertinimo rezultatus paprastai lemia skirtingi metodų taikomi normalizavimo būdai. Todèl norint praktiškai taikyti šiame darbe siūlomą ISA kompleksinio vertinimo sistemą, siūloma vadovautis tik antru daugiakriterinio vertinimo metodų ,paketu“, kuris apima visus keturis metodus (SAW, TOPSIS, VIKOR, VS), nes, kaip jau buvo minèta, šiame tyrime naudojamos tik maksimizuojančios reikšmès. Jeigu ị vertinimo sistemą būtų ịtrauktas bent vienas minimizuojančio pobūdžio kriterijus, būtų siūloma vadovautis pirmu daugiakriterinio vertinimo ,paketu“ (SAW, VIKOR, VS). 
Nenormalizavus duomenų, SAW metodas leidžia nustatyti konkrečios ịmonès konkretų socialinès atsakomybès lygị pagal 5 balų İSA brandumo lygių sistemą. Pavyzdžiui, ịmonė A ir įmonè B viršija vidutinị ịmonių socialinės atsakomybès lygi (3,223 ir 3,132 reikšmès atitinkamai), o įmonè C nesieka vidurkio - reikšmė 2,233. Taigi, šiame disertaciniame darbe siūloma ISA vertinimo sistema atveria papildomas sistemos taikymo galimybes - komerciniams bankams nusistačius tokio pobūdžio klientų ar projektų poreikį, siūlomą 5 balų lygio sistemą jie gali dalinti pagal savo ,apetitą“ (pvz., numatant cutoff's).

Vis dėlto atlikti skaičiavimai parodè, kad taikant šią ISA kompleksinio vertinimo sistemą, tikslesni rezultatai gaunami nenormalizuojant reikšmių. Ypač dèl TOPSIS metodo, kuriuo normalizuojant duomenis, buvo gauta neatitikimų (pvz., dalyba iš 0) ir tai galbūt iškraipe galutines kriterijų reikšmes bei sąlygojo prastus koreliacijos koeficientus su kitais metodais. Taigi, nenormalizuojant duomenų, visi keturi metodai, siekiant palyginti kelių finansuojamų i̇monių socialinès atsakomybès lygi, yra tinkami.

Taikant tik SAW metodą, galima nustatyti vienos finansuojamos įmonès brandumo lygi socialinès atsakomybès srityje. Kadangi šiuo atveju duomenys (reikšmingumai $\omega_{\mathrm{i}}$ ) buvo modifikuoti ị 5 lygių (balų) socialinès atsakomybės vertinimo sistemą, SAW metodu apskaičiuoti duomenys leido palyginti ne tik kelias įmones tarpusavyje, bet ir parode kiekvienos iš jų atskirai brandumo lygị socialinès atsakomybès srityje - i̇monès A ir įmonès B brandumo lygis yra aukštesnis nei vidutinis, o įmonès $\mathrm{C}$ žemesnis. Be abejo, tam, kad 5 brandumo lygių sistema būtų informatyvesnè ir detalesnè, visų pirma ji turètų būti sudaroma remiantis bendra finansuotojo politika socialinès atsakomybés srityje bei ,apetitu“ tokių ịmonių ar „žalių“ projektų finansavimui (pvz., tam, kad būtų galima identifikuoti ribas, angl. cut-off).

Be jau minètų sistemos praktinio pritaikymo galimybių, ISA kompleksinio vertinimo sistema leidžia identifikuoti i̇monès silpnąsias ir stipriąsias vietas socialinès atsakomybès srityje arba, kitaip sakant, atlikti SSGG analizę. Ši vertinimo sistemos pritaikymo galimybé galètų būti išnaudota ir kaip konkurencinis pranašumas prieš kitus bankus.

Ekonominis İSA kompleksinio vertinimo sistemos efektas gali būti suprantamas kaip kelių žingsnių piramidè, kurios pradžia yra finansuojamų i̇monių socialinès atsakomybès lygio nustatymas, o galutinis rezultatas prielaidos ekonominès sėkmès ciklui veikti.

Tinkamas ir savalaikis įmonių socialinès atsakomybès lygio nustatymas padeda ne tik geriau pažinti klientus, bet geriau ịvertinti ir valdyti galimas su klientais susijusias rizikas bei efektyviau valdyti turimus išteklius - tai atitinkamai gerina banko paskolų portfelio kokybę. Geresnė banko paskolų portfelio kokybė reikalauja mažesnių atidèjinių paskoloms ir gerina bendrus 
bankos veiklos rodiklius (likvidumo, kapitalo pakankamumo, pelningumo ir pan.) (3.3 pav.).

Finansuojamų ịmonių socialinès atsakomybès lygio nustatymas

Geresnè banko paskolụ portfelio kokybè

Geresni banko veiklos rodikliai

Aukštesnis banko patikimumo ir saugumo lygis

3.3 pav. ISA kompleksinio vertinimo sistemos, skirtos finansuotojui, poveikis ekonominès sèkmès ciklui (šaltinis: autorè)

Fig. 3.3. CSR complex evaluation system's effect for the cycle of economic success (source: author)

Visa tai sąlygoja tvarią banko veiklą ir sudaro prielaidas ekonominès sėkmès ciklui veikti.

\subsection{Trečio skyriaus išvados}

1. Tyrimo rezultatai parodè, jog vertinant finansuojamų įmonių socialinę atsakomybę, komerciniams bankams svarbiausia yra ekonominių - finansinių kriterijų grupè (jos grupès reikšmingumas 0,534), kurioje svarbiausios yra skolų aptarnavimo ir pelningumo subkriterijų grupès. Todèl, galima teigti, jog gauti kriterijų grupių ir kriterijų reikšmingumai patvirtina mokslininkų prielaidas, jog įmonių veiklos rezultatai turi ịtakos įmonių socialinès atsakomybès lygiui.

2. Ekspertų nuomonių suderinamumo lygis nustatytas apskaičiuojant konkordacijos koeficientus. Konkordacijos koeficientų reikšmès, išskyrus likvidumo rodiklių grupę, vyraujančios tarp $W=0,58$ ir $W=$ 0,83 , parodé, jog rezultatai yra pakankamai patikimi, kad būtu galima juos naudoti praktiškai taikant sistemą. Rezultatu patikimumą patvirtino ir konkordacijos koeficientų reikšmingumų $\left(\chi^{2}\right)$ įverti- 
nimas. Likvidumo rodiklių (subkriterijų) grupè dèl itin mažo konkordancijos koeficiento $(W=0,08)$ yra nepriimtina, todèl buvo sudarant galutinę İSA kompleksinio vertinimo sistemą šios subkriterijų grupès buvo atsisakyta.

3. Atmetus likvidumo rodiklių grupę, buvo suformuota galutinè İSA kompleksinio vertinimo sistema, kurią sudaro 26 kriterijai iš keturių kriterijų grupių: ekonominių - finansinių, aplinkosauginių, socialinių bei valdymo.

4. Siekiant patikrinti ISA kompleksinio vertinimo sistemos pritaikomumą praktiškai, buvo suformuotas daugiakriterinio vertinimo metodu „,paketas“, kuri sudaro SAW, TOPSIS, VIKOR ir VS metodai. Dèl maksimizuojančio pobūdžio reikšmių ir stipraus koreliacinio ryšio tarp vertinimo metodų, pasiūlyta naudoti visus metodus apimantị daugiakriterinio vertinimo metodų „paketą“, nereikalaujantị kriterijų reikšmių normalizavimo.

5. Praktinès İSA kompleksinio vertinimo sistemos pritaikymo galimybès yra gana plačios - galima ne tik palyginti kelias įmones tarpusavyje, bet ir nustatyti vienos ịmonès socialinès atsakomybès lygi pasiūlytoje 5 balu brandumo lygių sistemoje. Be to, finansuotojui papildomai pritaikius SSGG metodą, galima dar labiau praplèsti finansuojamų i̇monių analizę - geriau įžvelgti galimas rizikas bei numatyti neišnaudotas bendradarbiavimo su įmonėmis galimybes. 



\section{Bendrosios išvados}

1. Atlikus literatūros analizę, nustatyta, jog siekiant išlaikyti aukštą finansuotojų saugumo ir patikimumo lygi, pagerinti paskolų portfelio kokybę, efektyviau valdyti turimus resursus bei prisidèti prie valstybès socialinio ir ekonominio augimo, vis daugiau finansuotojų dèmesio ir reikšmès turi būti skiriama socialinès atsakomybès sričiai. Tinkamai atliktas finansuojamų i̇monių socialinès atsakomybès vertinimas šiandien yra vienas pagrindinių kelių siekiant tvarios bankininkystès tikslų bei užtikrinant ekonominès sèkmès ciklo veikimą.

2. Mokslinès literatūros analizè atskleidè, jog ịmonių socialinè atsakomybė vis dèlto yra individualus kiekvienos įmonès klausimas, o İSA vertinimo metodų ribotumas sudare prielaidas sukurti unikalią imonių socialinès atsakomybès kompleksinio vertinimo sistemą, skirtą finansuotojui. Be to, poreikis buvo patvirtintas ir praktiškai nustačius gana aukštą bankų brandumo lygi socialinès atsakomybès srityje ir tokiu būdu patvirtinant prielaidą, jog kuo aukštesnis banko brandumo lygis socialinès atsakomybès srityje, tuo labiau bankas linkęs integruoti İSA aspektus savo veikloje.

3. Remiantis J. Elkingtono Trijų ramsčių teorija, kitų mokslininkų tyrimais socialinès atsakomybès srityje bei praktikų rekomenda- 
cijomis tvarios bankininkystės srityje, sudarytas teorinis pagrindas İSA kompleksinei vertinimo sistemai suformuoti. Nustatyti aktualūs finansuotojams įmonių socialinès atsakomybès kriterijai sugrupuoti ị keturias pagrindines kriterijų grupes: ekonominę - finansinę, aplinkosauginę, socialinę ir valdymo. Skirtingo pobūdžio kriterijai, nusakantys sistemos kompleksiškumą ir ịvairiapusiškumą, toliau panaudoti sudarant ISA kompleksinio vertinimo sistemą.

4. ISSA kompleksinio vertinimo sistemos kriterijų reikšmingumams nustatyti pasitelktas plačiai naudojamas AHP metodas, kurio ekspertinio vertinimo patikimumas ivvertintas apskaičiuojant konkordacijos koeficientus. Nustačius kriteriju patikimumo lygi, buvo eliminuota viena ekonominių - finansinių subkriterijų grupé (likvidumo rodikliai), kaip nepakankamai patikima ir netinkama naudoti sistemai $(W=0,08)$. Galutinai suformuotą ISA kompleksinę vertinimo sistemą sudaro 26 kriterijai. Likusių kriterijų patikimumo lygiai, nors ir priimtini (svyruoja tarp $W=0,58$ ir $W=0,83$ ), bet sąlyginai žemi, atskleide potencialą ir tolesnių tyrimų poreikị, pavyzdžiui, išsamiau tiriant finansinių kriterijų (rodiklių) ir İSA sąsają, taip pat atskleide esamos situacijos specifiką - Lietuvoje veikiančių komercinių bankų socialinès atsakomybès lygis yra skirtingas.

5. Suformuota galutinė ISA kompleksinio vertinimo sistema leido patikrinti šios sistemos pritaikomumą trijų pasirinktų įmonių, veikiančių skirtinguose pramonès sektoriuose, pagrindu. Keturių daugiakriterinio vertinimo metodų (SAW, TOPSIS, VIKOR ir VS) tinkamumas ISA kompleksinio vertinimo sistemai buvo patikrintas nustatant koreliacinị ryši tarp skirtingu metodų. Atsižvelgiant ị tai, jog visos sistemos reikšmès yra tik maksimizuojančio pobūdžio ir nereikalauja reikšmių normalizavimo, buvo nutarta naudotị pilną daugiakriterinio vertinimo metodų ,paketą“. ISA kompleksinio vertinimo sistema atskleide šias sistemos praktinio panaudojimo galimybes finansuotojui:

5.1. Pasitelkiant SAW metodo rezultatus, galima nustatyti finansuojamos įmonés socialinès atsakomybès lygị šiame darbe pasiūlytoje 5 balų brandumo lygių sistemoje. Tai leistų finansuotojui geriau valdyti kredito riziką.

5.2. Bendras visų daugiakriterinio vertinimo metodų paketo pritaikymas leidžia palyginti kelių finansuojamų įmonių socialinès atsakomybès lygị. Tai leistų greičiau priimti 
sprendimus dèl įmonių finansavimo bei efektyviau paskirstyti turimus išteklius.

5.3. Papildomai pritaikius SSGG metodą, galima praplèsti finansuojamų įmonių analizę tokiais aspektais - geriau įžvelgti galimas rizikas bei numatyti neišnaudotas galimybes bendradarbiaujant su įmone. 



\section{Literatūra ir šaltiniai}

Adewale, M. T.; Rahmon, T. A. 2014. Does Corporate Social Responsibility Improve an Organization's Financial Performance? - Evidence from Nigerian Banking Sector. IUP Journal of Corporate Governance 13(4): 52-60.

Alhaddi, H. 2014. The Influence of Triple Bottom Line on Strategic Positioning: An Exploratory Case Study on Differentiation through Image. Journal of Management and Strategy 5(1): 55-72.

Antanavičienè, J.; Šimelytė, A. 2014. Verslo įmonès ekonomikos pagrindai. Mokomoji knyga, Vilnius: Technologija.

Arsoy, A. P.; Arabaci, O.; Ciftcioglu, A. 2012. Corporate Social Responsibility and Financial Performance Relationship: The Case of Turkey. Journal of Accounting and Finance 53: 159-176.

Atsakingas verslas. 2013. Socialine atsakomybè, kokybe ir standartai: veiksmingas, akivaizdus, bet neįvertintas ryšys, Nr. 2 [žiūrèta 201511 15]. Prieiga per internetą: <http://csrbaltic.lt/wp-content/uploads/2013/04/Atsakingas-verslas_Nr2.pdf>

Attig, N.; El Ghoul, S.; Guedhami, O.; Suh, J. 2013. Corporate Social Responsibility and Credit Ratings. Journal of Business Ethics 117(4): 679-694.

Babalola, Y. A.; Abiola, F. R. 2013. Financial Ratio Analysis of Firms: A Tool For Decision Making. International Journal of Management Sciences 1(4): 132-137. 
Bagdonienè, D.; Simanavičienè, A.; Aimuntas, G. 2011. System of balanced sustainable development indicators: the case of SC TEO. Management theory and studies for rural business and infrastructure development 1(25): 16-24.

Baležentis, A.; Žalimaitè, M. 2011. Ekspertinių vertinimų taikymas inovacijų plètros veiksnių analizèje: Lietuvos inovatyvių i̇monių vertinimas. Management theory and studies for rural business and infrastructure development 3(27): 23-31.

Barnett, M. L.; Salomon, R. S. 2006. Beyond Dichotomy: The Curvilinear Relationship Between Social Responsibility and Financial Performance. Strategic Management Journal 27(11): 1101-1122.

Banerjee, S. B. 2001. Corporate environmentalism: The Construct and its Measurement. Journal of Business Research 55(3): 177-191.

Bender, R.; Ward, K. 2002. Corporate Financial Strategy. 2-nd edition. Butterworth Heinemann, Oxford.

Benson, K. L.; Brailsford, T. J.; Humphrey, J. E. 2006. Do Socially Responsible Fund Managers Really Invest Differently? Journal of Business Ethics 65(4): 337-537.

Bernatonytè, D.; Vilkè, R.; Keizerienè, E. 2009. Ekonominès krizès poveikio Lietuvos smulkių ir vidutinių įmonių socialinei atsakomybei kryptys. Ekonomika ir vadyba 14: 229-236.

Birindelli, G.; Ferretti, P.; Intonti, M.; Iannuzzi, A. P. 2015. On the Drivers of Corporate Social Resposnibility in the Banks: Evidence from an Ethical Rating Model. Journal of Management \& Governance 19(2): 303-340.

Birkin, F.; Polesie, Th.; Lewis, L. 2009. A new business model for sustainable development: an exploratory study using the theory of constraints in Nordic organizations. Business Strategy \& the Environment 18(5): 277-290.

Bowen, H. R. 1953. Social Responsibilities of the Businessman. New York: Harper \& Row.

Bureau Veritas. Socialinis atsakingumas ir SA8000 standartas [žiūrèta 20150531 ]. Prieiga per internetą: <http://www.bureauveritas.lt/wps/wcm/connect/b941398c-bb044a64-89b6-f6cc0d0fdfe1/Socialinis+atsakingumas+ir+SA8000+standartas_2009-0608f.pdf?MOD=AJPERES>

Carroll, A. B. 1979. A Three-Dimensional Conceptual Model of Corporate Performance. Academy of Management Review 4(4): 497-505.

Carroll, A. B. 1999. Corporate social responsibility evolution of a definitional construct. Business \& Society 38(3): 268-295.

Carroll, A. B. 1991. The pyramid of corporate social responsibility: toward the moral management of organizational stakeholder. Business Horizons 34(4): 39-48.

Carter, S. 2007. Socially Responsible Mutual Funds [žiūrèta 201512 15]. Prieiga per internetą: <http://www.investopedia.com/articles/mutualfund/03/030503.asp> 
Cavaco, S.; Crifo, P. 2014. CSR and Financial Performance: Complementarity Between Environmental, Social and Business Behaviours. Applied Economics 46(27): 3323-3338.

Chang, D.; Kuo, L.-R. 2008. The effects of sustainable development on firms' financial performance - an empirical approach. Sustainable Development 16(6): 365-380.

Clarke, T. 2007. The evolution of directors duties: bridging the divide between corporate governance and corporate social responsibility. Journal of General Management 32(3): 79-105.

Clarkson, M. B. E. 1995. A Stakeholder Framework for Analyzing and Evaluating Corporate Social Performance. Academy of Management Review 20(1): 92-117.

Corina, P.; Anca, V.; Fufezan, M. 2009. Indicators used for the performance measurement of sustainable development. Annals of the University of Oradea, Economic Science Series 18(4): 421-425.

Cortez, M. C.; Silva, F.; Areal, N. 2009. The Performance of European Socially Responsible Funds. Journal of Business Ethics 87(4): 573-588.

Čiegis, R. 2008. Sustainable development dimensions and stages. Modelling the European Future: Integrating the Old and the New 4: 139-143.

Čiegis, R.; Grunda, R. 2007. Imonès transformavimo ì darnią įmonę procesas. Organizaciju vadyba: sisteminiai tyrimai 44: 19-34.

Čiegis, R.; Norkutè, R. 2012. Corporate Social Responsibility of the Banks in Lithuania in the Context of Sustainable Development. Management of Organizations: Systematic Research 63: 19-33.

Čiegis, R.; Ramanauskienè, J.; Martinkus, B. 2009. The Concept of Sustainable Development and its Use for Sustainability Scenarios. Engineering Economics 62(2): 28-37.

Dagilienè, L. 2008. Finansiniu vertinimo metodu parinkimas investavimo ir valdymo tikslams. Daktaro disertacija, Kaunas.

Dagilienè, L. 2014. Socialine apskaita: teoriné argumentacija ir vertinimas. Kaunas: Technologija.

Daszynska-Zygadlo, K.; Slonski, T.; Zawadski, B. 2016. The Market Value of CSR Performance Across Sectors. Engineering Economics 27(2): 230-238.

Daujotaitè, D. 2006. Finansinis auditas. Vilnius: Vilniaus vadybos aukštoji mokykla.

Deal, T. E.; Kennedy, A. A. 1982. Corporate Cultures: The Rites and Rituals of Corporate Life. Addison-Wesley, Reading, MA.

Dean, K. L. 1998. The Chicken and the Egg Revisited: Ties Between Corporate Social Performance and the Financial Bottom Line. Academy of Management Executive 12(2): 99-100. 
Dhiman, S. 2008. Products, People, and Planet: The Triple Bottom-Line Sustainability Imperative. The Journal of Global Business Issues 2(2): 51-57.

Eko redakcija. 2011. Darnus vystymasis, raida ar plètra? [žiūrèta 201509 23]. Prieiga per internetą: <http://www.alfa.lt/straipsnis/11037699/darnus-vystymasis-raida-arpletra?ref=lnkgo\&utm_source=lnkgo\&utm_medium=responsive\&utm_campaign=infobl okai>

Elena, N. I. 2012. Company Performance Measurement and Reporting Methods. Annals of the University of Oradea, Economic Science Series 21(2): 700-707.

Elkington, J. 1994. Towards the sustainable corporation: win-win-win business strategies for sustainable development California Management Review 36(2): 90-100.

Elkington, J. 1997. Cannibals with forks. Triple bottom line of $21^{\text {st }}$ century business. Knygos apžvalga - Berkovics, D. 2010. Majeure Alternative Management, Paris, 20092010 [žiūrèta 201511 23]. Prieiga per internetą: <http://appli6.hec.fr/amo/Public/ Files/Docs/148_en.pdf>

Epstein, E. M. 1987. The Corporate Social Policy Process: Beyond Business Ethics, Corporate Social Responsibility and Corporate Social Responsiveness. California Management Review 29(3): 99-114.

Erguden, E.; Catlioglu, E. 2016. Sustainability Reporting Practiceses In Energy Companies With Topsis Method. Journal of Accounting \& Finance: 201-221.

European Commission. 2002. Communication from the Commission concerning corporate social responsibility: a business contribution to sustainable development [žiūrèta 201512 15]. Prieiga per internetą: <http://eur-lex.europa.eu/legal-content/EN/ ALL/?uri=CELEX:52002DC0347>

Fauzi, H. 2009. Corporate Social and Financial Performance: Empirical Evidence from American Companies. Globsyn Management Journal 3(1): 25-34.

Fauzi, H.; Idris, K. M. 2009. The Relationship of CSR and Financial Performance: New Evidence from Indonesian Companies. Issues in Social \& Environmental Accounting 3(1): 66-87.

Financial Ratio Analysis 2016 [žiūrèta 201603 15]. Prieiga per internetą: <http://www. myaccountingcourse.com/financial-ratios/>

Fongwa, E. A. 2010. Financial Participation for Sustainable Business Development. Journal of Business \& Economics 2(2): 228-244.

Freeman, R. E. 1984. Srategic management: a stakeholder approach. Boston: Pitman.

Gazzola, P. 2012. Social Performance Enhances Financial Performance. Benefits from CSR. Annals of the University of Oradea, Economic Science Series 21(1): 112-121.

Ginevičius, R. 2006. Daugiakriterinio vertinimo rodikliu svoriu nustatymas, remiantis ju tarpusavio squeika. Verslas: teorija ir praktika (Business: Theory and Practice). Volume 7, Issue 1: 3-13. 
Ginevičius, R.; Krivka, A.; Šimkūnaitè, J. 2010. The Model of Forming Competitive Strategy of an Enterprise Under the Conditions of Oligopolic Market. Journal of Business Economics and Management 11(3): 367-395.

Ginevičius, R.; Podvezko, V. 2007. The effect of complex evaluation the reliability of calculation results. The $4^{\text {th }}$ International Scientific Conference Business and Management '2006, Vilnius: Technika: 27-30.

Ginevičius, R.; Podvezko, V. 2008a. Daugiakriterinio vertinimo būdų suderinamumas. Verslas: teorija ir praktika (Business: Theory and Practice) 9(1): 73-80.

Ginevičius, R.; Podvezko, V. 2008b. Multicriteria Evaluation of Lithuanian Banks from the Perspective of their Reliability for Clients. Journal of Business Economics and Management 9(4): 257-267.

Ginevičius, R.; Podvezko, V.; Andruškevičius, A. 2004a. Statybos sistemų technologiškumo nustatymas AHP metodu. Ūkio technologinis ir ekonominis vystymasis (Technological and Economic Development of Economy) 10(4): 135-141.

Ginevičius, R.; Podvezko, V.; Mikelis, D. 2004b. Quantitative evaluation of economic and social development of lithuanian regions. Economics, Research papers 65: 67-81.

Glac, K. 2009. Understanding Socially Responsible Investing: The Effect of Decision Frames and Trade-off Options. Journal of Business Ethics 87: 41-55.

Global Reporting Initiative. About GRI [žiūrèta 201505 20]. Prieiga per internetą: $<$ https://www.globalreporting.org/Information/about-gri/Pages/default.aspx>

Global Reporting Initiative. 2011. Sustainability Reporting Guidelines [žiūrèta 201505 20]. Prieiga per internetą: <https://www.globalreporting.org/resourcelibrary/G3Guidelines-Incl-Technical-Protocol.pdf $>$

Goel, P. 2010. Triple Bottom Line Reporting: An Analytical Approach For Corporate Sustainability. Journal of Finance, Accounting and Management 1(1): 27-42.

Grundey, D. 2008. Applying sustainability principles in the economy. Technological and Economic Development of Economy 14(2): 101-106.

Gruževskis, B.; Vasiljevienè, N.; Moskvina, J.; Kleinaitė, I. 2006. Imoniu socialinè atsakomybè. Aktualūs socialinès politikos klausimai. Vilnius: Darbo ir socialinių tyrimų institutas, ISSN 1648-6269.

Gutierrez-Nieto, B.; Serrano-Cinca, C., Camon-Cala, C. 2016. A Credit Score System for Socially Responsible Lending. Journal of Business Ethics 133(4): 691-701.

Hayes, S. K. 2005. Socially Responsible Mutual Funds: Issues to Consider When Investing With Your Conscience. Journal of Financial Service Proffesionals 59(5): 5963.

Hamann, R. 2012. The business of development: revisiting strategies for a sustainable future. Environment 54(2): 18-29. 
Hardi, P.; Barg. S.; Hodge, T. 1997. Measuring Sustainable Development: Review of Current Practice. Winnipeg, Manitoba, Canada: International Institute for Sustainable Development.

Hollos, D.; Blome, C.; Foerstl, K. 2012. Does sustainable supplier co-operation affect performance? Examining implications for the triple bottom line. International Journal of Production Research 15(11): 2968-2986.

Hu, Vi-in.; Scholtens, B. 2014. Corporate Social Responsibility Policies of Commercial Banks in Developing Countries. Sustainable Development 22(4): 276-288.

Hueting, R.; Reijinders, L. 2004. Broad sustainability contra sustainability: the proper construction of sustainability indicators. Eco-efficiency as abandonment of the nature. Ecological Economics 38.

Investuotojų forumas. 2012. Etikos kodeksas [žiūrèta 201505 25]. Prieiga per internetą: <http://www.investorsforum.lt/lt/apie-mus/etikos-kodeksas>

ISO. ISO26000 - Social responsibility [žiūrèta 201511 12]. Prieiga per internetą: $<$ http://www.iso.org/iso/home/standards/iso26000.htm>

ISO ir kitų tarptautinių organizacijų standartai jūsų ịstaigai [žiūrèta 201511 12]. Prieiga per internetą: <http://www.isostandartai.lt/iso-26000-socialine-atsakomybe/>

Jackson, L. A.; Parsa, H. G. 2009. Corporate Social Responsibility and Financial Performance: a Typology for Service Industries. International Journal of Business Insights \& Transformation 2(2): 13-21.

Jeroen, D.; Kees, K. 2009. Socially Responsible Fixed-Income Funds. Journal of Business Finance and Accounting 36(1/2): 210-229.

Jiraporn, P.; Jiraporn, N. Boeprasert, A.; Chang, K. 2014. Does Corporate Social Responsibility (CSR) Improve Credit Ratings? Evidence from Geographic Identification. Financial Management 43(3): 505-531.

Johnson, H. L. 1971. Business in contemporary society: Framework and issues. Belmont, CA: Wadsworth.

Jothi, M.; Mathiraj, S. P. 2013. The Relationship Between Social Performance (SP) And Financial Performance (FP) of Public Sector Banks. Global Management Review 7(2): $1-10$.

Juozaitienè, L. 2007. Imonès finansai: analize ir valdymas. Šiauliai: VšI Šiaulių universiteto leidykla.

Jurkaitis, M.; Mažeika, D. Semaškaitè, K. 2011. Socialiai atsakingas verslas Lietuvoje [žiūrèta 201505 31]. Prieiga per internetą: <http://analize.lt/praktine-analize/socialiaiatsakingas-verslas-lietuvoje.html>

Juščius, V., Jonikas, D. 2013. Integration of CSR into Value Creation Chain: Conceptual Framework. Engineering Economics 24(1): 63-70. 
Kagan, R. A.; Gunningham, N.; Thornton, D. 2003. Explaining Corporate Environmental Performance: How Does Regulation Matter? Law and Society Review 37: 51-90.

Kalibatas, D.; Zavadskas, E. K.; Kalibaitienè, D. 2012. A method of multi-attribute assessment using ideal alternative: choosing an apartment with optimal indoor environment. International Journal of Strategic Property Management 16(3): 338-353.

Kalwarski, T. 2008. Do Good Investments are Holding up Better? Business Week 15(4092).

Keskin, B. 2013. The Evaluation of Financial Performance by Using Topsis and Electre Methods: a Research on Construction Sector Companies. Proceedings of the Multidisciplinary Academic Conference: 1-8.

Kleinaitè, I. 2007. İmonių socialinès atsakomybès gairès mažoms ir vidutinėms įmonèms ir geros praktikos pavyzdžiai. Atsakingo verslo praktika. Socialinès apsaugos ir darbo ministerija.

Kluwer Academic Publishers. Edited by Gass, S. I.; Harris, C. M. 2001. Encyclopedia of Operations Research \& Management Science. Straipsnis Saaty, T. L. Analytic Hierarchy Process: 19-28.

Kneževic, S.; Rakočevic, S. B.; Duric, D. 2011. Implementation and Restraints of Ratio Analysis of Financial Reports in Financial Decision Making. Management 61: 24-31.

Knox, S. 2007. Ramsden, J. J.; Aida, S. and; Kakabadse, A. eds. Corporate Social Responsibility and Business Decision Making. Spiritual Motivation: New Thinking for Business and Management. Basingstoke: Palgrave Macmillan, ISBN 978-0-230-54291-4.

Kotane, I.; Kuzmina-Merlino, I. 2012. Assessment of Financial Indicators for Evaluation of Business Performance. European Integration Studies 6: 216-224.

Kovaliov, R.; Snieška, V.; Simanavičius, A. 2009. Lietuvos autoverslo ịmonių požiūrio ị ISA vertinimas. Ekonomika ir vadyba 14: 294-300.

Krivka, A.; Stonkutè, E. 2015. Complex Analysis of Financial State and Performance of Construction Enterprises. Business, Management \& Education 13(2): 220-233.

Kucukvar, M.; Tatari, O. 2013. Towards a triple bottom-line sustainability assessment of the U.S. construction industry. International Journal of Life Cycle Assessment 18(5): 958-972.

Kvalitetas. 2014. ISO26000 [žiūrèta 2015 11 12]. Prieiga per internetą <http:// www.kvalitetas.lt/lt/iso-26000>

Lan, Z. J. 2012. 16 Financial Ratios for Analyzing a Company's Strengths and Weaknesses. AAll Journal 34(9): 18-22.

Lech, A. 2013. Corporate Social Responsibility and Financial Performance. Theoretical and Empirical Aspects. Comparative Economic Research 16(3): 49-62. 
Lee, S. Y.; Carroll, C. E. 2011. The Emergence, Variation, and Evolution of Corporate Social Responsibility in the Public Sphere, 1980-2004: The Exposure of Firms to Public Debate. Journal of Business Ethics 104(1): 115-131.

Lentner, C.; Szegedi, K.; Tatay, T. 2015. Corporate Social Responsibility in the Banking Sector. Public Finance Quarterly 1: 95-103.

Lietuvių kalbos žodynas [žiūrèta 201509 23]. Prieiga per internetą: $<$ http://www.lkz.lt/startas.htm>

Lietuvos Atsakingo Verslo Asociacija. Apie Mus [žiūrèta 201505 29]. Prieiga per internetą: <http://www.asociacijalava.lt/apie-mus.html>

Lietuvos Atsakingo Verslo Asociacija. 2016. Istatai [žiūrèta 201604 29]. Prieiga per internetą: <http://asociacijalava.lt/\%C4\%AFstatai.html>

Lietuvos Respublikos Seimas. 2012 m. gruodžio 13 d. Nr. XII-51, Vilnius. Nutarimas dèl Lietuvos Respublikos vyriausybès programos [žiūrèta 201502 10]. Prieiga per internetą: $\quad<\mathrm{http}: / /$ www.socmin.lt/lt/darbo-rinka-uzimtumas/imoniu-socialineatsakomybe-isa/apie-imoniu-socialine-atsakomybe.html>

Lietuvos Respublikos Socialinès Apsaugos ir Darbo Ministerija. 2016 Imoniu socialine atsakomybe [žiūrèta 201606 30]. Prieiga per internetą: <http://www.socmin.lt/lt/darborinka-uzimtumas/imoniu-socialine-atsakomybe-isa/nacionalinis-atsakingo-versloapdovanojimas.html>

Lietuvos Statistikos Departamentas. Suteiktos naujos paskolos nefinansinems korporacijoms ir namų ūkiams ir ju palükanų normos [žiūrèta 201703 05]. Prieiga per internetą: <http://www.lb.lt/stat_pub/statbrowser.aspx?group=8279\&lang=lt>

Lindgreen, A., Swaen, V. 2010. Corporate Social Responsibility. International Journal of Management Reviews 12(1): 1-7.

Lindgreen, A.; Swaen, V.; Johnston, W. J. 2008. Corporate Social Responsibility: An Empirical Investigation of U.S. Organizations. Journal of Business Ethics 85(2): 303323.

Lindgreen, A.; Swaen, V.; Maon, F. 2008a. Introduction: Corporate Social Responsibility Implementation. Journal of Business Ethics 85: 251-256.

Lindgreen A.; Swaen V.; Maon, F. 2008b. Thinking of the Organization as a System: The Role of Managerial Perceptions in Developing a Corporate Social Responsibility Strategic Agenda. Systems Research and Behavioural Science 25(3): 413-426.

Lindgreen A.; Swaen V.; Maon, F. 2009. Corporate Social Responsibility Within the Organization. Corporate. Reputation Review 12(2): 83-86.

Maignan, I.; Ferrell, O. C.; Ferrell, L. 2006. A Stakeholder Model for Implementing Social Responsibility in Marketing. European Journal of Marketing 39(9-10): 956-976. 
Maignan, I.; Ralston, D. A. 2002. Corporate Social Responsibility in Europe and the U. S.: Insights from Businesses' Self-Presentations. Journal of International Business Studies 33(3): 497-514.

Matei, M.; Voica, M. C. 2013. Social Responsibility in the financial and Banking Sector. Economic Insights - Trends and Challenges 65(1): 115-123.

Mathew, V. 2009. Sustainable enterpreneurship in small-scale business: application, concepts and cases. ICFAI Journal of Enterpreneurship Development 6(1): 41-61.

McPeak, Ch.; Huizi Bi, G. 2012. The Progress of Financial Performance by Corporate Social Responsibility Leaders From 2007 through 2011. Journal of Global Business Issues 6(1): 35-40.

McWilliams, A.; Siegel D. 2000. Corporate Social Responsibility and Financial Performance: Correlation or Misspecification? Strategic Management Journal 21(5): 603-610.

Miles, S. 2012. Stakeholders: essentially contested or just confused? Journal of Business Ethics 108(3): 285-298.

Millet, I. 1998. Ethical decision making using the analytic hierarchy process. Journal of Business Ethics 17(11): 1197-1204.

Moldan, B.; Dahl, A. L. 2007. Challenges to Sustainable Indicators. Moldan, H. T.; Dahl, A. (Eds). Measuring progress towards sustainability: assessment of indicators: a Project of SCOPE, the Scientific Committee on Problems of the Environment, of the Interbnational Council for Science. Washington, DC.

Monea, M. 2009. Financial Ratios - Reveal How a Business is Doing? Annals of the University of Petrosani, Economics 9(2): 137-144.

Moon, J. 2007. The contribution of corporate social responsibility to sustainable development. Sustainable development 15(5): 296-306.

NQA. ISO 14001:2004 or ISO 14001:2015. [online] [cited 12 November 2015]. Available from Internet: https://www.nqa.com/en-gb/certification/standards/iso-140012004

Oh, W.; Park, S. 2015. The Relationship Between Corporate Social Responsibility and Corporate Financial Performance in Korea. Emerging Markets Finance \& Trade 51: 8594.

Onat, N. C.; Kucukvar, M.; Tatari, O. 2014. Integrating triple bottom line input-output analysis into life cycle sustainability assessment framework: the case for US buildings. International Journal of Life Cycle Assessment 19(8): 1488-1505.

Parezanovic, T.; Bojkovic, N.; Petrovic, M.; Tarle, S. P. 2016. Evaluation of Sustainable Mobility Measures Using Fuzzy COPRAS Method. Management 78: 53-62.

Paužuolienè, J. 2010. Socialinès atsakomybès įtaka darniai verslo plètrai. Jaunuju mokslininku darbai 1(26): 115-121. 
Peloza, J.; Papania, L. 2008. The Missing Link Between Corporate Social Responsibility and Financial Performance: Stakeholder Salience and Identification. Corporate Reputation Review 11(2): 169-181.

Podvezko, V. 2005. Ekspertų įverčių suderinamumas. Ūkio technologinis ir ekonominis vystymas (Technological and Economic Development of Economy) 1(2): 101-107.

Podvezko, V. 2006. Neapibrèžtumo įtaka daugiakriteriniams vertinimams. Verslas: teorija ir praktika 7(2): 81-88.

Podvezko, V. 2009. Application of AHP Technique. Business Economics and Management. Volume 10, Issue 2: 181-189.

Podvezko, V. 2011. The Comparative Analysis of MCDA Methods SAW and COPRAS. Inžineriné ekonomika (Engineering Economics) 22(2): 134-146.

Podviezko, A.; Podvezko V. 2015. Influence of data transformation on multicriteria evaluation result. Procedia Engineering. Innovative solutions in construction engineering and management 122: 151-157.

Pridotkienė, J.; Pridotkas, R. 2012. Reikšmingų nefinansinių rodiklių nustatymas vertinant eksporto prekinio kredito riziką. Economics and Management 17(3): 10161020.

Pruskus, V. 2002. Verslo etika. Vilnius.

Pruskus, V. 2003. Verslo etika: laiko iššūkiai ir atsako galimybès. Vilnius: Enciklopedija.

Rakauskienė, G. 2013. Šalies konkurencingumo skatinimo sprendimų pagrįstumo didinimas. Ph.D. Thesis, Vilnius: Vilnius Gediminas Technical University (VGTU), Lithuania.

Rakauskienė, G.; Tamošiūnienė, R. 2013. Šalies konkurencingumo pokyčio optimizavimas. Verslo sistemos ir ekonomika (Business Systems and Economics) 3(2): 167176.

Robecosam. Facts \& Figures [žiūrèta 201505 13]. Prieiga per internetą: <http://www.robecosam.com/en/about-us/facts-and-figures.jsp>

Rodgers, W.; Choy, H. L.; Guiral, A. 2013. Do Investors Value a Firm's Commitment to Social Activities? Journal of Business Ethics 114(4): 607-623.

Rodriguez, S. I.; Roman, M. S.; Sturhahn, S. C.; Terry, E. H. 2002. Sustainability Assessment and Reporting for the University of Michigan's Ann Arbor Campus. University of Michigan [žiūrèta 201505 15]. Prieiga per internetą: $<$ http://css.snre.umich.edu/css_doc/CSS02-04.pdf>

Rodriguez-Fernandez, M. 2016. Social Responsibility and Financial Performance: The Role of Good Corporate Governance. Business Research Quarterly 19(2): 137-151. 
Rondinelli, D. A.; Berry, M. A. 2000. Environmental citizenship in multinational corporations: social responsibility and sustainable development. European Management Journal 18: 70-84.

Ruf, B. M., Muralidhar, K., Paul, K. 1998. The development of a systematic, aggregate measure of corporate social performance. Journal of Management 24(1): 119-133.

Saaty, T. L. 1994. How to Make a Decision: the Analytic Hierarchy Process. Interfaces 24(6): 19-43.

Saaty, T. L. 2001. Analytic Hierarchy Process. Encyclopedia of Operations Research \& Management Science. Editors - Gass, S. I.; Harris, C. M. 16-24.

Saaty, T. L. 2008. The Analytic Hierarchy and Analytic Network Measurement Processes: Applications to Decisions under Risk. European Journal of Pure and Applied Mathematics 1(1): 122-196.

Saaty, T. L.; Sagir, M. 2009. Extending the Measurement of Tangibles to Intangibles. International Journal of Information Technology \& Decision Making 8(1): 7-27.

Saether, K. T.; Ruth, V. A. 2008. Corporate Social Responsibility in a Comparative Perspective. The Oxford Handbook of Corporate Social Responsibility (PDF). Oxford: Oxford University Press, ISBN 0-19-921159-0.

Santoso, A. H.; Feliana, Y. K. 2014. The Association Between Corporate Social Responsibility and Corporate Financial Performance. Issues in Social \& Environmental Accounting 8(2): 82-103.

Savitz, A. W.; Weber, K. 2006. The Triple Bottom Line: How Today's Best-run Companies Are Achieving Economic, Social, and Environmental Success-and How You Can Too [žiūrèta 201511 29]. Prieiga per internetą: <http://web.a.ebscohost.com/ehost/ detail/detail?sid=f33f041a-8e22-4c6f-a55d-ab48a234f97c\%40sessionmgr4004\&vid=13 \&hid=4214\&bdata=JnNpdGU9ZWhvc3QtbG12ZQ\%3d\%3d\#db=nlebk\&AN=168158>

Savvidis, S.; Ginoglou, D. 2011. Environmental Indexes and Financial Ratios. Journal of Engineering Science \& Technology Review 4(3): 277-280.

Scalet, S.; Kelly, T. F. 2010. CSR Rating Agencies: What is Their Global Impact? Journal of Business Ethics 94(1): 69-88.

Scholtens, B. 2006. Finance as a Driver of Corporate Social Responsibility. Journal of Business Ethics 68(1): 19-33.

Searcy, C. 2012. Corporate Sustainability Performance Measurement Systems: a Review and Research Agenda. Journal of Business Ethics 107(3): 239-253.

SEB banko grupès finansinès ataskaitos [žiūrèta 201703 05]. Prieiga per internetą: $<$ https://www.seb.lt/apie-seb/investuotojams/finansine-informacija/seb-banko-grupesfinansines-ataskaitos>

Sharma, E. 2013. Measuring the Performance of Banks: An Application of AHP Model. Review of Management 3(3/4): 33-40. 
Shirley, Y. 2011. The Role of Banks in Corporate Social Responsibility. Journal of Applied Economics \& Business Research 1(2): 103-115.

Shnayder, L.; Rijnsoever, F. J.; Hekkert, M. P. 2015. Putting Your Money Where Your Mouth Is: Why Sustainability Reporting Based on the Triple Bottom Line Can Be Misleading, PLoS ONE 10(3): 1-23.

Slaper, T. F.; Hall, T. J. 2011. The Triple Bottom Line: What Is It and How Does It Work? Indiana Business Review 86(1): 4-8.

Spangenberg, J. H. 2002. Institutional sustainability indicators: an analysis of the institutions in Agenda 21 and a draft set of indicators for monitoring their effectivity. Sustainable development 10(2): 103-115.

Stankovič, J.; Popovič, Ž.; Kostevski, S. 2016. Determination of Expert Group Preferences in the Multi-Criteria Model for the Analysis of Local Economic Environment. Economic Themes 54(2): 261-280.

Stanujkic, D.; Dordevič, B.; Dordevič, M. 2013. Comparative Analysis of Some Prominent MCDM Methods: A Case of Ranking Serbian Banks. Serbian Journal of Management 8(2): 213-241.

Stein, E. W., Ahmad, N. 2009. Using the analytical hierarchy process (AHP) to construct a measure of the magnitude of consequences component of moral intensity. Journal of Business Ethics 89(3): 391-407.

Storebrand. 2015. Tvarumas [žiūrèta 201509 21]. Prieiga per internetą: <http://www. storebrand.lt/imones-socialine-atsakomybe/tvarumas/>

„Swedbank”, AB veiklos (finansinès) ataskaitos [žiūrèta 201703 05]. Prieiga per internetą: <https://www.swedbank.1t/lt/pages/358>

Šarkinas, R. 2008. Pasaulio finansų krizès pamokos Lietuvai. Pinigų studijos 2: 93-96. [žiūrèta 201703 05]. Prieiga per internetą: <http://www.lb.lt/sarkinas_3>

Šapalienè, L.; Valentukevičienè, S.; Zakarienė, J. 2014. Verslo plano ekonominių skaičiavimu pagrindai. Mokomoji knyga. Vilnius: UAB „Ciklonas“.

Šaparauskas, J.; Zavadskas, E. K.; Turskis, Z. 2011. Selection of facade's alternatives of commercial and public buildings on multiple criteria. International Journal of Strategic Property Management 15(2): 189-203.

Šimanskienè, L.; Kutkaitis, A. 2009b. Logistikos įmonių darni plètra panaudojant logistikos lygio indeksą (LPI). Management theory and studies for rural business and infrastructure development 19(4): 175-180.

Šimanskienè L.; Paužuolienè J. 2010. Corporate Social Responsibility Based on Sustainable Business. Human Resources: The Main Factor of Regional Development 3: 324-331. 
Šimanskienè, L.; Paužuolienè, J. 2011. Darnaus vystymo koncepcijos suvokimas organizacijoje. Management theory and studies for rural business and infrastructure development 2(26): 241-247.

Škare, M.; Golja, T. 2011. Corporate Social Responsibility and Corporate Financial Performance - is there a Link? Proceedings of the International Scientific Conference: 1521-1545.

The Economist. 2009. Triple bottom line [žiūrèta 201511 15]. Prieiga per internetą: <http://www.economist.com/node/14301663>

Torugsa, N. A.; O’Donohue, W., Hecker, R. 2012. Capabilities, Proactive CSR and Financial Performance in SMES: Empirical Evidence from an Australian Manufacturing Industry Sector. Journal of Business Ethics 109(4): 483-500.

Tschopp, D.; Nastanski, M. 2014. The Harmonization and Convergence of Corporate Social Responsibility Reporting Standards. Journal of Business Ethics 125(1): 147-162.

Turskis, Z. 2008. Multi-attribute Contractors Ranking Method by Applying Ordering of Feasible Alternatives of Solutions in Terms of Preferability Technique. Technological and Economic Development 14(2): 224-239.

Tvaronavičienè, M.; Ginevičius, R.; Grybaitè, V. 2008. Baltijos šalių išsivystymo palyginimas: praktiniai kompleksinio požiūrio taikymo aspektai. Verslas: teorija ir praktika (Business: Theory and Practice) 9(1): 51-64.

United Nations Global Compact. 2014. Guide to Corporate Sustainability [žiūrèta 2015 05 13]. Prieiga per internetą: <https://www.unglobalcompact.org/docs/ publications/ UN_Global_Compact_Guide_to_Corporate_Sustainability.pdf>

Unruh, G. 2008. Sustainable development vs. Sustainable redevelopment. Thunderbird International Business Review 50(1): 17-23.

Užšilaitytė, L.; Martinaitis, V. 2010. Search for Optional Solution of Public Building Renovation in Terms of Life Cycle. Journal of Environment Engineering and Landscape Management 18(2): 102-110.

Viešoji įstaiga LST Sert. LST EN ISO14001 [žiūrèta 201511 16]. Prieiga per internetą: <http://www.lstsert.lt/lstsert.php?pg=60>

Waddock, S. A.; Graves, S. B. 1997. The Corporate Social Performance - Financial Performance Link. Strategic Management Journal 18(4): 303-319.

Wang, Yu-Jie; Lee, Hsuan-Shih 2010. Evaluating Financial Performance of Taiwan Container Shipping Companies by Strength and Weakness Indices. International Journal of Computer Mathematics 87(1): 38-52.

Wu, H.-Y.; Tzeng, G.-H.; Chen, Y.-H. 2009. A fuzzy MCDM Approach for Evaluating Banking Performance Based on Balanced Scorecard. Expert Systems with Applications 36(6): 10135-10147. 
WWF Global. 2014. REPORT 2014: Environmental, Social and Governance: Integration for Banks: a Guide to Starting Implementation [žiūrèta 201601 08]. Prieiga per internetą: <http://wwf.panda.org/?226990>

Xiantao, L.; Wang, D. Jian, L. 2014. Empirical Analysis of the Correlation Between CSR of Petroleum Enterprises and Financial Peformances in China. Pakistan Journal of Statistics 30(5): 837-856.

Zavadskas, E. K.; Kaklauskas, A.; Turskis, Z.; Tamošaitienè, J. 2008. Selection of the effective dwelling house walls by applying attributes values determined at intervals. Journal of Civil Engineering and Management 14(2): 85-93.

Zavadskas, E. K.; Turskis, Z. 2011. Multiple Criteria Decision Making (MCDM) Methods in Economics: an Overview. Technological \& Economic Development of Economy 17(2): 397-427.

Zimmermann, H.-J. 2000. An Application-Oriented View of Modeling Uncertainty. European Journal of Operational Research 122(2): 190-198.

Zolfani, S. H.; Saparauskas, J. 2013. New Application of SWARA Method in Prioritizing Sustainability Assessment Indicators of Energy System. Engineering Economics 24(5): 408-414.

Žvirblis, A.; Zinkevičiūte, V. 2008. The Integrated Evaluation of the Macro Environment of Companies Providing Transport Services. Transport 23(3): 266-272. 


\section{Autorès mokslinių publikacijų disertacijos tema sąrašas}

\section{Recenzuojamuose mokslo žurnaluose}

Slapikaitè, I.; Tamošiūnienè, R. 2013. Socially Responsible Mutual Funds - A Profitable Way of Investing. Scientific Annals of the „Alexandru Ioan Cuza“ University of Iasi 60(1): 199-211.

Slapikaitè, I.; Tamošiūnienè, R. 2015a. Theoretical aspects of Corporate Social Responsibility as the Practical Implementation of Sustainable Development. Ekonomika A Management 4: 1-11.

Slapikaitè, I.; Tamošiūnienè, R.; Mackevičiūtė, K. 2015. Research of Investment Opportunities in Socially Responsible Business in Lithuania. Journal of Security and Sustainability 4(4): 621-632.

Slapikaitè, I.; Tamošiūnienè, R. 2017. Modeling a CSR Evaluation System. Transformation in Business \& Economics 16(1): 173-186.

Slapikaite, I. 2016. Practical Application of CSR Complex Evaluation System. Intellectual Economics 10(2): 101-107. 


\section{Straipsniai kituose leidiniuose}

Slapikaitè, I.; Tamošiūnienè, R. 2014. The Evolution and Trends of Socially Responsible Investing on Mutual Fund's Market. Unitech'2014 Gabrovo: International Scientific Conference 4: 82-90.

Slapikaitè, I.; Tamošiūnienè, R. 2015b. Development Trends of Socially Responsible Mutual Funds. CSR Trends. Beyond Business as Usual 151-169. 


\section{Summary in English}

\section{Introduction}

\section{Problem formulation}

Various economic, demographic and social changes, also climate changes, international and local regulations, standards and behaviour of the stakeholders - all of these subjects influence companies and their business environment. Funders, especially the commercial banks, being the core elements of the financial systems and the overall economy, can affect the companies mostly through their funding process. But the world's financial crisis, that occured less then 10 years ago has learnt some lessons - banks were trying to gain maximum profits very fast and were not paying enough attention to the sustainability when funding. Therefore, the portfolio of the new loans (for non-financial organisations and households) in Lithuania was growing extremely fast - from 2.3 mEUR in year 2005 up to 4.9 mEUR in 2006, accordingly profits of the biggest banks in Lithuania (i.e. „Swedbank“ AB and SEB bank) had grown more then twice from year 2005 to 2007 . Nevertheless, this growth was not sustainable and very soon, in year 2008, the above mentioned banks together with the whole banking industry started to assign large amounts of impairments for their funding portfolios - at that time the impairments compounded 9-10 percent from the overall funding portfolio (compared to 1 percent in year 2005-2007). Accordingly, profits have also decreased - the biggest loss the above mentioned banks have gained in year 2010 (0.3-0.4 mEUR). All these dramatic changes were like an indicator that financial industry does not go to the right direction. 
Today banks have to expand their attitude, especially when funding the companies. In order to ensure their financial stability, maintain the highest standards of safety and reliability, also to contribute to the sustainable economic and social development, banks have to apply a more holistic attitude in their activities. One of the best ways to achieve this and ensure the sustainable banking today is evaluation of corporate social responsibility (hereinafter - CSR) of the funding companies. But although the benefits the sustainable activity is obvious for many companies and banks as well, the biggest problem occurs when the banks try to evaluate CSR of the funding companies practically. The methods that are used now are rather limited and narrow - only a certain area of CSR is evaluated or even worse, only some separate criteria are evaluated when funding the companies. Moreover, the process is not complex and systematic.

The above mentioned issue may be caused by two related reasons. First of all, CSR from the funder's point of view is rather limited in scientific researches. Second, in order to evaluate CSR it is important to determine what exactly takes into account the concept of CSR from the funder's point of view. In order to solve all these issues, the problem of the present dissertation is formulated as follows: how to evaluate CSR from the funder's point of view.

\section{Relevance of the thesis}

After the world's financial crisis banks started concerning how to get back society 's trust and how to contribute to the sustainable economic and social development. In order to avoid such crisis in the future, banks were looking for various tools in order to manage the current situation, and that changed the overall philosophy in the banking industry for all the times (Lentner et al. 2015, Matei, Voica 2013). One of such tools was to pay a special attention to the sustainability of the bank. Financial stability ensured by better managed financials, ethics, transparent and more sustainable financial services - that was all that helped to ensure predictable, reliable activity of the banks and that enabled banks to represent the interests of the society in a much higher level. Also, it should be noticed that the banks have a good access to the society - they can do good by their own good practice, especially while funding the companies (Matei, Voica 2013, Lentner et al. 2015).

In order to ensure the sustainability it is important for the banks to be able to evaluate as much risks as it is possible. Moreover, today it is crucial to evaluate not only financial results of the funded companies but to take into account a more holistic view to evaluate social, environmental, ethical and governance aspects as well (Matei, Voica 2013). On the other hand, although this attitude has been applied actively for the last few years, evaluation of corporate social responsibility of the funded companies is still very patchy, with a lack of complexitiy and systematic. Improper or insufficient evaluation of CSR of the funded companies might cause not only risk underestimation but it might worsen the credit quality of the overall bank's loan portfolio, also worsen financial standing of the bank, increase risk of courts or even worsen bank's external rating $(\mathrm{Hu}$, Scholtens 2014). 


\section{Object of the research}

The doctoral dissertation explores corporate social responibility from the funder's point of view.

\section{Aim of the thesis}

The aim of the present dissertation is to create a complex evaluation system of corporate social responsibility for the funders, and to check it's applicability when evaluating the real companies.

\section{Objectives of the thesis}

1. To reveal the importance of CSR evaluation in the sustainable banking and economic development context.

2. To research the origins and causes of CSR, and its further historical genesis in the context of sustainable development.

3. To analyse today's concept of CSR, also to overview the criteria of corporate social responsibility applied by the different international and Lithuanian institutions.

4. After the research of evaluation methods of CSR, to form a theoretical background in order to create a complex evaluation system of CSR.

5. To construct an algorythm of CSR complex evaluation system and to apply it while practicaly forming a CSR complex evaluation system.

6. To test the applicability of the system while evaluating real companies ' CSR levels.

\section{Research methodolody}

In order to achieve the objectives defined in the present dissertation, a number of various methods were used. The first part was based on analytical research methodology: systematization, analysis and synthesis of scientific researches and other studies, generalisation of the key findings. In the second part, in order to construct an algorythm of CSR complex evaluation system and theorethically form a CSR complex evaluation system, there were used such methods: expert survey, generalisation and graphical representation of the systematized results. Also analysis and generalisation of different groups of criteria and multi-criteria desicion making methods that are further applied in order to create a CSR complex evaluation system. In the third part while practically forming a CSR complex evaluation system and testing its applicability practically there were used such methods: mathematical multi-criteria decision making methods (hereinafter - MCDM) - AHP, SAW, TOPSIS, VIKOR, VS, expert survey and assessment of its compatibility, generalisation of the key findings and insights. 


\section{Scientific noveltys of the thesis}

1. Determined the relation between corporate social responsibility and sustainable development concepts, formed the new economic success cycle and revealed the importance of CSR evaluation from the funder's point of view in the sustainble economic development context.

2. While forming a CSR complex evaluation system, suggested to integrate economic - financial criteria as the key group of criteria while evaluating CSR of the funded companies. Moreover, the system is characterized by complexity due to the different criteria groups and methods applied in it.

3. CSR complex evaluation system enables funders to evaluate CSR of the funded companies quantitatively, to better perceive risks, to allocate the resources more effectively, also to make more economically viable and sustainable decisions.

\section{Practical value of research findings}

The purpose of creating CSR complex evaluation system is to provide the recommendations for the funders on how to evaluate CSR of the funded companies more effectively, also to propose a tool for this - a CSR complex evaluation system. This tool will enable the funders to know their financed companies and understand their risks better, to manage and distribute bank's resources more effectively, to make more economcally viable and sustainable decisions that would lead to sustainable banking and help ensuring sustainable economic and social development.

CSR complex evaluation system is unique due to its complexitiy and applicability it can be used in order to evaluate CSR level of the certain companies in a 5-scale structure or to compare and rank several companies at once. Also, the system provides an opportunity to identify weaknesses and strenghts of the company 's CSR area and to perceive possible risks (i.e. while additionally doing a SWOT analysis).

\section{Statements to be defended}

1. Corporate social responsibility is one of the most important issues that needs to be taken into account by the funders when assessing the risk of the companies and making the decisions whether to fund them or not. Therefore, the evaluation of CSR of funded companies has to be complex, purposefully selecting and combining different groups of criteria: economic - financial, environmental, social and governance.

2. For the purpose of CSR evaluation, by applying multi-criteria desicion making methods purposefully and sequentially, the reliable CSR complex evaluation system can be constructed.

3. CSR complex evaluation system enables the funders to determine the CSR level of the funded company or some companies, to better perceive the risks, to distribute the resources more effectively and better manage credit risks. 
Proactive and sequential application of CSR complex evaluation system practically enables functioning of the economic success cycle.

\section{Approval of research findings}

7 scientific articles have been published on the topic of the present dissertation. Two articles were published in the scientific journals indexed by Web of Science (Slapikaite, Tamošiūnienè 2017), three indexed by Scopus (Slapikaitė, Tamošiūnienè 2013, Slapikaité, Tamošiūniené, Mackevičiūtè 2015, Slapikaitė 2016), one published in the monograph (Slapikaitè, Tamošiūnienè 2015b), one in peer-reviewed material of the international conference (Slapikaitè, Tamošiūnienè 2014) and one in scientific journal cited in other databases (Slapikaite, Tamošiūnienè 2015a). Also 3 presentations were made at international and Lithuanian conferences.

\section{Structure of the thesis}

Dissertation consists of the Introduction, three Chapters, Conclusions for each of the Chapter, General conclusions, References, List of publications and Annexes. The total volume of this paper is 119 pages, including 18 figures, 20 tables and 24 formulas. 192 sources were used as the reference for this dissertation.

\section{Theoretical aspects of evaluation of corporate social responsibility}

All the times financial institutions played the crucial role in the economy while attracting free capital and distributing the resources (funding). Less then 10 years ago the world's financial crisis has brought not only losses but some key lessons to learn for the future. Extremely growing loan portfolios later revealed that the banks were seeking for big profits within a too short period of time and they did not pay enough attention on risk concentration (Šarkinas 2008). Amount of new loans for non-financial corporations and households grew extremely fast - more then twice within one year (from $2.3 \mathrm{mEUR}$ in 2005 up to 4.9 mEUR in 2006) (Lithuanina Statistics Department). Another key problem was that the banks did not pay enough attention on risk management and sustainable lending (Šarkinas 2008). Therefore, soon the banks faced a big issue - a significant increase of impairment levels (from a usual 1 percent level up to 10 percent percent compared the total loan portfolio). This number shows that the banks had a real threat to loose such part of the portfolio and get into big financials problems like liquidity and solvency. Moreover, in order to get back the financial stability and trust of the society banks had to change their philoshophy and strategy essentially.

Later on, the XXIst century has brought for the financial sector a different - more holistic view. Banks started concentrating not only in maximizing their profits but also in managing their resources more effectively, better managing risks of the portfolio, more strict evaluation of the customers's risk, continuous improvement of the loan 
portfolio quality. So, CSR evaluation of funded companies was also one of the main ways in order to achieve sustainable banking goals.

Moreover, Lindgreen et al. (2009) stated that the integration of social and environmental aspects into daily activities of the company and interaction with the stakeholders cause new economic success model. According to Čiegis and Norkutė (2012) theory that the banks' activity has impact on every entity, it was suggested to develop the idea of economic success cycle further including: banks that are highly interested in companies" activities and financial standing and the state (government) that is highly interested in the activity of both companies and banks (Fig. S.1.1.).

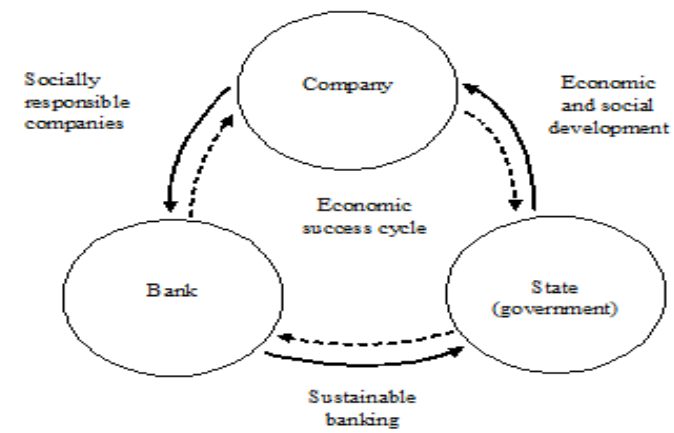

Fig. S.1.1. Corporate social responsibility and the cycle of economic success (source: author)

During the last few decades, the conpcept of corporate social responsibility has changed a lot. Generally, this genesis can be wraped into two main trends - first, that the reactive behaviour of the companies" had changed into proactiveness. Second, that the ideological image of corporate social responsibility changed into the necessity. Moreover, the concept of CSR has been developed and a new - more holistic concept called as sustainable development has appeared (Fig. S.1.2.).

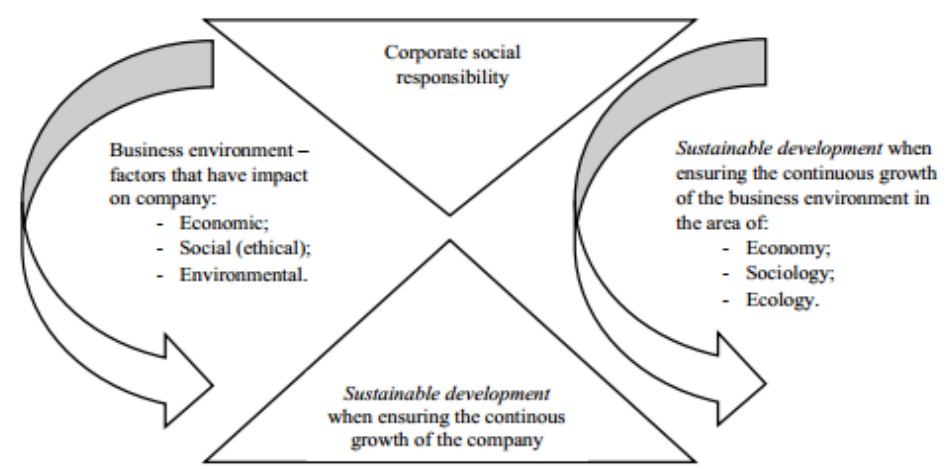

Fig. S.1.2. The relationship between corporate social responsibility and sustainable development (source: author) 
When analysing different scientific researches (Fongwa 2010, Goel 2010, Bernatonytė et al. 2009, Kleinaite 2007, Paužuolienè 2010), it was observed that the concept of sustainable development has two rather different interprerations that can be dinstinguished into: 1) sustainable development when ensuring the continuous growth of the company, and 2) sustainable development when ensuring the continous growth of the business environment in the areas of economy, sociology and ecology.

When analyzing the concept of corporate social responsibility, it is very often related to some criteria. But as there is no single understanding and explanation of what is corporate social responsibility, also there is now single criteria set that can be applied in all the cases. Generally, there exist some universally recognized sets of criteria mainly provided by the international and local institutions and standards but their contents are rather different. Despite this, there is one feature common for all the criteria sets usually they are qualitatively based and, therefore, hard to evaluate practically. According to this, most of the methods applied for evaluation of CSR are very qualitative: CSR is evaluated according to the benefits that are gained in the different areas of the the company's activity (Stanwick \& Stanwick 1998, Smith 1990, Gazzola 2012, Mathew and others), according to the benefits that gain stakeholders of the company (Fongwa 2010, Jurkaitis et al. 2011, Tschoppas and Nastanki 2014 and others), according to the benefits in the value chain process (Juščius, Jonikas 2013, Jonikas 2014) and according to the global - general attitute (Kagan et al. 2003, Dhiman 2008, Corina et al. 2009). Only the newest scientific researches investigates the evaluation of CSR based on quantitative based methods such as Analytic Hierarchy Process (AHP) method (Gutierrez et al. 2016), measuring profitability or return of investments (Chang et al. 2008).

The latest studies based on quantitative methods lead to the research of the relation between CSR and financial standing of the company. As many scientific studies (Dean 1998, Waddock, Graves 1997, Rodriguez-Fernandez 2016 and others) have proved that the higher CSR level causes better financial results, it was decided to include economic financial criteria as one of the most important group when evaluating CSR of the funded companies.

The analysis of all above mentioned scientific studies in the first chapter justify as assumption that there is not many studies that would consider the importance of CSR evaluation from the funder's point of view. Moreover, there are no studies observed that would suggest any method or tool for the funder in order to help assess CSR level of the funded companies.

Therefore, given that the corporate social responsibility is one of the key issues that has to be taken into account when evaluating the companies to be funded or not, the following chapter explores theoretical background and formation of CSR complex evaluation system.

\section{Theoretical modelling of corporate social responsibility complex evaluation system}

When forming CSR evaluation system, Juozaitiene (2007) recommends to use more simple criteria - variables and to minimize their number - then the evaluation system 
will be maximally understandable and not overloaded with redundant or even unnecessary information. Following this informal rule, the purpose was to prepre the simple set of CSR criteria for the interested parties to focus only on the key issues.

Therefore, while forming group of economic criteria, the main focus was on financial ratios, and the group was named as economic - financial group. Theoretical background was formed by the financial ratios that are the most important for the funders (according to Juozaitienė 2007, Antanavičienè and Šimelytė 2014, Elena 2012). Additionally, subgroup of profitability ratios was supplemented by the several important financial ratios, that were studied by Monea (2009), Kneževic et al. (2011), Kotane ir Kuzmina - Merlino (2012). Overall theoretical background for all the groups is detailed as follows (Table S. 2. 1).

Table S. 2. 1. Theoretical ground for CSR evaluation system (source: author)

\begin{tabular}{ll}
\hline $\begin{array}{l}\text { Group of } \\
\text { criteria }\end{array}$ & Theoretical background \\
\hline $\begin{array}{l}\text { Economic }- \\
\text { financial }\end{array}$ & $\begin{array}{l}\text { TBL theory by Elkington 1997; Goel 2010; Slaper, Hall 2011; } \\
\text { The economic-financial criteria base by Juozaitienė 2007; Antanavičienè, } \\
\text { Šmelytė 2014, Elena 2012; } \\
\text { Addition for profitability ratios by Monea (2009), Kneževic et al. (2011), } \\
\text { Kotane ir Kuzmina - Merlino (2012), Krivka ir Stonkute (2015), Wang ir } \\
\text { Lee (2010), Šapalienè } \text { et al. (2014) bei Daujotaite (2006); }\end{array}$ \\
\hline Environmental & $\begin{array}{l}\text { TBL theory by Elkington 1997; Goel 2010; Slaper, Hall 2011; } \\
\text { REPORT 2014: Environmental, Social and Governance: Integration for } \\
\text { Banks: a Guide to Starting Implementation. }\end{array}$ \\
\hline Social & $\begin{array}{l}\text { TBL theory by Elkington 1997; Goel 2010; Slaper, Hall 2011; } \\
\text { REPORT 2014: Environmental, Social and Governance: Integration for } \\
\text { Banks: a Guide to Starting Implementation. }\end{array}$ \\
\hline Governance & $\begin{array}{l}\text { REPORT 2014: Environmental, Social and Governance: Integration for } \\
\text { Banks: a Guide to Starting Implementation. }\end{array}$ \\
\hline
\end{tabular}

After theoretical background formation, relevant criteria that could be significant for CSR evaluation were determined (Table S. 2. 2.).

Table S. 2. 2. Relevant criteria for evaluating corporate social responsibility (source: author)

\begin{tabular}{|c|c|}
\hline Financial group of criteria & Social group of criteria \\
\hline $\begin{array}{l}\text { Profitability ratios: } \\
\text { 1. Gross margin; } \\
\text { 2. Net profit ratio (or Net income ratio); } \\
\text { 3. Operating profit ratio; } \\
\text { 4. EBITDA margin; } \\
\text { 5. ROA (Return on Assets); }\end{array}$ & $\begin{array}{l}\text { 22. Labour and worker rights, compliance } \\
\text { with labour standards and basic international } \\
\text { health and safety norms; } \\
\text { 23. Labour and community healt and safety, } \\
\text { that arise from customer satisfaction, or as a } \\
\text { result of the certain transaction (eg. }\end{array}$ \\
\hline
\end{tabular}


The end of Table S. 2.2

\begin{tabular}{|c|c|}
\hline Financial group of criteria & Social group of criteria \\
\hline $\begin{array}{l}\text { 6. ROE (Return on Equity); } \\
\text { 7. ROI (Return on Investment); } \\
\text { Liquidity ratios: } \\
\text { 8. Current ratio; } \\
\text { 9. Quick ratio (or Acid test ratio); } \\
\text { 10. Liquidation value; } \\
\text { Debt ratios: } \\
\text { 11. Debt to Total Assets; } \\
\text { 12. Debt to Equity; } \\
\text { 13. Debt to EBITDA; } \\
\text { 14. Interest Coverage; }\end{array}$ & $\begin{array}{l}\text { explosions); } \\
24 \text {. Consultation processes of the society and } \\
\text { inside the organization, and agreements on any } \\
\text { resettlement (physical or economic) that may be } \\
\text { required as a result of a transaction; } \\
\text { 25. Impact on local communities, indigenous } \\
\text { people, minorities, women and other vulnerable } \\
\text { groups; } \\
\text { 26. Impact on cultural and religious heritage } \\
\text { (including tangible and intangible heritage); }\end{array}$ \\
\hline Environmental group of criteria & Governance group of criteria \\
\hline $\begin{array}{l}\text { 15. Pollution and pollution abatement; } \\
\text { 16. Impacts on water quality and quantity } \\
\text { (where it affects various communities, } \\
\text { ecosystems), plus activities that have a high } \\
\text { water demand or occur in areas of water } \\
\text { shortage or uncertainty; } \\
\text { 17. Air emissions (including GHGs, } \\
\text { hazardous or toxic gases); } \\
\text { 18. Solid and other waste streams (hazardous } \\
\text { toxic materials, other harmful materials); } \\
\text { 19. Impacts of land-use change (loss of } \\
\text { biodiversity, impacts on natural habitats and } \\
\text { endangered species, GHG emissions); } \\
\text { 20. Resource use efficiency (use of energy, } \\
\text { water, reuse and recyling of other materials); } \\
21 \text {. Commitment to address ecosystem } \\
\text { service risks and issues (freshwater, climate } \\
\text { regulation, provision of food); }\end{array}$ & $\begin{array}{l}\text { 27. Corruption and bribery; } \\
\text { 28. Reputation; } \\
\text { 29. Management effectiveness. }\end{array}$ \\
\hline
\end{tabular}

When the set of criteria was formed, another important step was to evaluate each of the criteria and it's impact on CSR of the company. Therefore the weights of the criteria were counted. The aim of the overall system of criteria is to help identify the funded company's CSR level.

In the theoretical and practical studies, there are not so many weighting of CSR criteria. One of the possible reasons is that there are quite lots of local and international companies that present different sets of the criteria. As it was reviewed in the beginning of this study, set of criteria depends on various aspects - organization's activity, stakeholder's (or the user of the criteria) or what will be implemented by the criteria (i.e. to provide CSR reporting guidelines). Another reason is that it is complicated to measure qualitative data, especially to standardize with the specific formulas. However, researchers are looking for the ways how to measure CSR (Searcy 2012), and in the newest studies some are practically applying some quantitative methods - for example 
Gutierrez-Nieto et al. (2016) identified 26 criteria that collectively conclude credit scoring system. Each weighting of the criteria was counted by T. L. Saaty mathematical AHP method (Analitic Hierarchy Process method arba AHP). This mathematical method is widely used by Lithuanian researchers as well - Ginevičius, Podvezko 2008, Ginevičius et al. 2004, Rakauskienè, Tamošiūnienè 2013, Zavadskas, Turskis 2011, Tvaronavičienè et al. 2008. Though the method is mainly used for the quantitative primary data to be evaluated, however it is theoretically based on the qualitative data evaluation (Zavadskas, Turskis 2011, Saaty 1994). Therefore, according to the fact that the criteria in this research is hardly measured - based only on qualitative data, expert suvery was used as the most suitable for weighting the criteria. (Ginevičius 2006). In addition to the above-mentioned reasons, AHP method was appropriate due to: 1) set of criteria is combined by relatively big number of the criteria - totally 29 criteria, so, in this case, direct evaluation when each criteria can be weighted directly was not the most suitable (Ginevičius 2006); 2) the method allowed to compare every single pair of criteria and to weight each of it in respect of the overall CSR evaluation.

Nowadays multiple-criteria decision making (MCDM) methods are used in economics for solving various problems. Quite often MCDM methods are used together, therefore, one of the most discussed theoretical and practical questions was how to select properly the method that could be integrated into overall system of methods for solving the problem. While applying the methods, there was observed that each of the method has it's own advantages and disadvantages, and gives different results. Therefore, in order to minimize the influence of a certain MCDM methods to the final results, there was offered to use several of the methods together and afterwards to count the compatibility of the methods (Ginevičius, Podvezko2008). So, in addition to the above mentioned AHP method, there has been chosed to use these MCDM methods: TOPSIS, SAW, VIKOR and VS.

\section{Practical modeling and application of corporate social responsibility complex evaluation system}

The third chapter includes practical modeling of CSR complex evaluaton system that was developed by applying multi-criteria decision making methods. Further the applicability of the systems was practically tested by evaluating CSR of three real companies that operate in these industries: plastic, vehicles manufacturing, and oil production trade.

In order to practically model CSR complex evaluation system, weights for each of the 29 criteria in the system had to be assigned. For this purpose, there was formed an expert group - 9 professionals (managers, executives in the field of funding and evaluating CSR of the companies) from 4 biggest scandinavian banks in Lithuania. The professionals had to compare each pair of the criteria in the scale from 1 to 9 if the criteria in the matrix on the left is more important comparing to the one that is above in the horizontal line. The experts had to use such logics: 1 in the scale means that the importance level of both criteria is the same when evaluating CSR of the company, 3 means that the importance of the first criteria is slighty higher compared to its pair, 9 means that the importance of the first criteria is extremely higher compared to its pair. If 
vice versa (the second criteria is more important than the first one) - then the fractional number from scale $1 / 1$ to $1 / 9$ must be chosen. Method AHP was chosen as the most suitable for the bigger sets of criteria.

After all the comparisons were made and weights of criteria calculated, the hierarchy structure of Saaty $(1994,2008)$ was formed. The structure showed that economic - financial group of criteria is the most important (with the significance of 0.534) for the funders when evaluating CSR of the companies. This shows that even if the rest of the groups (environmental, social and governance) would have the highest evaluation for the certain company, it would not be enough that CSR level of the company could be stated as extremely high. From the economic - financial group of criteria debt ratio subgroup is the most important (0.617) compared to the rest of the subgroups (profitability and liquidity). Then debt to EBITDA ratio seems to be the most important (0.564) when evaluating CSR of the company. Liquidity and profitability sugroups of ratios are similarly significant when evaluating CSR of the company - with the significance meanings of 0.177 and 0.206 accordingly. In the profitability group of ratios the dominant ratios are: EBITDA margin (0.330), net profit ratio (0.124), operating profit ratio $(0.215)$ and $\mathrm{ROE}(0.127)$. In the liquidity group of ratios - quick ratio $(0.425)$.

Second important group of criteria after economic - financial group is governane (0.227) with the most significant criteria: corruption and bribery $(0.557)$ and reputation (0.360). Despite the fact, that governance group of criteria does not have an extremely high signifance, nevertheless, this group of criteria has to be in acceptable level when funding the company. From the social group of criteria $(0.135)$ the most important are labour and worker rights (0.306) and labour and community health and safety (0.412). From the environmental group of criteria the most important criteria are: pollution and pollution abatement (0.197), air emissions (0.186) and solid and other waste streams (0.204). IT has to be noticed that 11 the groups of criteria are closely related to each other (i.e. like the enironmental group can have an impact on eonomic - financial group or governance group), therefore, that is why CSR evaluation is suggested to be used as the system. Also, the weights of criteria support scientific findings that CSR is a very individual issue, mostly dependent on the individual needs of the certain company or at least industry.

Afterwards, the compatibility (the coefficient of concordance - Kendall's $W$ ) of the expert opinions was calculated according this formula:

$$
W=\frac{12 S_{k s}}{r^{2} n\left(n^{2}-1\right)},
$$

where $r$ is the number of experts; $n$ is the number of objects; $S_{k s}$ is the sum of the deviation of ranks from the mean.

Moreover, if the number of criteria is more then seven $(n>7)$, the significance of concordance coefficient can me calculated by using $\chi^{2}$ meaning (Podvezko 2005):

$$
\chi^{2}=W r(n-1) \frac{12 S_{k s}}{r n(n+1)} .
$$


If $\chi^{2}$ meaning is larger than critical value $\chi_{k r}^{2}$ from the table of $\chi^{2}$ distribution with $v=n-1$ degree of freedom and selected level of significance $\alpha$ (in this study $\alpha=0.05$ ), it means that the agreement of expert opinions is acceptable and the weights of criteria can be applied further (Podvezko 2005, Rakauskienè 2013) (Table S. 3. 1).

Table S. 3. 1. Calculation of $S_{k s}$, $W, \chi, \chi_{k r}$ meanings (source: author)

\begin{tabular}{lccccc}
\hline \multicolumn{2}{c}{ Criteria } & $S_{k s}$ & $W$ & $\chi^{2}$ & $\chi_{k r}$ \\
\hline $\begin{array}{l}\text { Economic }- \\
\text { financial } \\
\text { group }\end{array}$ & Profitability & 1307 & 0.58 & 31.12 & 12.59 \\
\cline { 2 - 6 } & Liquidity & 12.50 & 0.08 & 1.39 & 5.99 \\
\cline { 2 - 6 } & Debt service & 234 & 0.58 & 15.60 & 7.81 \\
\hline Environmental group & 1328 & 0.59 & 31.62 & 12.59 \\
\hline Social group & 587 & 0.72 & 26.09 & 9.49 \\
\hline \begin{tabular}{l} 
Governance group \\
\hline $\begin{array}{l}\text { Economic - finacial group of } \\
\text { criteria }\end{array}$
\end{tabular} & 134 & 0.83 & 14.89 & 5.99 \\
\hline All groups of criteria & 126 & 0.78 & 14 & 5.99 \\
\hline
\end{tabular}

According to Pridotkiene ir Pridotko (2012), expert opinion is agreed enough if concordance coefficient is equal (or exceeds) 0.6 meaning. From the calculations, it is obvious that liquidity subgroup of criteria cannot be applied further in the system due to extremely low $W(0.08)$. Therefore, it is suggested to eliminate this subgroup of criteria from the system, while other criteria can be applied further. Despite this, it is supposed that the quality of the system (that now concludes of 26 criteria) does not worsen in its uality because some of the information provided by liquidity ratios can be compensated by debt service ratio subgroup.

Afterwards the rest of the multi-criteria decision making methods (SAW, TOPSIS, VIKOR, VS) are used in order to compare some companies CSR level. Three companies that operate in different industries were evaluated in the Likert scale from 1 to 5 (with the meaning 1 that the company does not meet the certain criteria and 5 - if the company fully meets the criteria or, moreover, the case is involved in the startegic questions of the company). Then all the companies were ranked according to four different multi-criteria decision making methods (Table S. 3. 2).

Table S. 3. 2. Ranking of the companies according to MCDM methods when means of each criteria are not-normalized (source: author)

\begin{tabular}{llccc}
\hline & \multirow{2}{*}{ Method } & \multicolumn{3}{c}{ Company } \\
\cline { 3 - 5 } & & $\mathrm{A}$ & $\mathrm{B}$ & $\mathrm{C}$ \\
\hline \multirow{2}{*}{ SAW } & Meaning & 3.223 & 3.132 & 2.233 \\
\cline { 2 - 5 } & Rank & 1 & 2 & 3 \\
\hline
\end{tabular}


The end of Table S. 3.2

\begin{tabular}{|c|c|c|c|c|}
\hline & \multirow{2}{*}{ Method } & Company & Company & Company \\
\hline & & A & B & $\mathrm{C}$ \\
\hline \multirow{2}{*}{ TOPSIS } & Meaning & 0.612 & 0.431 & 0.063 \\
\hline & Rank & 1 & 2 & 3 \\
\hline \multirow{2}{*}{ VIKOR } & Meaning & 1.051 & 0.952 & 0.295 \\
\hline & Rank & 3 & 2 & 1 \\
\hline \multirow{2}{*}{ VS } & Meaning & 45.500 & 44.500 & 66.000 \\
\hline & Rank & 2 & 1 & 3 \\
\hline \multicolumn{2}{|c|}{ Average rank } & 1.75 & 1.75 & 2.5 \\
\hline \multicolumn{2}{|c|}{ Final rank } & $1-2$ & $1-2$ & 3 \\
\hline
\end{tabular}

The ranking was made in two ways - with normalized and not-normalized values. According to normalized values, TOPSIS method would has to be omited due the very low correlation coefficient meaning with the most of the multi-criteria decision making methods (correlation between SAW and TOPSIS methods was 0.14 , betwee VS and TOPSIS was 0.05). But in this case there is no normalization needed because all the criteria are only maximizing, therefore it is suggested to use for the system notnormalized criteria that includes all the methods.

Summarizing, the CSR complex evaluation system helps to rank the companies according to their CSR level - according to the application of the system practically, company A and B share 1st-2nd places and company $\mathrm{C}$ takes 3rd place. Also, the system (specifically SAW method) helps to identify CSR level according to the suggested 5 scale systems - as the practical application of the system shows, companies A and B exceed the average level of CSR (taken that the average is 2.5 out of maximum 5), and company $\mathrm{C}$ does not reach the average of CSR level. Of course, banks can further make their own ,cut-off's" according to their credit risk appetite and loan portfolio structure.

An appropriate evaluation of funded companies' CSR helps to know customer and understand its risk profile better, to manage bank's loan portfolio and resources more effectively - all of these benefits lead to the better quality of the bank's loan portfolio. Better quality of loan portfolio leads to decrease of impairments for the loans and banks can afford to keep less unemployed capital (resources). All of these things helps to improve banks financial ratios (like liquidity, capital efficiency, profitability) that in turn enables banks to be more sustainable and reliable to the society. Moreover, sustainable banking then leads the economic success cycle to run.

\section{General conclusions}

1. The analysis of scientific literature and the consequences of world's financial crisis revealed the importance of CSR evaluation from the funder's point of view. It was determined that in order to maintain high standards of reliability 
and safety for the banks, to improve credit quality of the loan portfolio, to manage resources more effectively and to contribute to the social and economic development, it has to be paid much more attention to the field of sustainability. Consistent evaluation of CSR of the funded companies today is one of the key moments when aiming the sustainable banking and seeking to ensure the functioning of the economic success cycle. Therefore, it is very important for the funders to have an appropriate tool for the CSR evaluation.

2. According to the scientific literature analysis, scienticts have agreed that CSR is actually an individual issue for every organization and the limited quantitative methods for evaluating CSR have created favorable conditions for creating a unique CSR complex evaluation system. Additionally to that, there has been made a research in order to determine the maturity level of commercial banks in the field of social responsibility with the assumption made that the higher is maturity level, the more bank is willing to integrate social responsibility principles into its activity. The assumption was approved.

3. Based on J. Elkington's Triple bottom line theory and other scientific researches, there has been made a theorethical background for the further formation of CSR complex evaluation system. There has been identified the most possibly important criteria that were further grouped into four groups: economic - financial, environmental, social and governance. Different groups of criteria that define complexity and versatility of the system were later used for the purpose of creating CSR complex evaluation system.

4. For the purpose of setting the weights for each of the criteria in the system, AHP method was used. As AHP method is based on the expert survey, the compatibility meanings (Kendall's $W$ ) of the expert opinions was calculated. The results showed that due to the low compatibility meaning (0.08) the liquidity subgroup has to be eliminated from the economic - financial group of criteria and accordingly from the overall system. The final CSR complex evaluation system then concluded by 26 criteria. Other acceptable compatibility meanings (that range from $W=0.58$ to $W=0.83$ ) for the rest of the criteria revealed the potential of further scientific researches in the field of financial criteria (ratios) and CSR relation and it revealed the specifics of the banks operating in Lithuania - the sustainability level of the banks might rather vary among the banks.

5. The constructed CSR complex evaluation system enabled to test its applicability while evaluating three companies that operate in different industries. The relevancy of other four multi-criteria decisions making methods (SAW, TOPSIS, VIKOR and VS) for the system was tested by calculating the correlation between each pair of the methods. As all the criteria in the system were maximizing, there was no need to use the normalized meanings that excludes TOPSIS method. Therefore, it was decided to use the full, package ' of methods. CSR complex evaluation system has revealed futher opportunities of practical applicability: 
5.1. Separately used SAW method enables funders (banks) to determine the CSR level of the funded company or companies in the suggested 5-scale structure. It would enable the funder to manage the credit risk more reliable and effectively.

5.2. The methods (SAW, TOPSIS, VIKOR and VS) used all together enables to compare (rank) several companies in the field of CSR. That would accordingly help for the funder to make the funding decifions more efficiently and to manage the banks resources more effectively.

5.3. Additionally to the system, by applying SWOT analysis, it enables to broaden the analysis of the funded companies: to better perceive the risks and to foresee additional opportunities and use it as a competitive advantage when cooperating with the funded companies. 



\section{Priedai $^{3}$}
A priedas. Detalizuota finansinių kriterijų grupé
B priedas. Komercinių bankų socialinès atsakomybès brandumo lygių struktūra
C priedas. Komercinių bankų Lietuvoje brandumo lygio nustatymas
D priedas. Detalizuoti sistemos kriterijai
E priedas. Sistemos kriterijų reikšmingumo nustatymas ekspertinio vertinimo būdu
F priedas. Kriterijų reikšmingumų nustatymo pavyzdys
G priedas. Kriterijų reikšmingumų skaičiavimas pagal AHP metodą
H priedas. Sistemos praktinis pritaikymas
I priedas. Trijų i̇monių socialinès atsakomybès daugiakriterinio vertinimo skaičiavimai
Y priedas. Ekspertinio vertinimo duomenų rangavimas
J priedas. Disertacijos autoriaus sąžiningumo deklaracija
K priedas. Bendraatorių sutikimai teikti publikacijų medžiagą disertacijoje
L priedas. Autorès mokslinių publikacijų disertacijos tema kopijos

${ }^{3}$ Priedai pateikiami pridètoje kompaktinèje plokštelëje. 
Indrè SLAPIKAITÉ

IMONIŲ SOCIALINÉS ATSAKOMYBĖS

VERTINIMAS FINANSUOTOJO

POŽIŪRIU

Daktaro disertacija

Socialiniai mokslai, ekonomika (04S)

EVALUATION OF CORPORATE

SOCIAL RESPONSIBILITY FROM

THE FUNDER'S POINT OF VIEW

Doctoral dissertation

Social sciences,

Economics (04s)

201705 08, 11,5 sp, I, Tiražas 20 egz,

Vilniaus Gedimino technikos universiteto

leidykla „Technika“,

Saulètekio al, 11, 10223 Vilnius,

http://leidykla,vgtu, It

Spausdino UAB „BMK leidykla"

$\mathrm{J}$, Jasinskio g, 16, 01112 Vilnius 